\title{
Documentation of the Unsaturated-Zone Flow (UZF1) Package for Modeling Unsaturated Flow Between the Land Surface and the Water Table with MODFLOW-2005
}

Chapter 19 of

Section A, Ground Water, of

Book 6, Modeling Techniques
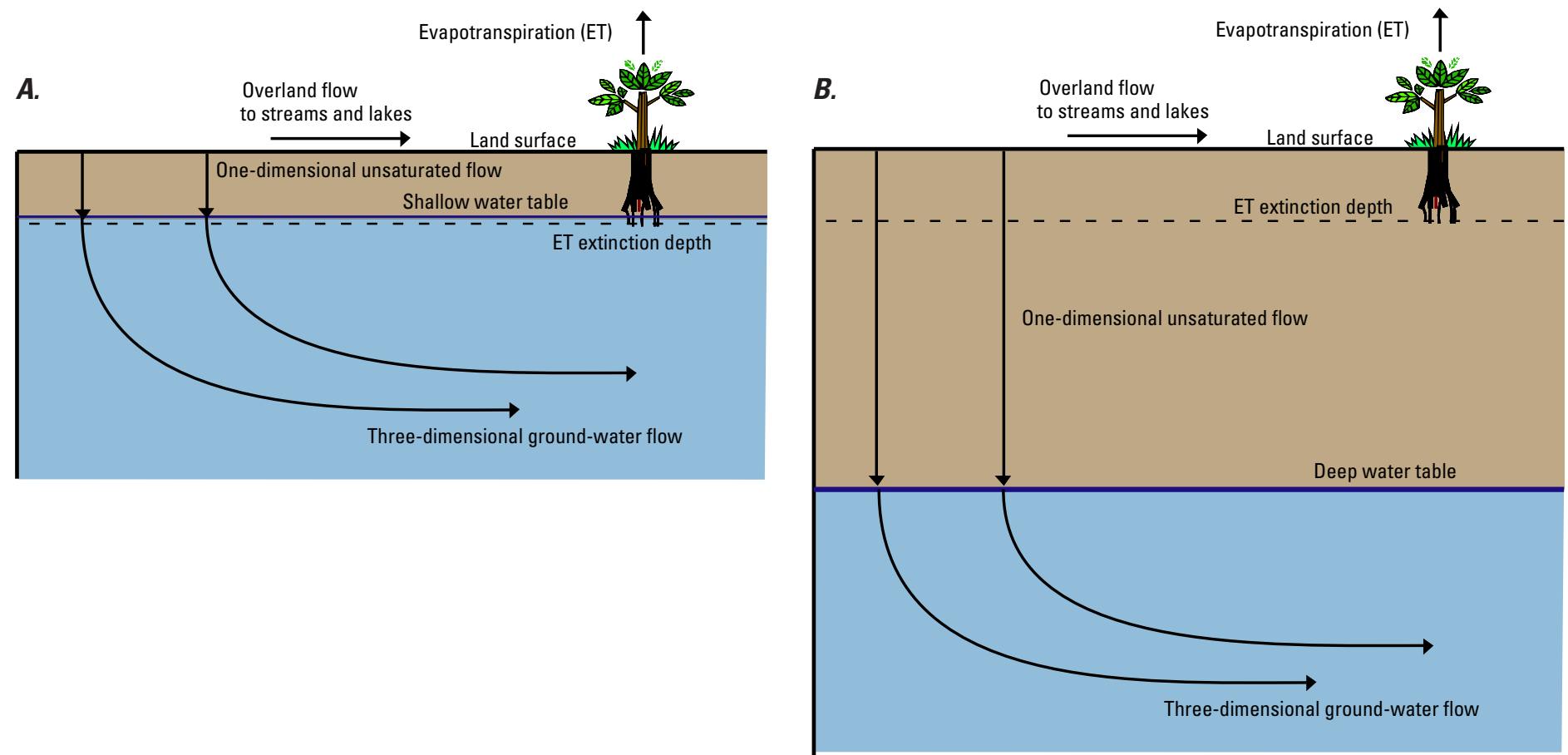

Techniques and Methods 6-A19

U.S. Department of the Interior

U.S. Geological Survey 


\section{Documentation of the Unsaturated-Zone Flow (UZF1) Package for Modeling Unsaturated Flow Between the Land Surface and the Water Table with MODFLOW-2005}

By Richard G. Niswonger, David E. Prudic, and R. Steven Regan

Chapter 19 of

Section A, Ground Water, of

Book 6, Modeling Techniques

Techniques and Methods 6-A19 


\title{
U.S. Department of the Interior \\ Gale A. Norton, Secretary \\ U.S. Geological Survey \\ P. Patrick Leahy, Acting Director
}

\section{U.S. Geological Survey, Reston, Virginia: 2006}

\author{
For sale by U.S. Geological Survey, Information Services \\ Box 25286, Denver Federal Center \\ Denver, CO 80225 \\ For more information about the USGS and its products: \\ Telephone: 1-888-ASK-USGS \\ World Wide Web: http://www.usgs.gov/
}

\begin{abstract}
Any use of trade, product, or firm names in this publication is for descriptive purposes only and does not imply endorsement by the U.S. Government.

Although this report is in the public domain, permission must be secured from the individual copyright owners to reproduce any copyrighted materials contained within this report.
\end{abstract}

Suggested citation:

Niswonger, R.G., Prudic, D.E., and Regan, R.S., 2006, Documentation of the Unsaturated-Zone Flow (UZF1) Package for modeling unsaturated flow between the land surface and the water table with MODFLOW-2005: U.S. Geological Survey Techniques and Methods 6-A19, 62 p. 


\section{PREFACE}

A new Unsaturated-Zone Flow (UZF1) Package was written for use with the U.S. Geological Survey (USGS) MODFLOW-2005 ground-water model. The UZF1 Package is designed to simulate percolation through an unsaturated zone between land surface and the water table. The performance of this computer program has been tested in models of hypothetical ground-water flow systems; however, future applications of the programs may reveal errors that were not detected in the test simulations. Users are requested to notify the USGS if errors are found in the documentation report or in the computer program. Correspondence regarding the report or program should be sent to:

U.S. Geological Survey, WRD 2730 North Deer Run Road Carson City, Nevada 89701

Attention: Richard G. Niswonger or David E. Prudic

Although the computer program has been written and used by the USGS, no warranty, expressed or implied, is made by the USGS or the United States Government as to the accuracy and functionality of the program and related program material. Nor shall the fact of distribution constitute any such warranty, and no responsibility is assumed by the USGS in connection therewith.

MODFLOW-2005, the UZF1 Package, and other ground-water programs are available from the USGS at the following World Wide Web (WWW) address:

http://water.usgs.gov/software/ground water.html 


\section{Contents}

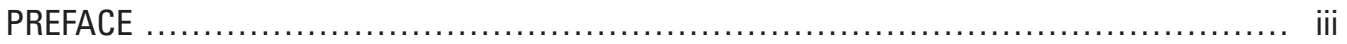

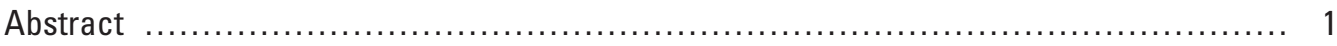

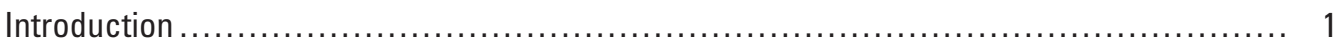

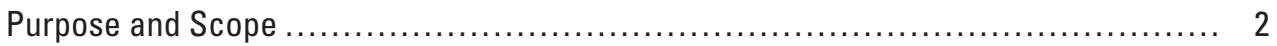

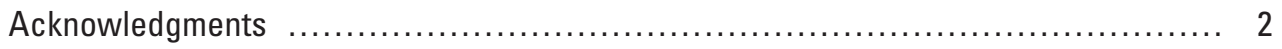

Theory and Conceptualization of Unsaturated-Zone Flow $\ldots \ldots \ldots \ldots \ldots \ldots \ldots \ldots \ldots \ldots \ldots \ldots$

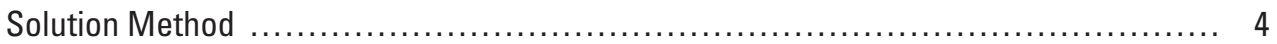

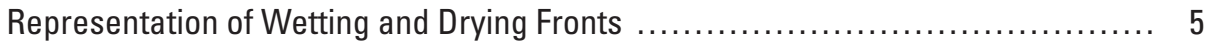

ET in the Unsaturated Zone ............................................... 7

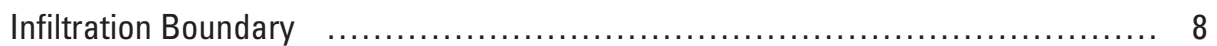

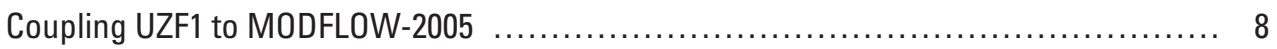

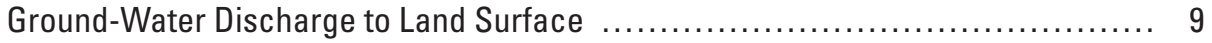

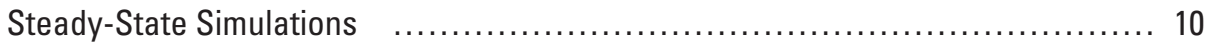

Assumptions and Limitations .................................................... 10

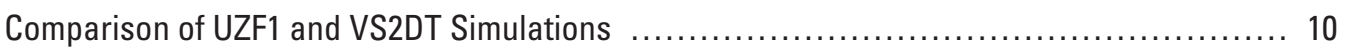

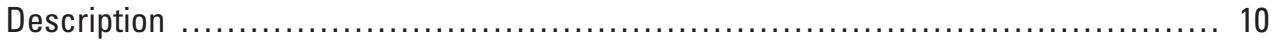

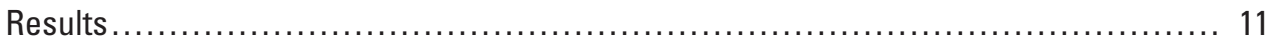

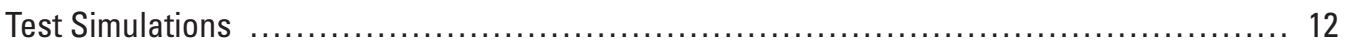

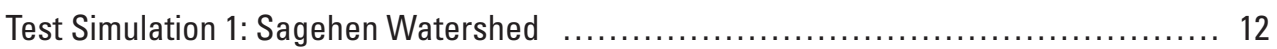

Test Simulation 2: Simple Hypothetical Problem .................................. 20

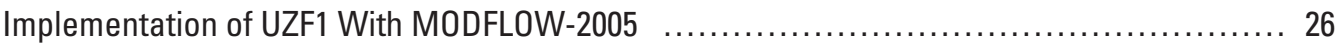

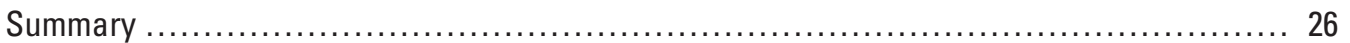

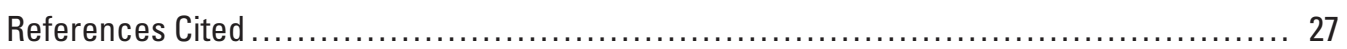

Appendix 1: Data Input Instructions for the Unsaturated-Zone Flow (UZF1) Package $\ldots . \ldots . .29$

Appendix 2: Selected Input Datasets and Printed Results for Test Simulation $2 \quad \ldots \ldots \ldots \ldots \ldots 33$

\section{Figures}

Figure 1. Diagram showing one-dimensional unsaturated-zone flow coupled to three-dimensional ground-water flow

Figure 2. Diagram showing a wetting front moving through a uniform column of unsaturated material affected by a decrease in surface flux, and results from a kinematic-wave solution of the wetting front represented by leading and trailing waves

Figure 3. Graph showing kinematic-wave approximation of a wetting front moving through a uniform column of unsaturated material affected by a constant evapotranspiration rate of 4.35 millimeters per day

Figure 4. Graphs showing comparison of results from the kinematic-wave approximation used to simulate unsaturated flow (UZF1) with a two-dimensional finite-difference solution of Richards' equation (VS2DT; Healy, 1990) assuming evapotranspiration demand rates of: $(A) 5 \times 10-8$ meter per second, $(B) 5 \times 10-7$ meter per second, and $(C) 1 \times 10-6$ meter per second 


\section{Figures-Continued}

Figure 5. Map showing distribution of hydraulic conductivity from ground-water

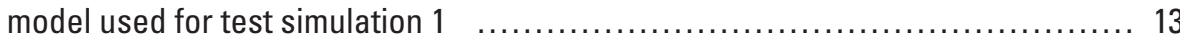

Figure 6. Map showing distribution of steady-state ground-water depths used for test simulation 1

Figure 7. Graph showing infiltration rate and evapotranspiration demand used for test

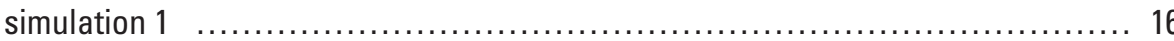

Figure 8. Map showing distribution of infiltration factors used for test simulation $1 \quad \ldots \ldots \ldots 17$

Figure 9. Graph showing volumetric rates of infiltration, recharge, and evapotranspiration summed over the model domain for test simulation $1 \quad \ldots \ldots \ldots 18$

Figure 10. Graph showing streamflow at the basin outlet, ground-water discharge to land surface plus saturation excess, and ground-water discharge to

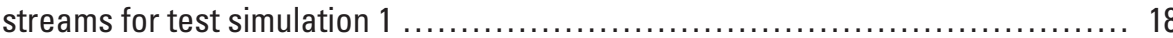

Figure 11. Maps showing distribution of ground-water seepage to land surface for $(A)$ steady state, and $(B)$ July 1.

Figure 12. Graph showing water-content profiles in the unsaturated zone of a model cell located in an upland area (column 9, row 36) at selected dates for test simulation 1

Figure 13. Diagram showing well locations, elevation of top of consolidated rocks beneath basin-fill aquifer, and distribution of hydraulic conductivity and specific yield of the basin-fill aquifer used in test simulation 2

Figure 14. Diagram showing hypothetical basin-fill aquifer with model grid, land-surface contours, active cells, and stream segment and reach numbering for test simulation 2

\section{Tables}

Table 1. Unsaturated zone variables used in comparison of results from the Unsaturated-Zone Flow (UZF1) Package in MODFLOW-2005 with those from the Variably-Saturated Two-Dimensional Flow and Transport (VS2DT)

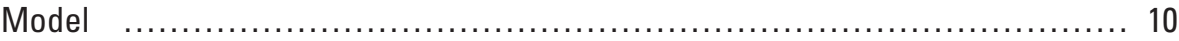

Table 2. MODFLOW-2005 Packages and files used for test simulation $1 \quad \ldots \ldots \ldots \ldots \ldots \ldots$

Table 3. Hydraulic properties and other selected variables used in the Layer-Property Flow (LPF) and the Unsaturated-Zone Flow (UZF1) Packages for test simulation 1

Table 4. Method for calculating stream depth and width, inflow rates, streambed properties, stream dimensions, and Manning's roughness coefficients for stream segments used in test simulation 2

Table 6. Hydraulic properties and other selected variables used in the Layer-Property Flow (LPF) and Unsaturated-Zone Flow (UZF1) Packages for test simulation 2

Table 5. Specified infiltration and pumping rates for the 12 stress periods used in test simulation 2

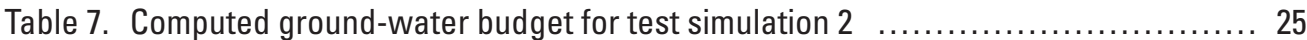

Table 8. Computed unsaturated-zone budget for test simulation $2 \ldots \ldots \ldots \ldots \ldots \ldots \ldots \ldots \ldots \ldots \ldots \ldots \ldots \ldots \ldots$ 


\section{Conversion Factors, Datums, and Acronyms}

Conversion Factors

\begin{tabular}{lcl}
\hline Multiply & By & To obtain \\
\hline cubic centimeter $\left(\mathrm{cm}^{3}\right)$ & 0.06102 & cubic inch $\left(\mathrm{in}^{3}\right)$ \\
cubic meter $\left(\mathrm{m}^{3}\right)$ & 264.2 & gallon $(\mathrm{gal})$ \\
cubic meter $\left(\mathrm{m}^{3}\right)$ & 35.31 & cubic foot $\left(\mathrm{ft}^{3}\right)$ \\
cubic meter per day $\left(\mathrm{m}^{3} / \mathrm{d}\right)$ & 35.31 & cubic foot per day $\left(\mathrm{ft}^{3} / \mathrm{d}\right)$ \\
cubic meter per second $\left(\mathrm{m}^{3} / \mathrm{s}\right)$ & 35.31 & cubic foot per second $\left(\mathrm{ft}^{3} / \mathrm{s}\right)$ \\
cubic meter per year $\left(\mathrm{m}^{3} / \mathrm{yr}\right)$ & .000811 & acre-foot per year $(\mathrm{acre}-\mathrm{ft} / \mathrm{yr})$ \\
kilometer $(\mathrm{km})$ & .6214 & mile $(\mathrm{mi})$ \\
meter $(\mathrm{m})$ & 3.281 & foot $(\mathrm{ft})$ \\
meter per day $(\mathrm{m} / \mathrm{d})$ & 3.281 & foot per day $(\mathrm{ft} / \mathrm{d})$ \\
meter per second $(\mathrm{m} / \mathrm{s})$ & 3.281 & foot per second $(\mathrm{ft} / \mathrm{s})$ \\
millimeter $(\mathrm{mm})$ & .03937 & inch $(\mathrm{in})$. \\
square kilometer $\left(\mathrm{km}^{2}\right)$ & 247.1 & acre \\
square kilometer $\left(\mathrm{km}^{2}\right)$ & .3861 & square mile $\left(\mathrm{mi}^{2}\right)$ \\
square meter $\left(\mathrm{m}^{2}\right)$ & .0002471 & acre \\
square meter $\left(\mathrm{m}^{2}\right)$ & 10.76 & square foot $\left(\mathrm{ft}^{2}\right)$ \\
\hline
\end{tabular}

Datums

Vertical coordinate information is referenced to the North American Vertical Datum of 1988 (NAVD 88).

Horizontal coordinate information is referenced to the North American Datum of 1983 (NAD 83).

Altitude, as used in this report, refers to distance above the vertical datum.

Acronyms

\begin{tabular}{ll}
\hline Acronyms & Meaning \\
\hline BCF & Block-Centered Flow \\
ET & evapotranspiration \\
GWF & Ground-Water Flow \\
LPF & Layer-Property Flow \\
MODFLOW & modular finite-difference ground-water flow model \\
SFR2 & Streamflow-Routing \\
SIP & Strongly Implicit Procedure \\
USGS & U.S. Geological Survey \\
UZF1 & Unsaturated-Zone Flow \\
VSF & Variably-Saturated Flow \\
VS2DT & Variably-Saturated Two-Dimensional Flow and Transport Model \\
\hline
\end{tabular}




\title{
Documentation of the Unsaturated-Zone Flow (UZF1) Package for Modeling Unsaturated Flow Between the Land Surface and the Water Table with MODFLOW-2005
}

\author{
By Richard G. Niswonger, David E. Prudic, and R. Steven Regan
}

\section{Abstract}

Percolation of precipitation through unsaturated zones is important for recharge of ground water. Rain and snowmelt at land surface are partitioned into different pathways including runoff, infiltration, evapotranspiration, unsaturated-zone storage, and recharge. A new package for MODFLOW2005 called the Unsaturated-Zone Flow (UZF1) Package was developed to simulate water flow and storage in the unsaturated zone and to partition flow into evapotranspiration and recharge. The package also accounts for land surface runoff to streams and lakes.

A kinematic wave approximation to Richards' equation is solved by the method of characteristics to simulate vertical unsaturated flow. The approach assumes that unsaturated flow occurs in response to gravity potential gradients only and ignores negative potential gradients; the approach further assumes uniform hydraulic properties in the unsaturated zone for each vertical column of model cells. The Brooks-Corey function is used to define the relation between unsaturated hydraulic conductivity and water content. Variables used by the UZF1 Package include initial and saturated water contents, saturated vertical hydraulic conductivity, and an exponent in the Brooks-Corey function. Residual water content is calculated internally by the UZF1 Package on the basis of the difference between saturated water content and specific yield.

The UZF1 Package is a substitution for the Recharge and Evapotranspiration Packages of MODFLOW-2005. The UZF1 Package differs from the Recharge Package in that an infiltration rate is applied at land surface instead of a specified recharge rate directly to ground water. The applied infiltration rate is further limited by the saturated vertical hydraulic conductivity. The UZF1 Package differs from the Evapotranspiration Package in that evapotranspiration losses are first removed from the unsaturated zone above the evapotranspiration extinction depth, and if the demand is not met, water can be removed directly from ground water whenever the depth to ground water is less than the extinction depth. The UZF1 Package also differs from the Evapotranspiration Package in that water is discharged directly to land surface whenever the altitude of the water table exceeds land surface. Water that is discharged to land surface, as well as applied infiltration in excess of the saturated vertical hydraulic conductivity, may be routed directly as inflow to specified streams or lakes if these packages are active; otherwise, this water is removed from the model.

The UZF1 Package was tested against the U.S. Geological Survey's Variably-Saturated Two-Dimensional Flow and Transport Model for a vertical unsaturated flow problem that includes evapotranspiration losses. This report also includes an example in which MODFLOW-2005 with the UZF1 Package was used to simulate a realistic surfacewater/ground-water flow problem that includes time and space variable infiltration, evapotranspiration, runoff, and groundwater discharge to land surface and to streams. Another simpler problem is presented so that the user may use the input files as templates for new problems and to verify proper code installation.

\section{Introduction}

Historically, hydrologic processes that occur near the land surface, such as infiltration and evapotranspiration (ET) have been modeled separately from regional ground-water flow processes. Watershed-runoff models simulate near-surface hydrology and non-physically-based shallow unconfined ground-water flow, but rarely simulate physically-based threedimensional regional ground-water flow. Similarly, regional ground-water modeling studies often simplify near-surface hydrologic processes such that recharge is specified to the model on the basis of external calculations independent of ground-water levels. Recently, however, regional ground-water flow models have been coupled to watershed-runoff models (Sophocleous and Perkins, 2000). Coupled models are used to simulate the effects of near-surface hydrology on regional ground-water flow by partitioning precipitation into various pathways among the atmosphere, surface, and subsurface. In this manner, recharge in regional ground-water models can be simulated in concert with changing climate. Moreover, ground-water flow and watershed-runoff modeling is improved by more realistically including the effects of ground-water seepage to land surface and streams, and by simulating the rejection of infiltration caused by high ground-water levels. 
Modeling flow through the unsaturated zone has been a major obstacle to coupling watershed-runoff and regional ground-water flow models. One approach is to use Richards' equation to model both saturated and unsaturated flow (Freeze, 1971). Richards' equation is highly non-linear and more difficult to solve than the conventional ground-water flow equation. Models that incorporate Richards' equation require much finer spatial grids and time steps, which limits their applicability for simulating regional ground-water flow problems. Additionally, modeling both saturated and unsaturated flow with the numerical solution of Richards' equation requires that unsaturated flow be simulated in three dimensions, which is often unnecessary for basinscale applications because the direction of unsaturated flow averaged over large grid cells is usually vertical (Mantoglou, 1992; Chen and others, 1994).

Another approach to coupling regional ground-water flow models to watershed-runoff models is to simulate unsaturated flow using Richards' equation in only one dimension and three-dimensional ground-water flow. This approach has been used to model unsaturated flow over large areas (Pikul and others, 1974) and to develop the integrated surface-water and ground-water flow model MIKESHE (Refsgaard and Storm, 1995). The approach used by Pikul and others (1974) and Refsgaard and Storm (1995) is similar to the approach used in developing the Unsaturated-Zone Flow (UZF1) Package for MODFLOW-2005, which solves the three-dimensional ground-water flow equation using finite-difference techniques (Harbaugh, 2005; fig. 1). The one-dimensional form of Richards' equation is approximated by a kinematic-wave equation that is solved by the method of characteristics (Smith, 1983). The method of characteristics solution for unsaturated flow precludes the need to develop a structured grid of the unsaturated zone for numerical stability and simplifies handling of the moving boundary defined by the interface between the water table and unsaturated zone.

\section{Purpose and Scope}

This report presents a new package for simulating vertical unsaturated flow in MODFLOW-2005 (Harbaugh, 2005). The package is intended to provide an efficient means of simulating recharge in MODFLOW-2005 that considers the effects of flow, ET, and storage in the unsaturated zone; it is also intended to be used for coupling MODFLOW to precipitation-runoff models. The theoretical development of the kinematic-wave approximation to Richards' equation and the method of characteristic solution was presented by Smith (1983) and Smith and Hebbert (1983). The method of characteristics solution for unsaturated flow is extended in this report to consider ET losses. The method was initially incorporated with MODFLOW-2000 through the simulation of unsaturated flow beneath intermittent streams without considering ET (Niswonger and Prudic, 2004).
This report also describes how the UZF1 Package is coupled to MODFLOW-2005 and how the UZF1 Package calculates ground-water seepage to land surface. A comparison is presented between MODFLOW-2005 using the UZF1 Package and the U.S. Geological Survey (USGS) VariablySaturated Two-Dimensional Flow and Transport Model (VS2DT; Healy, 1990) for a simple problem that involves vertical unsaturated flow with ET. Two test simulations also are described: the first test simulation shows results from a transient model of a $27 \mathrm{~km}^{2}$ watershed in which infiltration, ET, and ground-water discharge vary through time. The second test simulation is a simple problem that can be used to verify proper code installation and as a template for setting up new problems.

A more complex method for simulating flow through the unsaturated zone is available for MODFLOW-2000. The Variably-Saturated Flow (VSF) Process (Thoms and others, 2006) uses a finite-difference approximation to solve the threedimensional form of Richards' equation. VSF replaces the standard Ground-Water Flow (GWF) Process in MODFLOW2000 (Harbaugh and others, 2000). The process is designed for problems where horizontal flow within the unsaturated zone is important. VSF includes packages that can simulate seepage faces, infiltration with ponding, bare soil evaporation, and plant transpiration. The VSF Process offers a more rigorous and more computationally demanding treatment of flow through the unsaturated zone than that provided by the UZF1 Package.

\section{Acknowledgments}

The U.S. Geological Survey Ground-Water Resources Program and the Office of Ground Water funded this work. The original idea to develop the UZF1 Package for MODFLOW began in the summer of 1995 and was inspired by interest in coupling MODFLOW to a precipitation-runoff model. The development of this work began with many conversations with Jon P. Fenske and Arlen D. Feldman (retired) of the Army Corps of Engineers Hydrologic Engineering Center, Davis, California, and with Stanley A. Leake and Richard W. Healy of the U.S. Geological Survey. The Hydrologic Engineering Center provided the initial support to develop a plan for incorporating precipitation runoff models with MODFLOW (Fenske and Prudic, 1998). The authors are grateful to Steven L. Markstrom of the U.S. Geological Survey National Research Program for his help in the final design of UZF1, and the technical reviewers of this report, including Paul M. Barlow, Randall T. Hanson, Arlen W. Harbaugh, Devin L. Galloway, and Richard W. Healy of the U.S. Geological Survey. 

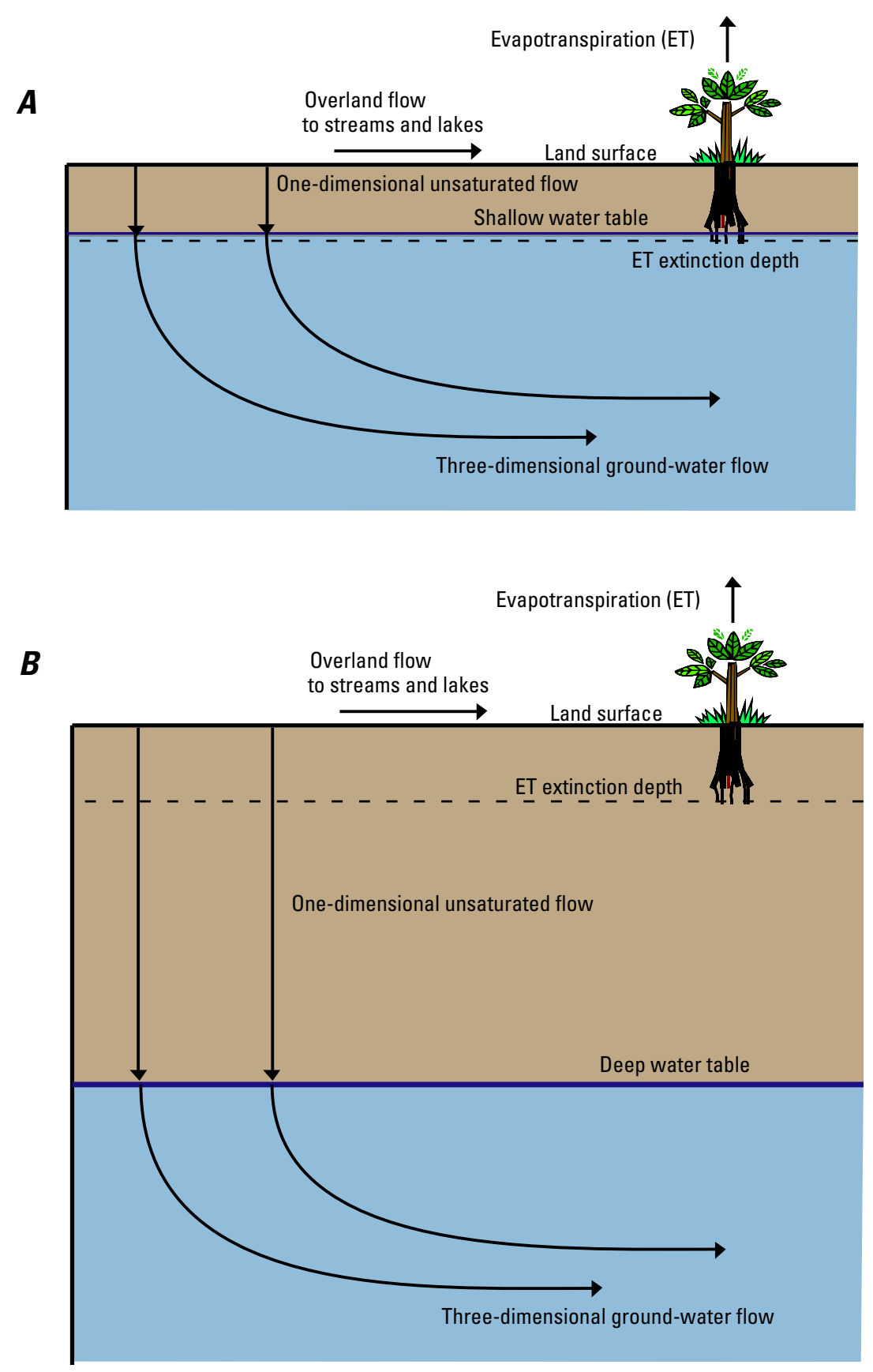

Figure 1. One-dimensional unsaturated-zone flow coupled to three-dimensional ground-water flow. 


\section{Theory and Conceptualization of Unsaturated-Zone Flow}

Vertical flow through a homogeneous unsaturated zone can be approximated with kinematic waves (Colbeck, 1972; Smith, 1983; Smith and Hebbert, 1983; Charbeneau, 1984). This approximation is made by simplifying Richards' equation, which can be written in the vertical dimension as:

$$
\frac{\partial \theta}{\partial t}=\frac{\partial q}{\partial z}-i=\frac{\partial}{\partial z}\left[D(\theta) \frac{\partial \theta}{\partial z}-K(\theta)\right]-i
$$

where

$\theta$ is the volumetric water content (volume of water per volume of rock);

$q$ is the water flux (volume of water per time per unit area);

$z$ is the elevation in the vertical direction (length);

$D(\theta)$ is the hydraulic diffusivity (length squared per time);

$K(\theta)$ is the unsaturated hydraulic conductivity as a function of water content (length per time);

$i$ is the ET rate per unit depth (length per time per

$t$ is time. length); and

If equation 1 is simplified to remove the diffusive term, assuming that the vertical flux is only driven by gravitational forces, the vertical flux owing to gravity is:

$$
q=-K(\theta)
$$

where

$q$ is shown as negative downward.

Substituting equation 2 into equation 1, neglecting $D(\theta) \frac{\partial \theta}{\partial z}$ (the diffusive term), and assuming evaporation is removed from the soil profile instantaneously and all flow is downward vertical yields:

$$
\frac{\partial \theta}{\partial t}+\frac{\partial K(\theta)}{\partial z}+i=0
$$

\section{Solution Method}

The method of characteristics solution to equation 3 is obtained by rewriting equation 3 so that $\theta$ is taken partially in terms of $t$ and $z$ :

$$
\frac{\partial \theta}{\partial t}+\frac{\partial K(\theta)}{\partial \theta} \frac{\partial \theta}{\partial z}=-i
$$

and by introducing the equation of variation (Abbott, 1966):

$$
\frac{\partial \theta}{\partial t} d t+\frac{\partial \theta}{\partial z} d z=d \theta
$$

Equations 4 and 5 written in matrix form yields:

$$
\left[\begin{array}{cc}
1 & \frac{\partial K(\theta)}{\partial \theta} \\
d t & d z
\end{array}\right]\left[\begin{array}{l}
\frac{\partial \theta}{\partial t} \\
\frac{\partial \theta}{\partial z}
\end{array}\right]=\left[\begin{array}{c}
-i \\
d \theta
\end{array}\right] .
$$

$\partial \theta / \partial t$ and $\partial \theta / \partial z$ must be indeterminate along characteristic lines (Abbott, 1966). This occurs only when the determinant of the coefficient matrix in equation 6 and the determinants of the matrices obtained by substituting the right hand side vector for each column in the coefficient matrix are all zero, as described in equation 7 :

$$
\left|\begin{array}{cc}
1 & \frac{\partial K(\theta)}{\partial \theta} \\
d t & d z
\end{array}\right|=0,
$$

$$
\left|\begin{array}{cc}
1 & -i \\
d t & d \theta
\end{array}\right|=0
$$

$$
\left|\begin{array}{cc}
-i & \frac{\partial K(\theta)}{\partial \theta} \\
d \theta & d z
\end{array}\right|=0 .
$$

Expanding the determinants yields:

$$
\begin{gathered}
\frac{d z}{d t}=\frac{\partial K(\theta)}{\partial \theta}=v(\theta), \\
\frac{d \theta}{d t}=-i, \\
\frac{d \theta}{d z}=\frac{-i}{v(\theta)},
\end{gathered}
$$

where

$v(\theta)$ is the characteristic velocity restricted to the downward (positive $z$ ) direction (length per time) and $\theta$ decreases according to the ET rate along a characteristic path. 
The characteristic equations $8 \mathrm{a}, \mathrm{b}$, and c define the velocity of a wave, the change in water content of the wave with time, and the change in water content with depth behind the wave, respectively. This wave represents a wetting front in the unsaturated zone that was generated by a sudden increase in infiltration at land surface and that is being affected by ET. Without ET, the water content of the wave is constant over the wave profile. However, the inclusion of ET creates a non-linear slope $\left(\frac{d \theta}{d z}\right)$ in water content over the wave profile if a non-linear function for $K(\theta)$ is used, such as the Brooks-Corey function (Brooks and Corey, 1966).

The derivative $\frac{\partial K(\theta)}{\partial \theta}$ is discontinuous over a sharp wetting front that results from neglecting the diffusive term in equation 1, such that the spatial derivative in equation 3 is not defined in the absence of hydraulic diffusion. An analytic solution for the velocity may still be derived by considering the effects of diffusion and substituting an equivalent sharp wetting front of equal mass (Smith, 1983; Charbeneau, 1984). The solution to equation 1 for a wetting front that considers hydraulic diffusion can be found by integrating over a control volume containing a single wetting front (Charbeneau, 1984):

$$
\frac{d}{d t} \int_{z_{1}}^{z_{2}} \theta d z+\left(K(\theta)-D(\theta) \frac{\partial \theta}{\partial z}\right) \mid \begin{aligned}
& z_{2} \\
& z_{1}
\end{aligned}=0
$$

where

$z_{1}$ and $z_{2}$ are points above and below the wetting front at distances far enough that $\frac{\partial \theta}{\partial z} \approx 0$, respectively.

$D(\theta)$ can be neglected because $\frac{\partial \theta}{\partial z} \approx 0$ at $z_{1}$ and $z_{2}$ such that:

$$
\frac{d}{d t} \int_{z_{1}}^{z_{2}} \theta d z+K\left(\theta_{2}\right)-K\left(\theta_{1}\right)=0,
$$

where

$$
K\left(\theta_{1}\right) \text { and } K\left(\theta_{2}\right) \text { are the values of } K(\theta) \text { at depths } z_{1} \text { and } z_{2} \text {. }
$$

Integrating over a profile containing a sharp front with equivalent mass gives:

$$
\int_{z_{1}}^{z_{2}} \theta d z=\theta_{1}\left(z_{f}-z_{1}\right)+\theta_{2}\left(z_{2}-z_{f}\right),
$$

where

$z_{f}$ is the depth of the sharp front.

Combining equations 10 and 11 gives:

$$
\frac{d z_{f}}{d t}=u_{s}\left(\theta_{1}, \theta_{2}\right)=\frac{K\left(\theta_{1}\right)-K\left(\theta_{2}\right)}{\theta_{1}-\theta_{2}},
$$

where

$u_{s}$ is the velocity of a sharp wetting front (length per time);

$\theta_{1}$ is the volumetric water content above a depth $z_{f}$; and

$\theta_{2}$ is the volumetric water content below a depth $z_{f}$.

\section{Representation of Wetting and Drying Fronts}

An increase in the infiltration rate will cause a wetting front to form, which is represented by a lead wave. A decrease in the infiltration rate will cause a drying front to occur, which is represented by a trailing wave. Thus, waves are used to represent both wetting and drying fronts. Attenuation of a lead wave occurs as a trailing wave of higher velocity overtakes it. When a trailing wave overtakes a lead wave, the water content of the lead wave becomes equal to the water content of the trailing wave. Consequently, this reduces the velocity of the lead wave. Conversely, when a lead wave overtakes a trailing wave or another lead wave of lower velocity, the overtaken wave is removed, and the water content and flux of the uppermost lead wave are maintained, resulting in rewetting. The process of waves intercepting each other is termed a shock, and this process is important to the method of characteristics because wave properties, such as water content and flux, become discontinuous at the instant a shock occurs (Abbott, 1966).

In contrast to a wetting front that stays sharp, trailing waves elongate with time owing to gravity. Consequently, trailing waves must be divided into a series of incremental waves or be represented by a function that describes internal drainage with time. In either case, internal drainage is determined based on the water content and relative location of points along a trailing wave. For example, points $A$ and $B$ shown in figure 2 represent two points along the trailing wave where the velocities may be determined. The velocity at points $A$ and $B$ is calculated from the characteristic solution (equation $8 \mathrm{a}$ ) and the ratio of their velocities is equal to the ratio of their depths:

$$
\frac{z_{B}}{z_{A}}=\frac{u\left(\theta_{B}\right)}{u\left(\theta_{A}\right)}=\frac{d K(\theta) /\left.d \theta\right|_{\theta=\theta_{B}}}{d K(\theta) /\left.d \theta\right|_{\theta=\theta_{A}}},
$$

where 
$z_{A}$ is the depth of the trailing wave increment below land surface represented by point $A$ in figure 2 , and

$z_{B}$ is the depth of trailing wave increment below land surface represented by point $B$ in figure 2 .

In contrast to a lead wave that forms a discontinuity in the water content profile, the derivative $\partial K(\theta) / \partial \theta$ is continuous over a trailing front. Accordingly, the BrooksCorey unsaturated hydraulic conductivity function can be used to evaluate $\partial K(\theta) / \partial \theta$. The Brooks-Corey function for unsaturated hydraulic conductivity can be expressed as:

$$
K(\theta)=K_{s}\left[\frac{\theta-\theta_{r}}{\theta_{s}-\theta_{r}}\right]^{\varepsilon},
$$

where

$K_{s}$ is the saturated hydraulic conductivity;

$\theta_{r}$ is the residual water content;

$\theta_{s}$ is the saturated water content; and

$\varepsilon$ is the Brooks-Corey exponent.

\section{WATER CONTENT $(\theta)$}

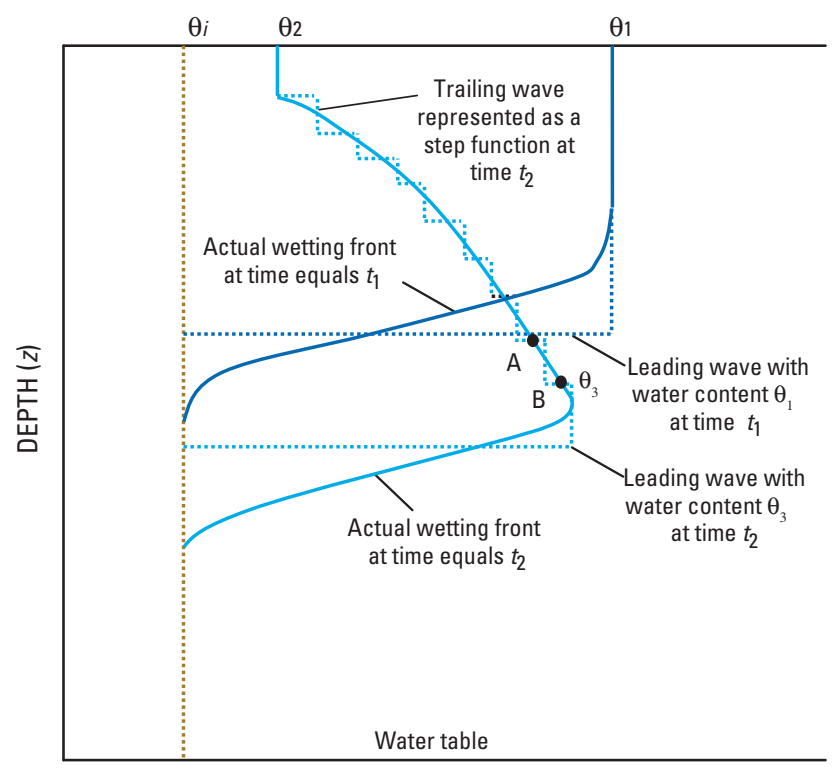

Figure 2. A wetting front moving through a uniform column of unsaturated material affected by a decrease in surface flux, and results from a kinematic-wave solution of the wetting front represented by leading and trailing waves.

(Modified from Smith and Hebbert, 1983.)
The drainable water from an unconfined or water-table aquifer, referred to as the specific yield or $S_{y}$, is equal to the porosity minus the specific retention $\left(S_{r}\right)$, where $S_{r}$ is the volume of water per unit volume of rock that is retained when the rock is drained by gravity (Meinzer, 1923, p. 28). Specific yield is used by MODFLOW-2005 to calculate the amount of storage within an unconfined aquifer. Thus, continuity between the unsaturated zone and unconfined aquifers in MODFLOW-2005 is maintained through the specific yield by approximating $S_{r}$ with $\theta_{r}$, and $S_{y}$ with $\theta_{s}-\theta_{r}$. Residual water content generally is smaller than $S_{r}$, such that caution should be used when representing unsaturated flow parameters in the UZF1 Package with measured values.

The velocity of the deepest point along a trailing wave is determined by taking the derivative of equation 14 with respect to $\theta$ :

$$
v(\theta)=\frac{\varepsilon K_{s}}{S_{y}}\left[\frac{\theta-\theta_{r}}{S_{y}}\right]^{\varepsilon-1},
$$

where

$v$ and $\theta$ are the velocity and water content, respectively, at the deepest point along a trailing wave.

A relation between the deepest point along a trailing wave and all other points along a trailing wave is determined by substituting the velocity defined by equation 15 into equation 13 and results in:

$$
z(\theta)=z_{0}\left[\frac{\theta-\theta_{r}}{\theta_{0}-\theta_{r}}\right]^{\varepsilon-1},
$$

where

$$
\begin{aligned}
& z(\theta) \text { is the depth of a point on a trailing wave; } \\
& \theta \text { is the water content of a point on a trailing wave; and } \\
& \theta_{0} \text { and } z_{0} \text { are the water content and depth of the deepest } \\
& \text { point along a trailing wave, respectively. }
\end{aligned}
$$

For example, the depths of points along a trailing wave may be generated by choosing water content values between $\theta_{2}$ and $\theta_{3}$ shown in figure 2 and by using equation 16 to calculate the depth at a particular time following a decrease in the infiltration rate. Thus, equation 15 may be used to calculate the velocity and the corresponding depth of the front of a trailing wave and then equation 16 can be used to determine the drainage profile above the trailing front.

During a pulse of infiltration, a lead wave's velocity and water content will decay during a subsequent period of less infiltration as trailing waves overcome the lead wave. The spreading of a trailing wave caused by gravity is defined by equations 15 and 16; however, these equations are not 
applicable after a trailing wave has intercepted a lead wave. Analytic relations can be derived for routing trailing waves during interception with a lead wave but these equations are difficult to solve. A simpler approach is to divide the trailing wave into steps or increments and calculate velocities of each increment based on a finite-difference approximation (Smith, 1983):

$$
v=\frac{K(\theta)-K(\theta-\Delta \theta)}{\Delta \theta},
$$

where

$\Delta \theta$ is the change in water content between two adjacent locations along a trailing wave.

The UZF1 Package relies on equations 15 and 16 to route trailing waves until the trailing waves intercept another lead wave, at which point the trailing wave is discretized into multiple waves that are routed according to equation 17.

The finite-difference approximation of the true trailing wave as depicted in figure 2 does not conserve mass perfectly when a trailing wave intercepts a lead wave and vice versa. However, for problems involving rapidly varying infiltration rates, mass is conserved within an error of less than 0.05 percent when each trailing wave is represented by 15 increments, although 10 increments are sufficient for most problems to achieve a mass balance error of less than 0.05 percent. The user specifies the number of increments used to represent a trailing wave with the UZF1 Package input parameter NSTRAIL.

As described, waves are generated by changes in the infiltration rate and will have differing velocities leading to the possibility of shocks. Determination of the timing of shocks is required for modeling because the wave properties $(v, \theta)$ become discontinuous in time and have to be recalculated in order to continue the solution. Thus, the UZF1 Package routinely calculates the shortest time for any two waves to intersect. Waves are routed continuously between wave intersections, while wave properties remain constant. Consequently, the UZF1 Package requires a unique time discretization that is specific to the problem being solved; the UZF1 Package time steps are different than those used in MODFLOW-2005.

\section{ET in the Unsaturated Zone}

Evaporation and uptake by roots in the unsaturated zone can cause negative potential gradients, such that diffusive forces can be important. Evaporation can cause water to move upward in the unsaturated zone by drying out the soil at land surface. These conditions cannot be modeled with kinematic waves because diffusive forces are neglected. However, infiltrating water affected by evaporation and uptake by roots can be approximated with kinematic waves during relatively wet conditions because negative potential gradients are less important. This approach assumes that evaporation and uptake by roots can be grouped together as ET, and that they occur as an instantaneous loss of water over a depth interval equal to the depth of root uptake.

Assuming that $i$ is independent of $\theta$, equations $8 \mathrm{~b}$ and $8 \mathrm{c}$ can be integrated to find:

$$
\begin{gathered}
\theta_{\tau+t}=\theta_{\tau}-i t, \\
z_{2}=\frac{\left[K\left(\theta_{2}\right)-K\left(\theta_{1}\right)\right]-i z_{1}}{-i},
\end{gathered}
$$

where

$\theta_{\tau}$ is the water content at the head of a lead wave above the ET extinction depth after time $\tau$, and

$\theta_{\tau+t}$ is the water content at the head of a lead wave after time $\tau+t$ subject to the ET rate per unit depth $i$.

ET is specified as a rate (length per time) within the UZF1 Package (input variable PET) and is converted internally to a rate per unit depth by dividing the specified ET rate by the extinction depth (EXTDP).

Equation 18a is used to calculate the water content at the head of a lead wave through time and equation $18 \mathrm{~b}$ is used to calculate the depth of points along the leading-wave profile between $\theta=\theta_{q}$ and $\theta=\theta_{\tau+t}$, where $\theta_{q}$ is the water content at land surface corresponding to the infiltration rate $q$, and $\theta_{1}$ and $\theta_{2}$ are the water contents at arbitrary points along the lead-wave profile with $\theta_{2}$ being deeper than $\theta_{1}$ (fig. 3 ). The water content of a trailing wave is decreased according to the ET rate and equation 18a. If the water table elevation is above the extinction depth and the ET demand is not met by the unsaturated zone, then ET is removed directly from ground water. ET is removed from ground water using the same method implemented in the MODFLOW ET Package (McDonald and Harbaugh, 1988, p. 10-1).

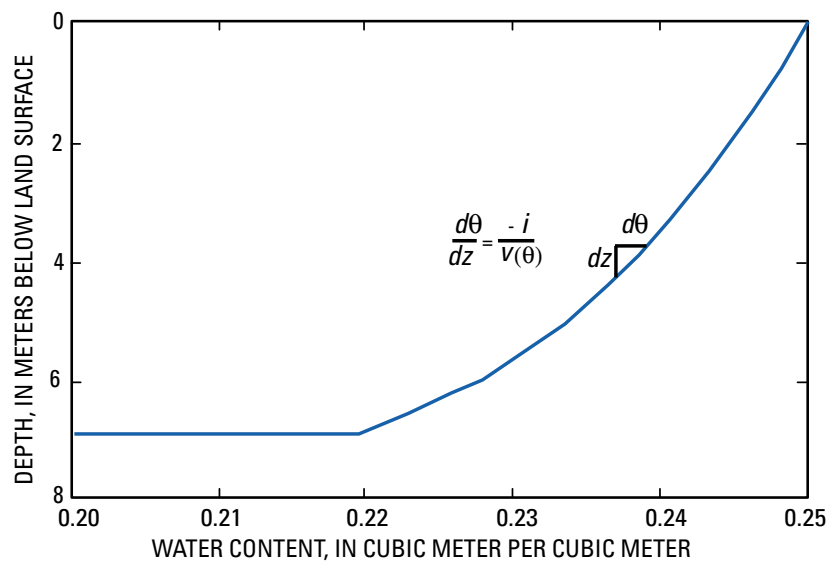

Figure 3. Kinematic-wave approximation of a wetting front moving through a uniform column of unsaturated material affected by a constant evapotranspiration rate of 4.35 millimeters per day. 


\section{Infiltration Boundary}

The specified infiltration rate is converted to water content in order to apply the characteristic solutions for unsaturated flow. A relation between water content and infiltration rate can be determined assuming the flux is equal to the unsaturated hydraulic conductivity using equations 2 and 14 (Charbeneau, 1984):

$$
\begin{gathered}
\theta=\left(\frac{q_{i n}}{K_{s}}\right)^{1 / \varepsilon}\left(S_{y}\right)+\theta_{r} \quad 0<q_{i n} \leq K_{s}, \\
\theta=\theta_{s} \quad K_{s}<q_{i n},
\end{gathered}
$$

where

$$
\begin{gathered}
\theta \text { is the water content of a wave generated from } \\
\text { infiltration, and } \\
q_{i n} \text { is the infiltration rate (length per time). }
\end{gathered}
$$

The water content is set to the saturated water content when the infiltration rate specified in the UZF1 Package input file exceeds the saturated vertical hydraulic conductivity. If the specified infiltration rate is greater than the saturated vertical hydraulic conductivity, then the difference is multiplied by the model cell plan-view area and this volumetric rate of water can be added to a user-specified stream reach or lake by setting the UZF1 Package variable IRUNF LG to greater than zero. Equation 19 ignores the time to ponding and infiltration rates that exceed the saturated vertical hydraulic conductivity (Smith and Parlange, 1978).

An algorithm was written in FORTRAN using equations $12,14,15,16,17,18$ and 19 to simulate vertical unsaturated flow and ET. This algorithm keeps track of the location, water content, velocity, and flux of all waves in the unsaturated zone through time and the interaction of waves overtaking one another. Additionally, changes in the thickness of the unsaturated zone owing to changes in the elevation of the water table are considered with respect to waves reaching the water table and contributing to ground-water storage.

\section{Coupling UZF1 to MODFLOW-2005}

Flow from the unsaturated zone as recharge to the water table in an unconfined aquifer is subtracted from the right-hand side of the system of equations that are solved by MODFLOW-2005:

$$
A X=B-Q_{\mathrm{UZF} 1},
$$

where

$A$ is a matrix containing the coefficients of the conductance equations ( $\mathrm{HCOF}$ array) that are solved by MODFLOW-2005;

$X$ is a one-dimensional vector containing the groundwater heads that are solved by MODFLOW-2005;

$B$ is a one-dimensional vector containing all known terms in the conductance equations that are not multiplied by unknown head values (RHS array); and

$Q_{U Z F 1}$ is the volumetric rate (volume per time) of recharge computed in a given model cell from the UZF1 Package.

Recharge that is simulated using the UZF1 Package is dependent on the water table elevation (ground-water head). Thus, the UZF1 Package is coupled to MODFLOW-2005 within the iteration loop. However, because ground-water recharge is dependent on the amount of storage and the downward flux rate in the unsaturated zone, there is no general equation that defines the relation between recharge and ground-water head, such as the conductance equation in the Streamflow-Routing (SFR1) Package (Prudic and others, 2004). Recharge from the UZF1 Package does not affect the HCOF array.

Based on the test simulations presented in this report, the UZF1 Package does not cause additional instabilities or slow convergence of MODFLOW-2005 when ground water is not discharging to land surface. Ground-water levels that rise above land surface add an additional head dependency when using the UZF1 Package owing to the calculation of ground-water discharge to land surface, and consequently, convergence may be slowed significantly when ground water is discharging to land surface from many model cells. MODFLOW-2005 simulations using the UZF1 Package may increase simulation time compared to using the Recharge Package owing to the additional calculations required to simulate flow through the unsaturated zone.

An infiltration rate at land surface (length per time) is specified for each vertical column in the active model domain (appendix 1). The infiltration rate is multiplied by the planview area of the cell to produce a volumetric flow rate (volume per time). Three options are used in the UZF1 Package to determine where flow in the unsaturated zone recharges ground water (UZF1 variable NUZTOP). The three options are those used in the Recharge Package (McDonald and Harbaugh, 1988, p. 7-6; Harbaugh and others, 2000, p. 67-68). The first option specifies that all recharge is to the top model layer only; the second option allows for recharge to be specified for a particular layer in each vertical column; and the third option allows for recharge to the uppermost active cell 
in a vertical column. When the last option is used in the UZF1 Package, the program will continue to route water through the unsaturated zone until it reaches the water table of the uppermost active cell. However, the hydraulic properties of the unsaturated zone will remain constant even if the unsaturated zone spans more than one cell in the vertical direction. If there are no active cells in a column beneath land surface, then infiltration and recharge do not occur and a warning statement is printed to the output file. If a cell becomes active during a simulation and the corresponding element in the UZF1 array IUZFBND is nonzero, then infiltration and recharge will start to occur.

As stated previously, mass balance is achieved by approximating the residual water content variable with the specific retention computed as the saturated water content minus the specific yield. Thus, if the water table rises into the unsaturated zone, the aquifer will yield an amount of water equal to the water table rise multiplied by the difference between the water content and the specific retention. Alternately, if the water table falls due to ground-water discharge or pumping at some other location, then the water content in the unsaturated zone between the old and new water table is set equal to the specific retention.

Recharge occurring during a rising water table over a time step is calculated by first routing waves through the unsaturated zone using the base of the unsaturated zone as the water-table elevation at the end of the previous time step. Flow across the base is accumulated for the time step and the volume of water in the unsaturated zone through which the water table rose over the time step is added to the volume that flowed past the base. This sum is divided by the time step to obtain a volumetric recharge rate. Once the flow equation has been solved for the time step, a new base of the unsaturated zone in each active cell is computed. Recharge occurring during a declining water table is computed based on the flux of water from the unsaturated zone during the time step using the base of the unsaturated zone predicted at the previous iteration or time step.

\section{Ground-Water Discharge to Land Surface}

The UZF1 Package also allows for ground-water discharge to the land surface whenever the water table in a cell is higher than the land-surface elevation. The volumetric rate of ground-water discharge to land surface is calculated on the basis of the following equation:

$$
\left.Q_{g w}=A_{\text {cell }} K_{v}(h-\text { celtop }) / 0.5 \text { celth } k\right),
$$

where

$h$ is the water-table elevation; celtop is the land-surface elevation;

$A_{c e l l}$ is the plan-view area of the model cell (equal to the column length times the row length of the model grid);

$K_{v}$ is the vertical hydraulic conductivity of the model cell; and

celthk is the thickness of the model cell.

The value that is subtracted from the HCOF array in MODFLOW-2005 (corresponds to the A matrix in equation 20) is equal to $A_{\text {cell }} K_{v} /(0.5$ celthk $)$. The value subtracted from the RHS array in MODFLOW-2005 (corresponds to the $B$ matrix in equation 20) is equal to $A_{\text {cell }} K_{v}$ celtop $/(0.5$ celthk $)$.

The UZF1 Package includes an option to specify a twodimensional array of values (UZF1 variable IRUNBND) that identify where ground-water discharge to land surface will be added to a stream or lake if the SFR2 and LAK Packages are active. Additionally, the UZF1 Package variable IRUNDF LG must be greater than 1 for water to be added to streams or lakes. Ground-water discharge to land surface and infiltration in excess of the saturated vertical hydraulic conductivity are added instantaneously to specified streams and lakes. The SFR2 Package is documented by Niswonger and Prudic (2006) and the LAK3 Package is documented by Merritt and Konikow (2000).

A water budget for the unsaturated zone is tracked independently of the ground-water budget within MODFLOW-2005. The mass balance for the unsaturated zone accounts for all water between the land surface and the water table. The mass balance for the saturated zone is accounted for in the ground-water budget. When the water table rises above the top of a model cell, then the unsaturated-zone mass balance ceases to be calculated for that cell, and unsaturated storage and the change in unsaturated-zone storage for that cell are set to zero.

There are no procedural limitations regarding stress period and time step lengths associated with the UZF1 Package. However, because the UZF1 Package delays recharge to the water table, changes in stress do not necessarily correspond to the beginning of a stress period. Consequently, caution should be used when simulating time steps that increase during a stress period (specifying the variable TSMULT $>1.0$ in the data input for the Discretization file; Harbaugh, 2005) because water percolating through the unsaturated zone may reach the water table at the end of a stress period, when the time step length is a maximum. 


\section{Steady-State Simulations}

Steady state can be specified for the initial stress period of a simulation when using the UZF1 Package. When steady state is specified for the initial stress period, the ground-water recharge rate computed in UZF1 is set equal to the infiltration rate and ET is not removed from the unsaturated zone. The water content is constant within each model cell during steady state. The specified ET rate is subtracted from the infiltration rate to calculate a steady-state recharge rate. ET can also occur from ground water when the water table is above the ET extinction depth. A uniform water content profile is computed for each active cell, which is used automatically as the initial conditions for a following transient stress period.

Steady-state water content profiles may be printed to a file for specified locations. Initial water content values are not required when the initial stress period is specified as steady state. Thus, initial water-content values must not be specified within the UZF1 input file when the first stress period is steady state. Another option for developing initial water content profiles is to run the model for several years while repeating a cycle of infiltration rates. This step may be carried out subsequent to a steady-state simulation.

\section{Assumptions and Limitations}

The kinematic-wave approximation does not account for capillary-induced infiltration at the onset of wetting when negative pressure gradients are large relative to gravity potential gradients. However, infiltration approaches the unsaturated hydraulic conductivity when the wetting front has advanced sufficiently far beneath the surface (Mein and Larson, 1973; Childs and Bybordi, 1969). Negative pressure gradients also may result in lateral and vertical redistribution in the unsaturated zone. Because negative pressure gradients are ignored, UZF1 likely under predicts the advancement of the wetting front at early times.

Because capillary-induced infiltration is neglected, there is no consideration for the period prior to ponding when the infiltration should be represented by a constant flux equal to the rainfall rate (Smith and Parlange, 1978), rather than the constant water content assigned at the boundary (equation 19). Thus for greater rainfall or snowmelt rates, the model will underestimate infiltration during the onset of infiltration. UZF1 does not simulate a capillary fringe above the water table and it assumes that ground water is instantaneously released from or taken into storage.

The initial version of this package (UZF1) does not simulate unsaturated flow through multiple layers of varying hydraulic properties. The model can simulate unsaturated flow through inactive cells to deeper active model cells. However, the hydraulic properties of an unsaturated column between the land surface and the uppermost active cell are uniform during the simulation and are always equal to their values at the onset of the simulation.

\section{Comparison of UZF1 and VS2DT Simulations}

The kinematic-wave approximation used in the UZF1 Package was compared to the USGS's Variably-Saturated Two-Dimensional Flow and Transport (VS2DT) Model (Healy, 1990). VS2DT solves Richards' equation numerically in terms of pressure head. The results were limited to the simulation of vertical flow through a column.

\section{Description}

Percolation through the unsaturated zone was simulated with VS2DT as a 30-m long vertical column of materials having hydraulic properties typical of a sandy clay loam, whereas percolation through the unsaturated zone was simulated with the UZF1 Package and MODFLOW-2005 for a single cell (row 10, column 4) from the model in test simulation 2, described herein. The initial water table in row 10 , column 4 was $22 \mathrm{~m}$ below land surface and the water table declined less than $1 \mathrm{~m}$ during the simulation period. The same variables that describe the unsaturated zone were used in both model simulations (table 1). The wetting front did not reach the water table for both simulations because the comparison was done to test differences in the propagation of the wetting front with varying ET demand rates. VS2DT simulates evaporation separate from transpiration by root uptake; only transpiration was used in the simulation. Total simulation time was 17.7 days. A variable time step was used in the simulation with VS2DT, whereas a constant time step was used in the UZF1/MODFLOW-2005 simulation.

Table 1. Unsaturated zone variables used in comparison of results from the Unsaturated-Zone Flow (UZF1) Package in MODFLOW-2005 with those from the Variably-Saturated Two-Dimensional Flow and Transport (VS2DT) Model.

[Abbreviations: $\mathrm{m}$, meter; $\mathrm{m} / \mathrm{s}$, meter per second; $\mathrm{m}^{3}$, cubic meter]

\begin{tabular}{lc}
\hline \multicolumn{1}{c}{ Variable } & Value \\
\hline Saturated vertical hydraulic conductivity $(\mathrm{m} / \mathrm{s})$ & $4 \times 10^{-6}$ \\
Saturated water content $\left(\mathrm{m}^{3}\right.$ of water per $\mathrm{m}^{3}$ of aquifer $)$ & 0.4 \\
Residual water content $\left(\mathrm{m}^{3}\right.$ of water per $\mathrm{m}^{3}$ of aquifer) & 0.2 \\
Brooks-Corey exponent (dimensionless) & 3.5 \\
Air entry pressure $(\mathrm{m})^{1}$ & -0.05 \\
Infiltration rate $(\mathrm{m} / \mathrm{s})$ & $2 \times 10^{-6}$ \\
Evapotranspiration extinction depth $(\mathrm{m})$ & 2 \\
Evapotranspiration rate $(\mathrm{m} / \mathrm{s})$ & \\
$\quad$ Simulation 1 & $5 \times 10^{-8}$ \\
$\quad$ Simulation 2 & $5 \times 10^{-7}$ \\
$\quad$ Simulation 3 & $1 \times 10^{-6}$ \\
\hline
\end{tabular}

${ }^{1}$ Value was not used in the simulation with the Unsaturated-Zone Flow (UZF1) Package in MODFLOW-2005. 
A constant infiltration rate was applied at the upper boundary of the column and was $2.0 \times 10^{-6} \mathrm{~m} / \mathrm{s}$. The infiltration rate was half the saturated vertical hydraulic conductivity (table 1). The constant infiltration rate at land surface was converted to water content within UZF1 on the basis of equation 19. The initial water content was set equal to the residual water content throughout the unsaturated zone. The ET extinction depth was set at a depth of $2 \mathrm{~m}$ below land surface, and an ET demand rate of $5.0 \times 10^{-8} \mathrm{~m} / \mathrm{s}, 5.0 \times 10^{-7}$ $\mathrm{m} / \mathrm{s}$, and $1.0 \times 10^{-6} \mathrm{~m} / \mathrm{s}$ was specified for simulations 1,2 and 3 , respectively (table 1). Although the two highest ET demand rates used in this example are too high to represent any actual conditions, they serve to demonstrate the model's accuracy during extreme situations.

\section{Results}

Advancement and magnitude of the wetting front for all three simulations of differing specified ET rates were nearly the same for both models (fig. 4). The kinematicwave approximation in UZF1 slightly under-predicted the advancement of the wetting front at early time and overpredicted advancement at later time. The effect was more pronounced when the ET demand rate was $1.0 \times 10^{-6} \mathrm{~m} / \mathrm{s}$ fig. $4 C$ ). Discrepancies between UZF1 and VS2DT for each simulation were related to neglecting the negative pressure gradients with the kinematic-wave approximation.

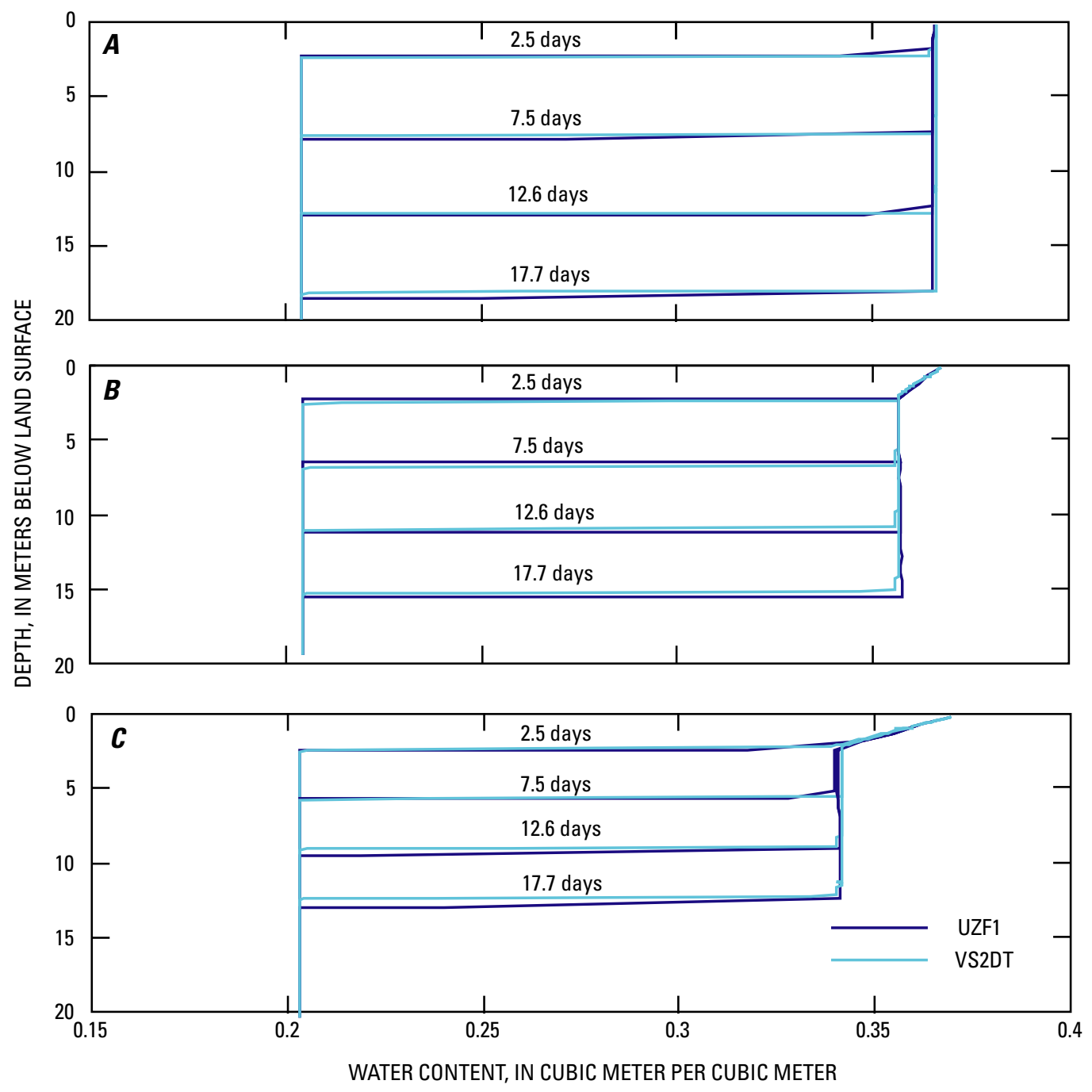

Figure 4. Comparison of results from the kinematic-wave approximation used to simulate unsaturated flow (UZF1) with a two-dimensional finite-difference solution of Richards' equation (VS2DT; Healy, 1990) assuming evapotranspiration demand rates of: $(A) 5 \times 10^{-8}$ meter per second, $(B) 5 \times 10^{-7}$ meter per second, and $(C) 1 \times 10^{-6}$ meter per second. 


\section{Test Simulations}

Two hypothetical test simulations are used to illustrate the capabilities of the UZF1 Package. The first is an application of the model to a watershed that encompasses an area of $27 \mathrm{~km}^{2}$. This simulation was designed to demonstrate all the capabilities of UZF1. However, because the first test simulation involved relatively large data input and model output files that are not easily printed, a second simpler test simulation is described that can be used as a guide for data input and model output structure and to verify proper installation of the UZF1 Package in MODFLOW-2005. Detailed results are described for the first test simulation in this document, but the data input and model output are not included as part of the printed document. However, data input and model output for the second test simulation are included in appendix 2 along with a summary of the unsaturated-zone and ground-water budgets in the discussion of the second test simulation. Both test simulations and this report are available at http://water.usgs.gov/software/.

\section{Test Simulation 1: Sagehen Watershed}

The first test simulation is a conceptual yet realistic simulation of the Sagehen watershed (fig. 5), a USGS Hydrologic Benchmark Network Basin located on the eastern slope of the northern Sierra Nevada, near Truckee, California (Mast and Clow, 2000). The basin drains an area of $27 \mathrm{~km}^{2}$ and ranges in altitude from 1,926 to 2,663 m above mean sea level. The areally averaged annual precipitation is about $970 \mathrm{~mm}$ and the annual hydrograph is dominated by snowmelt. The Sagehen watershed comprises volcanic rocks overlain by a veneer of alluvium.

The test simulation consisted of a single model layer with 73 rows and 81 columns in which all cells had a constant width and length equal to $90 \mathrm{~m}$ (fig. 5). The top elevations of model cells were set equal to estimated land-surface altitudes for each cell; the elevation of the bottom of the aquifer (bottom of model cells) ranged from 1,830 to 2,480 m above mean sea level. The simulation period was 1-year beginning on December 1 and ending November 30. The simulation period was divided into 365 1-day stress periods. The first stress period was steady state, and subsequent stress periods were transient. One time step was simulated for each stress period. No-flow conditions were simulated across the bottom and sides of the model except for three cells beneath and adjacent to the stream at the basin outlet, which were specified as constant head cells.
Several packages and optional files were used in the simulation of the Sagehen watershed (table 2). The LayerProperty Flow (LPF) Package (Harbaugh and others, 2000, p. 59) was used and both horizontal and vertical hydraulic conductivity values were specified. Because one layer was specified in the model, the vertical hydraulic conductivity of the aquifer only affected ground-water seepage to land surface. All cells were specified as convertible (unconfined). The horizontal hydraulic conductivity ranged from $0.005 \mathrm{~m} / \mathrm{d}$ on the ridges to $0.3 \mathrm{~m} / \mathrm{d}$ in the valleys (table 3 ). A lower hydraulic conductivity was specified on the ridges where volcanic rocks are near the surface (fig. 5). The hydraulic conductivity within each cell was assumed isotropic. Specific storage was set to $5 \times 10^{-7} \mathrm{~m}^{-1}$, and the specific yield was specified as 0.05 on the ridges and 0.25 in the valleys near streams.

The vertical hydraulic conductivity of the unsaturated zone had the same values as the horizontal and vertical hydraulic conductivity used in the LPF Package (table 3). A constant Brooks-Corey exponent of 4 and a constant saturated water content of 0.3 were assigned to all cells.

The streams were represented by 15 segments made up of 201 reaches using the Streamflow-Routing (SFR2) Package (Niswonger and Prudic, 2006) and included the simulation of unsaturated flow beneath streams. All stream reaches were set to a constant width of $3 \mathrm{~m}($ ICALC $=1)$ and ranged in length from 30 to $114 \mathrm{~m}$. The streambed and unsaturated zone hydraulic conductivity were equal to $0.3 \mathrm{~m} / \mathrm{d}$ (table 3 ). Unsaturated-zone properties were constant among all stream reaches. Saturated water content beneath the stream was 0.30 . The Brooks-Corey exponent was 3.5.

The distribution of hydraulic conductivity was created initially on the basis of the surface geology. The distribution of hydraulic conductivity was adjusted during a steady-state calibration that assumed that the spatially varying groundwater recharge was proportional to the distribution of mean annual precipitation. Precipitation was distributed according to $860 \mathrm{~mm}$ below an altitude of 2,100 $\mathrm{m}$ and increased linearly above $2,100 \mathrm{~m}$ to a maximum of $1,140 \mathrm{~mm}$ at an altitude of $2,600 \mathrm{~m}$. The range in ground-water recharge for the steadystate simulation was determined by approximating the mean daily discharge at the outlet of the Sagehen watershed in early December. The steady-state simulation resulted in a calculated water table that was as much as $80 \mathrm{~m}$ below land surface along the ridges and at, or slightly above, land surface in the lowest parts of the valleys next to streams (fig. 6). Although no observation wells have been drilled on the ridges in the watershed, the maximum depth to ground water was based on depths measured in wells elsewhere in the northern Sierra Nevada. 


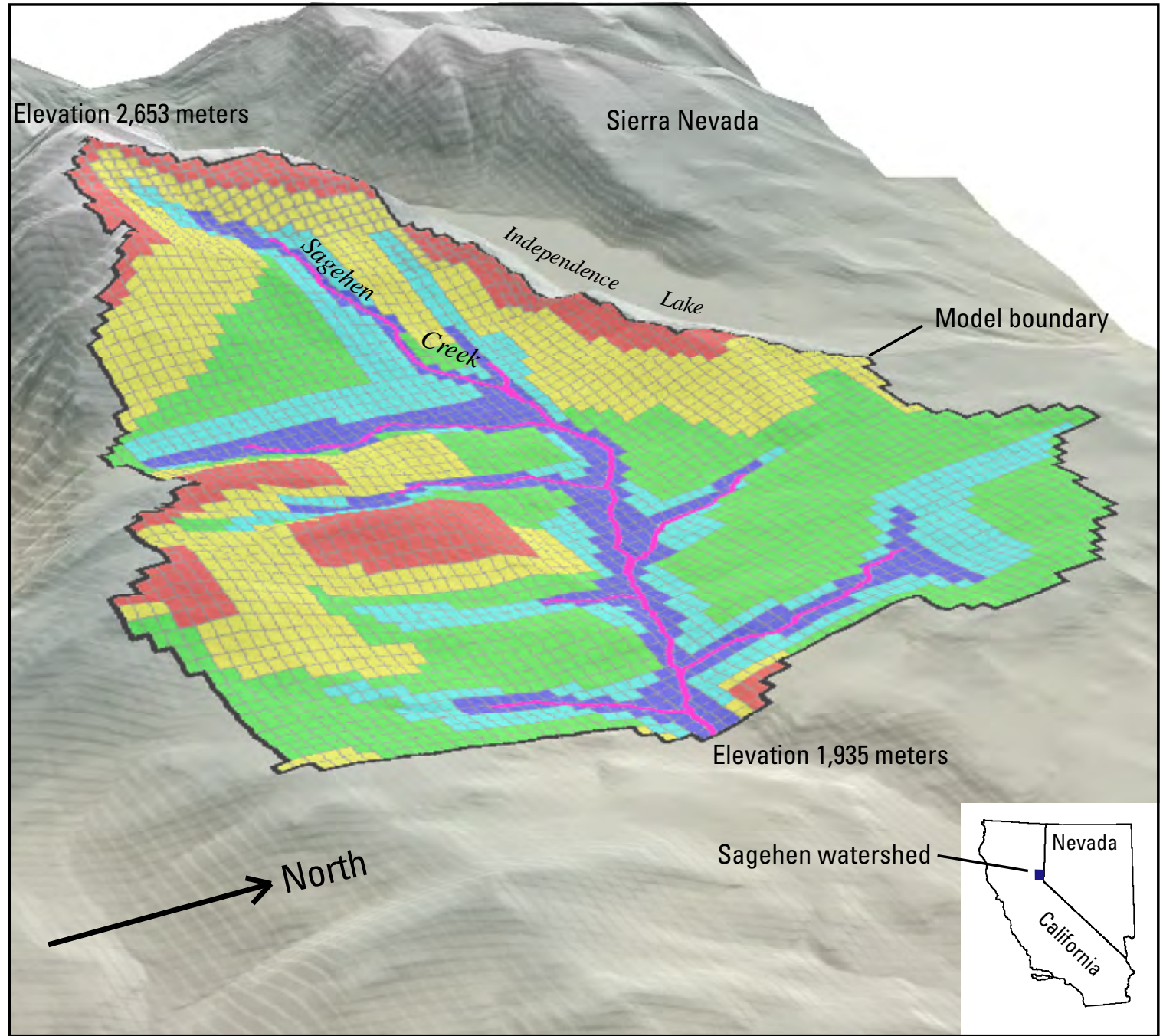

Shaded relief base from USGS 10-meter National Elevation Data, illumination from the northwest at $45^{\circ}$.

Albers Equal-Area Conic projection

Perspective Information:

Altitude is 7,300 meters above land surface

Viewing angle is 25 degrees

Standard parallels $29^{\circ} 30^{\prime} \mathrm{N}$ and $45^{\circ} 30^{\prime} \mathrm{N}$, central meridian $120^{\circ} 00^{\prime} \mathrm{W}$

Vertical exaggeration times 2

North American Datum of 1983

\section{EXPLANATION}

Hydraulic Conductivitymeter per day

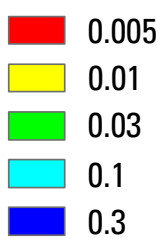

Figure 5. Distribution of hydraulic conductivity from ground-water model used for test simulation 1 . 
Table 2. MODFLOW-2005 Packages and files used for test simulation 1.

\section{MODFLOW-2005 Packages and Files}

Basic (BAS6) Package

Output Control (OC) Option file

Discretization (DIS) file

Layer-Property Flow (LPF) Package

Preconditioned Conjugate-Gradient (PCG) Solver Package

Unsaturated-Zone Flow (UZF1) Package

Streamflow-Routing (SFR2) Package

Gage (GAG) Package
The initial water content of the unsaturated zone was calculated on the basis of the simulated steady-state recharge rate, which equaled the infiltration rate at land surface. An ET extinction depth of $2.5 \mathrm{~m}$ was assigned to all cells (table 3 ) and ET from the upper $2.5 \mathrm{~m}$ was simulated on the basis of the assigned ET demand rate. Water was first removed from the unsaturated zone and then from the saturated zone only when the water table was within $2.5 \mathrm{~m}$ of land surface. The water content for ET extinction was set to a constant of 0.1002. Infiltration and ET demand rates were specified for each stress period and were estimated assuming infiltration and ET were at a minimum from December 1 to mid-April,

Table 3. Hydraulic properties and other selected variables used in the Layer-Property Flow (LPF) and the Unsaturated-Zone Flow (UZF1) Packages for test simulation 1.

[Abbreviations: $\mathrm{m}$, meter; $\mathrm{m} / \mathrm{d}$, meter per day; $\mathrm{m}^{3}$, cubic meter]

\begin{tabular}{|c|c|}
\hline Variable & Value \\
\hline Vertical hydraulic conductivity of aquifer $(\mathrm{m} / \mathrm{d})$ & 0.005 to 0.3 \\
\hline Specific storage (per $\mathrm{m}$ of aquifer) & $5 \times 10^{-7}$ \\
\hline Specific yield ( $\mathrm{m}^{3}$ of water per $\mathrm{m}^{3}$ of aquifer) & 0.05 to 0.25 \\
\hline Vertical hydraulic conductivity of the unsaturated zone beneath land surface (m/d) & 0.005 to 0.3 \\
\hline Brooks-Corey exponent for unsaturated zone beneath land surface (unitless) & 4.0 \\
\hline Saturated water content of unsaturated zone beneath land surface $\left(\mathrm{m}^{3}\right.$ of water per $\mathrm{m}^{3}$ of unsaturated zone) & 0.3 \\
\hline Initial water content of unsaturated zone beneath land surface $\left(\mathrm{m}^{3}\right.$ of water per $\mathrm{m}^{3}$ of unsaturated zone) & 0.2 \\
\hline Steady-state infiltration rate $(\mathrm{m} / \mathrm{d})$ & 0.0004 to 0.00104 \\
\hline \multicolumn{2}{|l|}{ Variables assigned to the Streamflow-Routing (SFR2) Package } \\
\hline Hydraulic conductivity of streambed (m/d) & 0.3 \\
\hline Streambed thickness (m) & 1.0 \\
\hline Vertical hydraulic conductivity of unsaturated zone beneath streams (m/d) & 0.3 \\
\hline Brooks-Corey exponent for unsaturated zone beneath streams (unitless) & 3.5 \\
\hline Saturated water content of unsaturated zone beneath streams ( $\mathrm{m}^{3}$ of water per $\mathrm{m}^{3}$ of unsaturated zone) & 0.3 \\
\hline
\end{tabular}




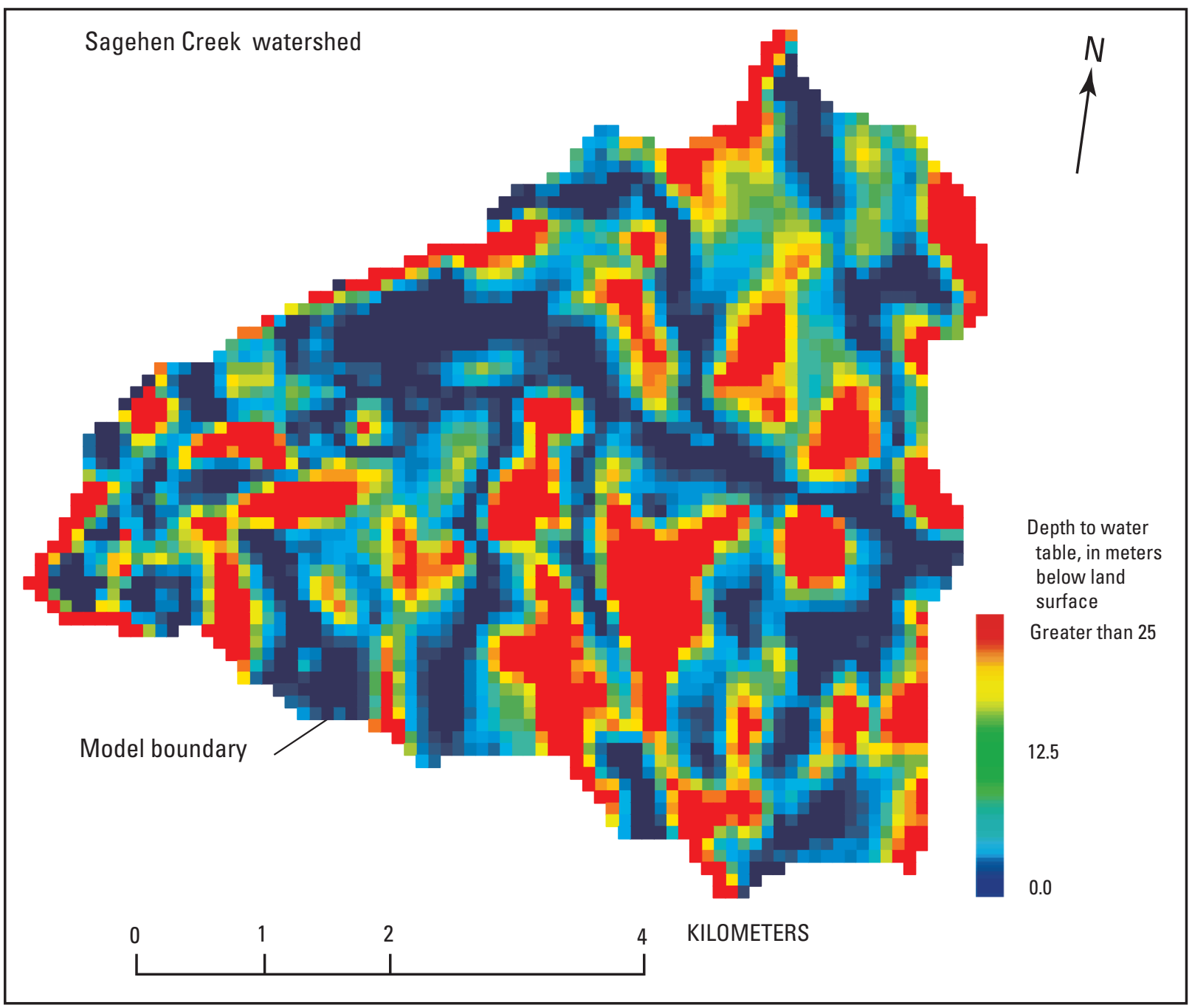

Figure 6. Distribution of steady-state ground-water depths used for test simulation 1.

infiltration increased to a maximum during May, and the daily ET demand increased to a maximum during June (fig. 7). The specified infiltration rates varied in the model and were three times greater at the tops of the ridges as compared to the valley lowlands (fig. 8). The range in the applied infiltration rates were estimated on the basis of the average difference between the two precipitation gages located in the upper and lower portions of the watershed.
The Preconditioned Conjugate-Gradient (PCG) Package was used to solve for ground-water head throughout the model domain. The head-closure criterion used in the transient simulation was $0.0009 \mathrm{~m}$ and the flow-closure criterion was $0.005 \mathrm{~m}^{3} / \mathrm{d}$. The absolute mass-balance error for the unsaturated zone ranged from 0 to 0.08 percent for all stress periods and the saturated zone ranged from 0 to 0.22 percent. The cumulative mass-balance error at the end of the 365day simulation was 0 percent for the unsaturated zone and 0.10 percent for the saturated zone. 


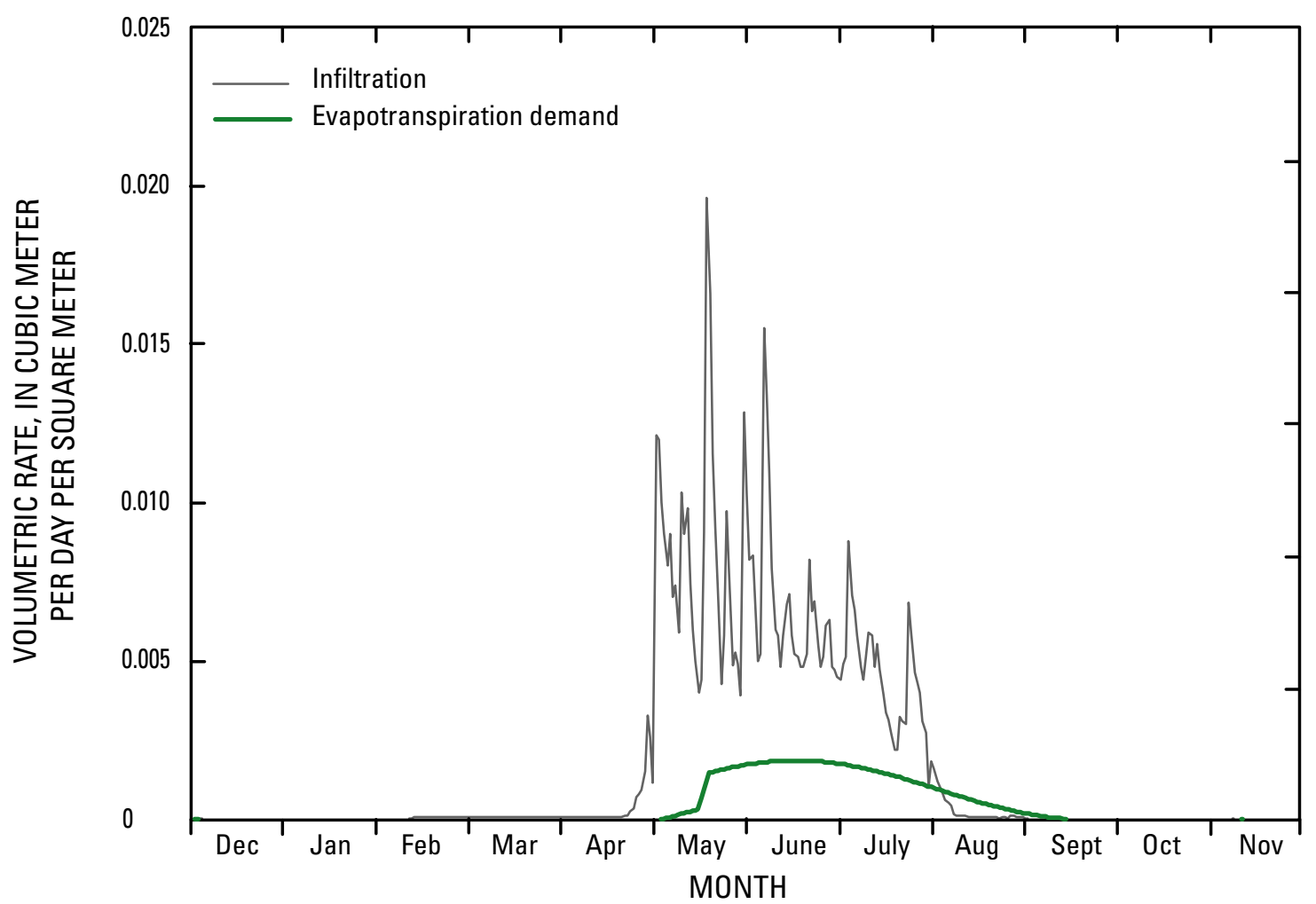

Figure 7. Infiltration rate and evapotranspiration demand used for test simulation 1. The infiltration rate was multiplied by the spatial distribution of infiltration factors shown in figure 8 . ET demand was constant over the model and was satisfied by storage in the unsaturated zone or from ground water.

Results from the transient simulation of ET and percolation through the unsaturated zone indicate that recharge patterns are a result of the cumulative effects of ET, spatially varying recharge, hydraulic conductivity, topography, and thickness of the unsaturated zone. Model calculated groundwater recharge summed over the entire basin indicates two distinct patterns: a nearly immediate response to peaks in infiltration in the valley lowlands where the unsaturated zone is thin, and a diffuse response that varies slowly over several months in upland areas where the unsaturated zone is relatively thick (fig. 9).

The simulated volumetric ET rate was correlated to the specified ET demand rate. The cumulative volumetric ET rate for the watershed was limited by water availability in the unsaturated zone and the depth to the water table, except during periods of high infiltration. Because the water table generally was deeper than the ET extinction depth for most of the watershed, a larger proportion of ET was removed from the unsaturated zone (fig. 9). However, the quantity of ET loss is sensitive to the extinction depth and extinction water content, such that attention should be placed on estimating the extinction depth and extinction water content to reduce uncertainty in recharge estimates.
Most of the simulated streamflow during the first six months was from ground-water discharge to the stream (fig. 10). Total overland flow, including ground-water discharge to land surface plus saturation excess, exceeded ground-water discharge to streams beginning mid-May until mid-August. After mid-August, total overland flow was diminished and ground-water discharge to streams dominated the hydrograph (fig. 10).

The outlet streamflow at the end of the simulation period was greater by $5,900 \mathrm{~m}^{3} / \mathrm{d}$ than that at the beginning; whereas overland flow caused by ground-water discharge to land surface (spring flow) was greater by $1,700 \mathrm{~m}^{3} / \mathrm{d}$ (fig. 10). The greater ground-water discharge at the end of the simulation is consistent with the greater mean recharge of $46,700 \mathrm{~m}^{3} / \mathrm{d}$ for the one-year simulation compared with a mean recharge of $10,400 \mathrm{~m}^{3} / \mathrm{d}$ for the steady-state period. The results of the simulation show how a year of well-above-mean recharge may have a prolonged effect on ground-water discharge to land surface and to streams. 


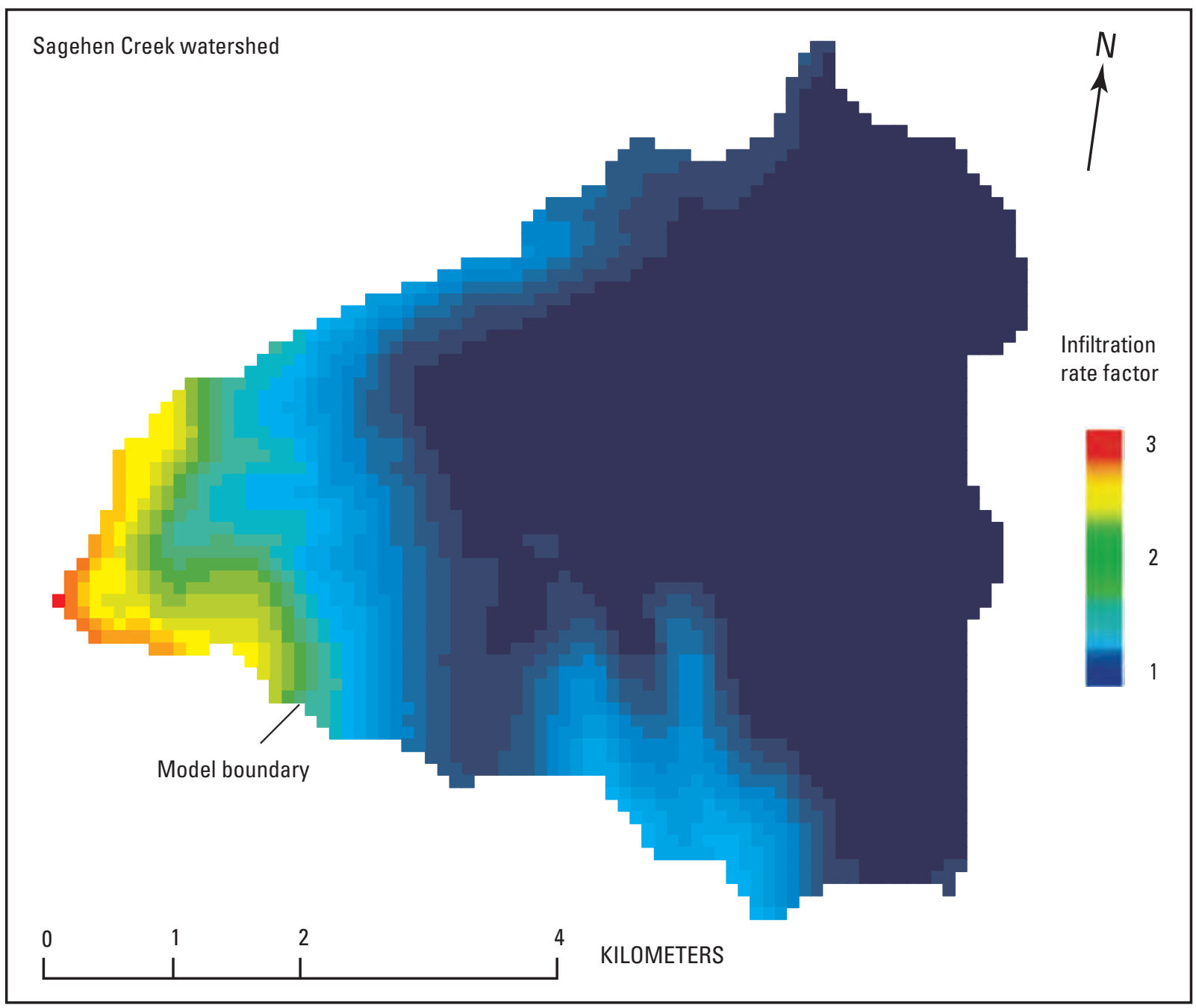

Figure 8. Distribution of infiltration factors used for test simulation 1.

The factors were multiplied by infiltration rates that varied daily as shown in figure 7. Infiltration factors are based on land-surface altitude and were used to account for variations of precipitation in relation to altitude.

Infiltration and ground-water recharge during the simulations resulted in a general increase of ground-water seepage to land surface between the beginning of the simulation and the end of June when ground-water recharge was at its peak (fig. 10). The increase in the area over which ground water discharged to land surface caused the increase in overland runoff (ground-water discharge to land surface plus saturation excess) shown in figure 11.

Water-content profiles beneath individual models cells indicate that the water content follows a seasonal envelope that becomes narrower with depth because of the seasonal pattern of infiltration and ET (fig. 12). The water-content profiles illustrate the utility of the kinematic-wave approximation in computing vertical flow through the unsaturated zone. The wetting front created by many different infiltration rates took longer than a year to reach the water table in areas where the saturated vertical hydraulic conductivity was low and depth to ground water was greater than $20 \mathrm{~m}$ below land surface.

The marked difference among infiltration, recharge, and streamflow for the example of the Sagehen watershed suggests that the unsaturated zone could have a strong effect on fluctuations in ground-water levels and streamflow during and after storms. Years in which infiltration rates exceed the mean annual rate may increase ground-water storage even in relatively poorly permeable rocks and result in increased discharge to streams that may extend well beyond the period of infiltration. The UZF1 Package in MODFLOW-2005 provides a method in which daily-averaged values of overland runoff and saturation excess runoff can be simulated in a complex, yet simplified, manner. 


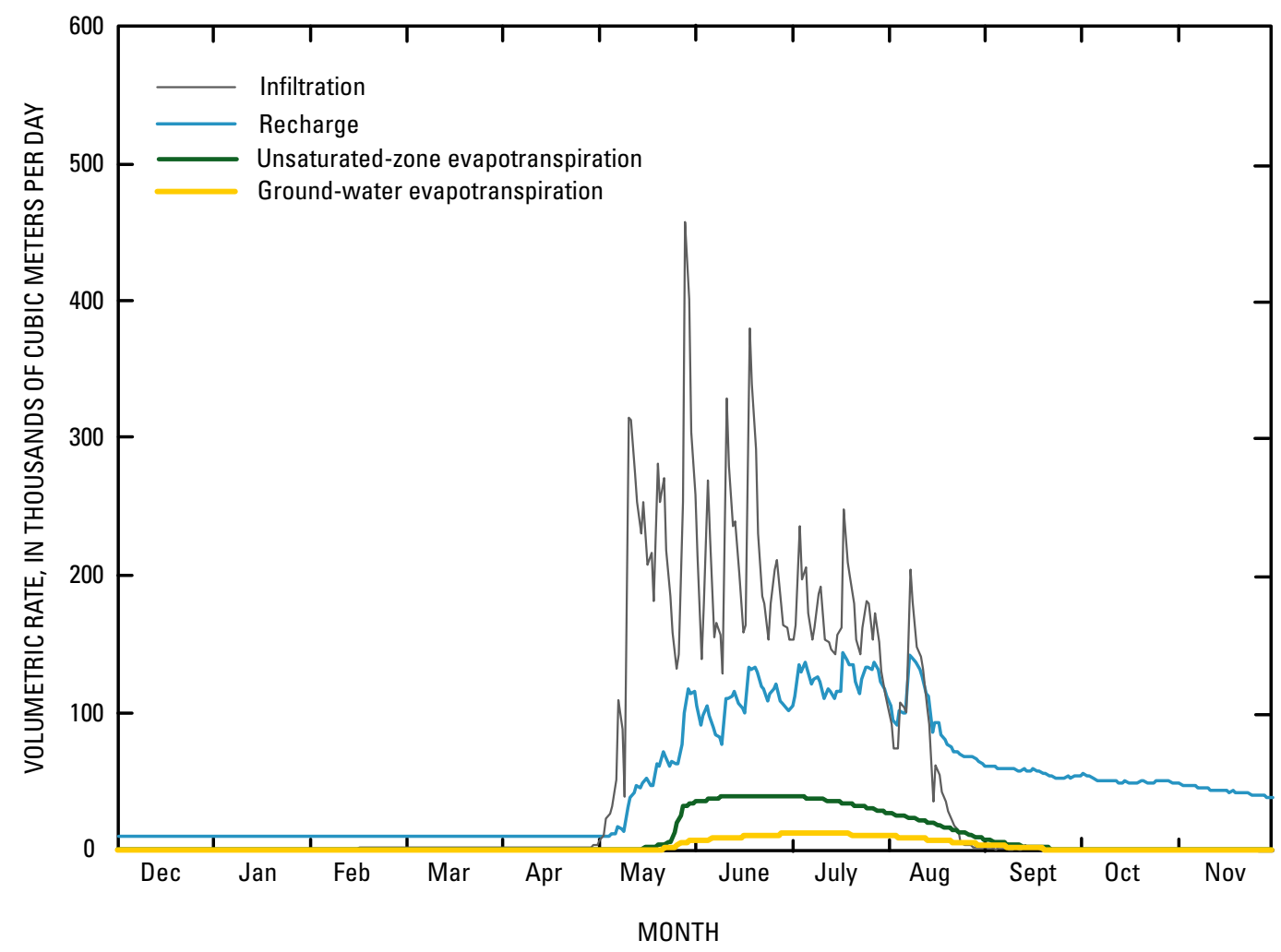

Figure 9. Volumetric rates of infiltration, recharge, and evapotranspiration summed over the model domain for test simulation 1.

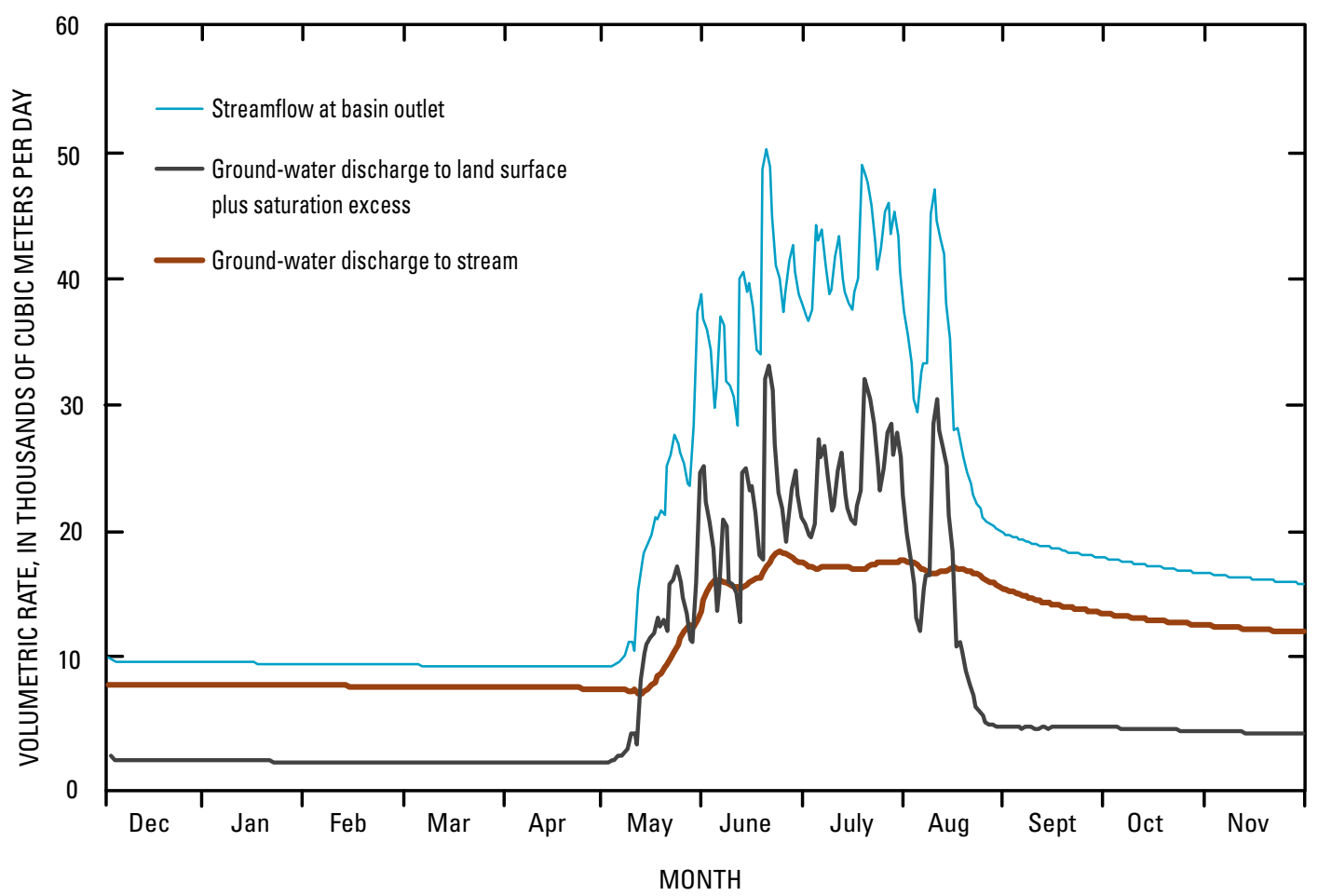

Figure 10. Streamflow at the basin outlet, ground-water discharge to land surface plus saturation excess, and ground-water discharge to streams for test simulation 1. 


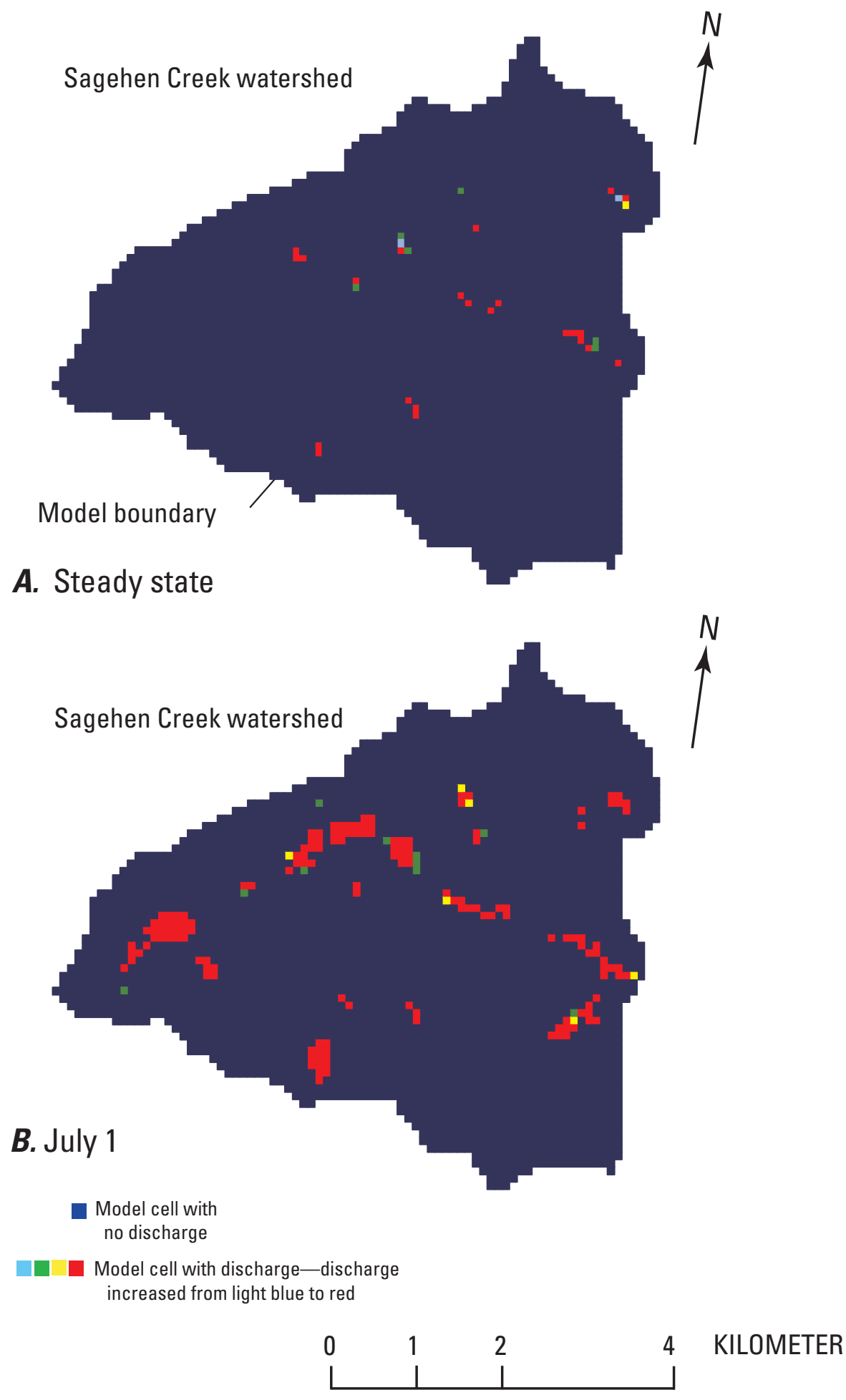

Figure 11. Distribution of ground-water seepage to land surface for $(A)$ steady state, and $(B)$ July 1 . 


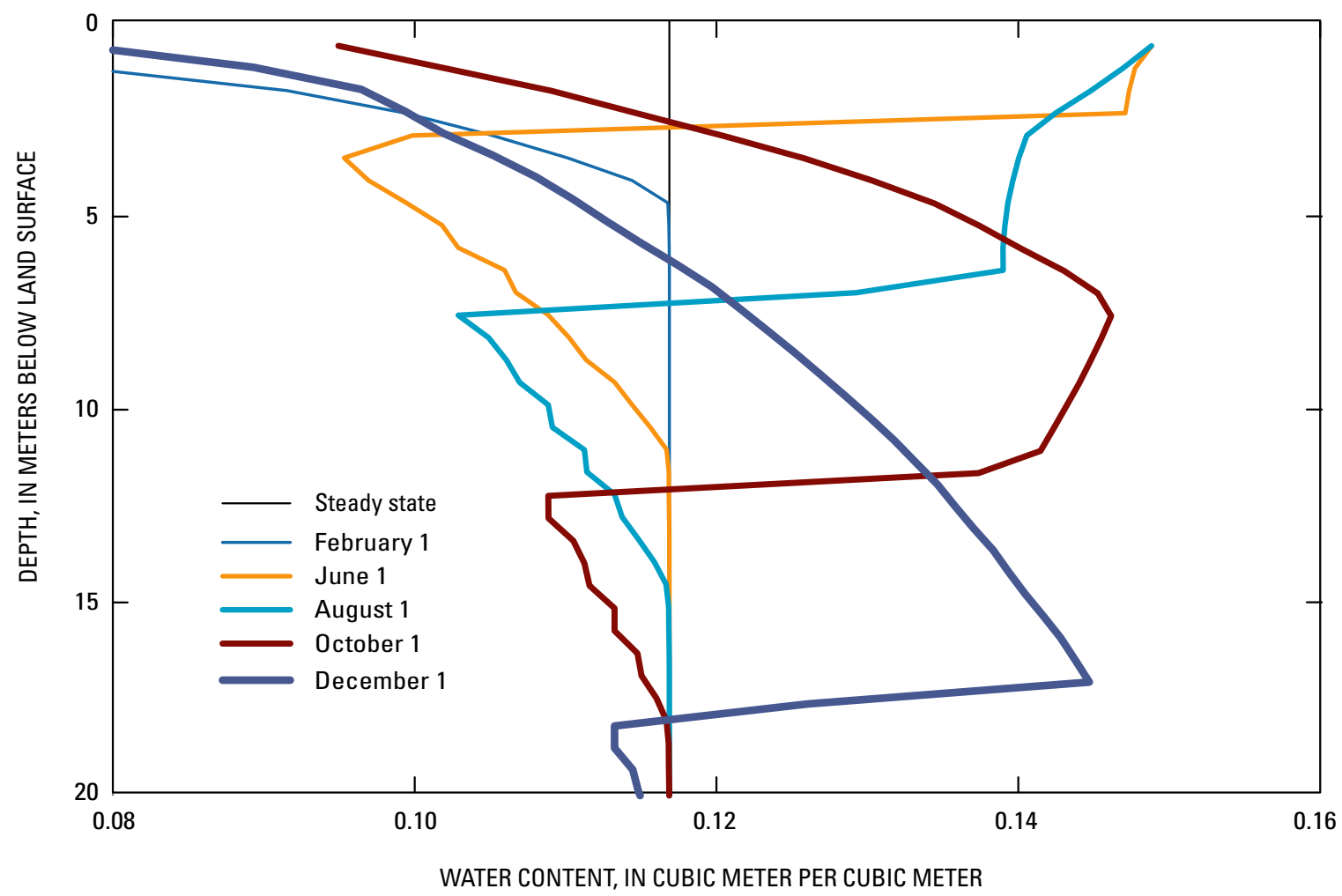

Figure 12. Water-content profiles in the unsaturated zone of a model cell located in an upland area (column 9, row 36) at selected dates for test simulation 1 .

\section{Test Simulation 2: Simple Hypothetical Problem}

A second smaller test problem was developed for use as a data-input template and testing proper code installation. Abbreviated listings of the data-input and output files for test simulation 2 are included in appendix 2.

Test simulation 2 used the hypothetical stream-aquifer interaction problem described in Prudic and others (2004; p. 13-19), except the UZF1 Package was used to replace the ET and Recharge Packages. The units used in the hypothetical stream-aquifer interaction problem were in English units, and were not converted to SI units for test simulation 2. Thus, the data input and printed output listed in tables 4-8 and in appendix 2 are in English units.

The hypothetical stream-aquifer interaction problem used in this test simulation was developed for an alluvial basin in a semiarid region. The principal aquifer comprises unconsolidated deposits of mostly sand and gravel. Recharge to the aquifer primarily is leakage from the streams that enter the basin from the mountains on the northwest, northeast, and southwest (fig. 13). The main stream in the southern part of the valley is perennial, whereas all other streams in the valley are intermittent with small drainage areas.

Streamflow entering the model domain and diversions from streams were the same as that used by Prudic and others (2004) and remained the same for all stress periods (table 4). Different methods were used to represent the relations between width, depth and flow in the streams (see ICALC in table 4 and ICALC option descriptions in Prudic and others, 2004). Infiltration rates in the UZF1 Package file and pumping rates in the Well Package file were varied during 12 stress periods (table 5) but the distribution of infiltration and pumping among grid cells did not change. The ET demand was specified as constant over the entire modeled area equal to $1.6 \mathrm{ft} / \mathrm{yr}$ to a maximum depth of $15 \mathrm{ft}$ below land surface. The LPF Package was used to specify hydraulic properties for the aquifer. The hydraulic conductivity and specific yield were $173 \mathrm{ft} / \mathrm{d}$ and 0.2 , respectively, in the vicinity of the stream channels and the hydraulic conductivity and specific yield were $35 \mathrm{ft} / \mathrm{d}$ and 0.1 , respectively, elsewhere in the alluvial basin (fig. 14; table 6). 


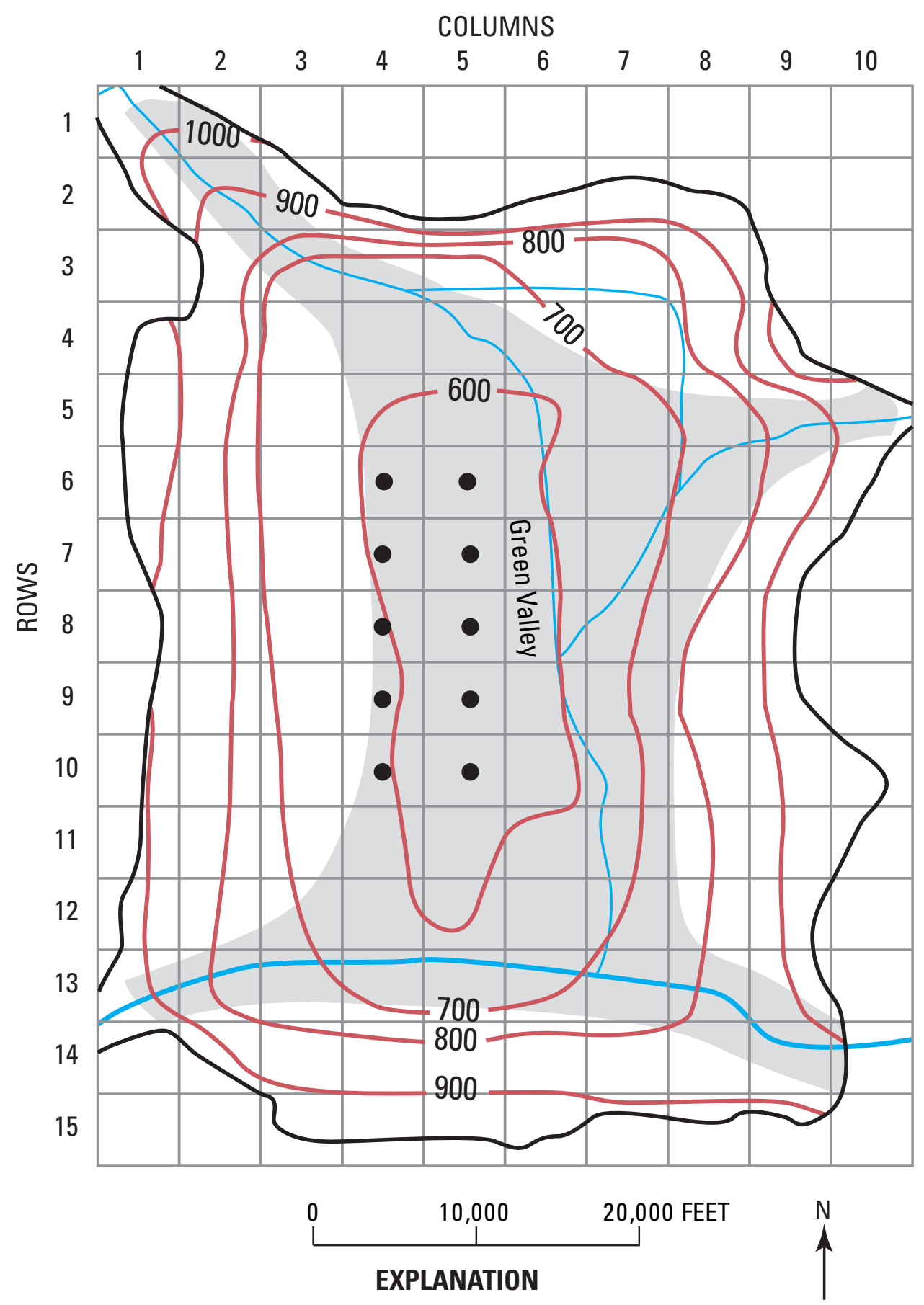

Hydraulic conductivity $=173$ feet per day; specific yield $=0.2$

Hydraulic conductivity $=35$ feet per day; specific yield $=0.1$

-900 - Top of consolidated rock contour-Shows elevation of top of consolidated rock. Contour interval is 100 feet

Basin-fill boundary

Well

Figure 13. Well locations, elevation of top of consolidated rocks beneath basin-fill aquifer, and distribution of hydraulic conductivity and specific yield of the basin-fill aquifer used in test simulation 2. (Modified from Prudic and others, 2004.) 


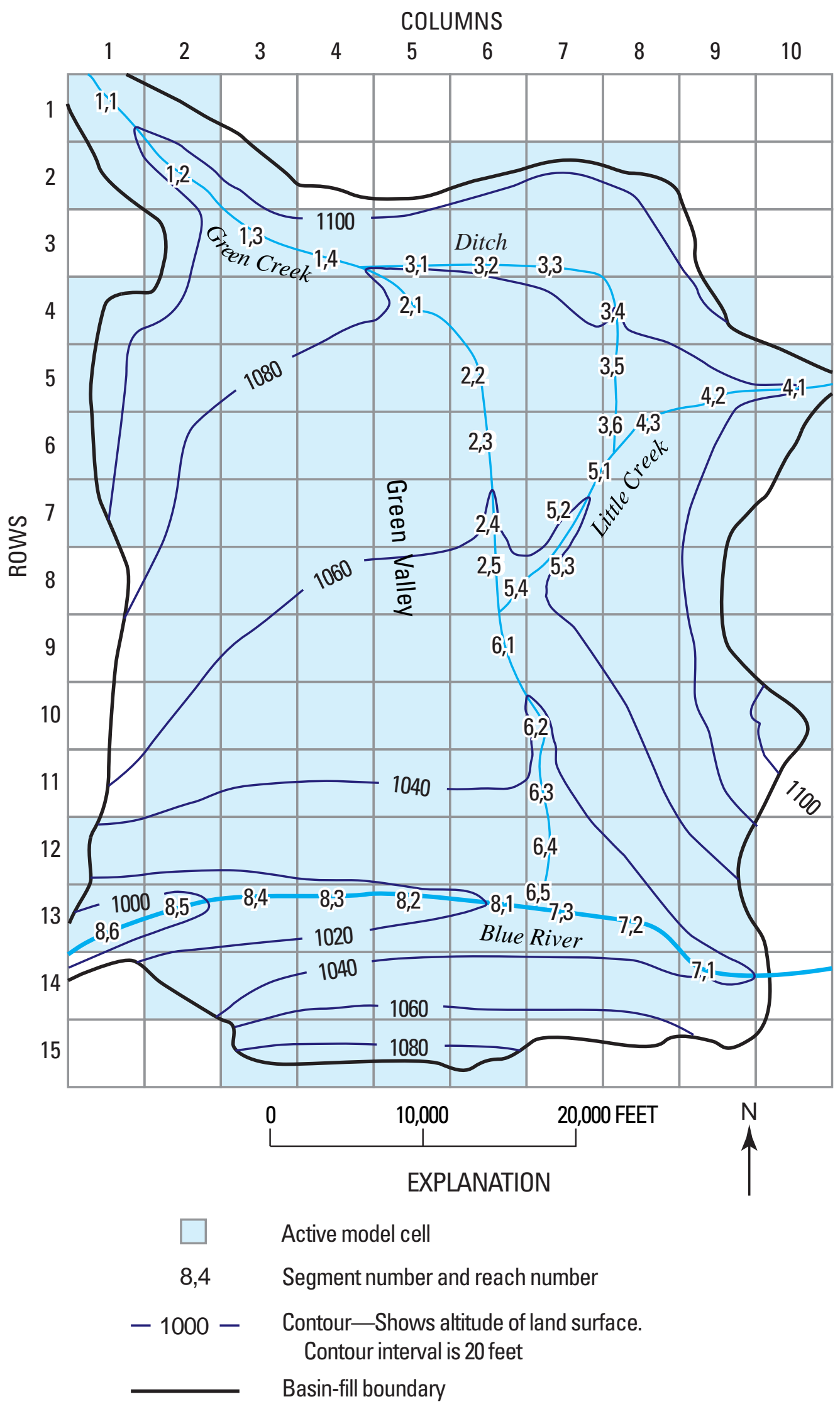

Figure 14. Hypothetical basin-fill aquifer with model grid, land-surface contours, active cells, and stream segment and reach numbering for test simulation 2.

(Modified from Prudic and others, 2004). 
Table 4. Method for calculating stream depth and width, inflow rates, streambed properties, stream dimensions, and Manning's roughness coefficients for stream segments used in test simulation 2.

[Stream: Streambed properties and stream dimensions for each stream segment are specified for the first and last reach in each segment. A linear interpolation is used to determine each value at the midpoint of each reach. Stream segment no: Segment 3 is a diversion from segment 2 assuming all available flow to the rate specified is diverted. Method determines how stream depth and width are calculated for each reach in a segment. Stream depth and width are specified when ICALC is 0; stream depth is calculated from Manning's equation assuming a wide rectangular channel when ICALC is 1; stream depth and width are calculated from Manning's equation using an eight-point cross section when ICALC is 2; depth and width are calculated from a power function when ICALC is 3; and depth and width are calculated from a table of values when ICALC is 4. See appendix 1 in Prudic and others (2004). Inflow rate: Inflow calculated from 1 or more tributary segments. Manning's roughness coefficient is not used for calculating stream depth or width when ICALC is 0,3, or 4, and Manning's roughness coefficient for the overbank is not used when ICALC is 1 . Abbreviations: $\mathrm{ft}$, foot; $\mathrm{ft} / \mathrm{s}$, foot per second; $\mathrm{ft}^{3} / \mathrm{s}$, cubic foot per second]

\begin{tabular}{|c|c|c|c|c|c|c|c|c|c|c|}
\hline \multicolumn{2}{|c|}{ Stream } & \multirow{2}{*}{$\begin{array}{l}\text { Method } \\
\text { (ICALC) }\end{array}$} & \multirow{2}{*}{$\begin{array}{c}\text { Inflow rate } \\
\left(\mathrm{ft}^{3} / \mathrm{s}\right)\end{array}$} & \multirow{2}{*}{$\begin{array}{l}\text { Streambed } \\
\text { hydraulic } \\
\text { conductivity } \\
\text { (ft/s) }\end{array}$} & \multirow{2}{*}{$\begin{array}{c}\text { Streambed } \\
\text { thickness } \\
\text { (ft) }\end{array}$} & \multirow{2}{*}{$\begin{array}{c}\text { Elevation of } \\
\text { streambed } \\
\text { (ft) }\end{array}$} & \multirow{2}{*}{$\begin{array}{l}\text { Stream } \\
\text { depth (ft) }\end{array}$} & \multirow{2}{*}{$\begin{array}{l}\text { Stream } \\
\text { width (ft) }\end{array}$} & \multicolumn{2}{|c|}{$\begin{array}{l}\text { Manning's roughness } \\
\text { coefficient (unitless) }\end{array}$} \\
\hline $\begin{array}{l}\text { Segment } \\
\text { No. }\end{array}$ & $\begin{array}{l}\text { First and } \\
\text { last reach }\end{array}$ & & & & & & & & Channel & Over bank \\
\hline 1 & $\begin{array}{l}1 \\
4\end{array}$ & 4 & 25 & $\begin{array}{r}0.00003 \\
.00003\end{array}$ & $\begin{array}{l}3 \\
3\end{array}$ & $\begin{array}{l}1,095 \\
1,075\end{array}$ & $\begin{array}{l}- \\
-\end{array}$ & $\begin{array}{l}- \\
-\end{array}$ & - & - \\
\hline 3 & $\begin{array}{l}1 \\
6\end{array}$ & 0 & 10 & $\begin{array}{l}.00003 \\
.00003\end{array}$ & $\begin{array}{l}2 \\
2\end{array}$ & $\begin{array}{l}1,075 \\
1,060\end{array}$ & $\begin{array}{l}2 \\
1\end{array}$ & $\begin{array}{r}10 \\
6\end{array}$ & - & - \\
\hline 4 & $\begin{array}{l}1 \\
3\end{array}$ & 1 & 10 & $\begin{array}{l}.00003 \\
.00003\end{array}$ & $\begin{array}{l}3 \\
3\end{array}$ & $\begin{array}{l}1,080 \\
1,060\end{array}$ & - & $\begin{array}{l}10 \\
10\end{array}$ & .030 & - \\
\hline 7 & $\begin{array}{l}1 \\
3\end{array}$ & 2 & 150 & $\begin{array}{l}.00003 \\
.00003\end{array}$ & $\begin{array}{l}3 \\
3\end{array}$ & $\begin{array}{l}1,040 \\
1,025\end{array}$ & - & - & .025 & 0.045 \\
\hline 8 & $\begin{array}{l}1 \\
6\end{array}$ & 2 & - & $\begin{array}{l}.00003 \\
.00003\end{array}$ & $\begin{array}{l}3 \\
3\end{array}$ & $\begin{array}{r}1,025 \\
990\end{array}$ & - & - & .025 & .045 \\
\hline
\end{tabular}

The model grid was divided into uniformly spaced cells $5,000 \mathrm{ft}$ on each side (fig. 14). The strongly implicit procedure (SIP) was used to solve the flow equation for test simulation 2. The head-closure criterion was 0.0002. The option to add overland runoff to stream segments was specified in the UZF1 Package; however, no ground-water seepage to land surface was simulated in the test. The number of stress periods in the Discretization file was 12 . Each stress period was $2.628 \times 10^{6}$ seconds or 30.42 days. The first stress period was steady state and had one time step. This allowed for the calculation of initial water contents for the unsaturated zone on the basis of the steady-state infiltration rate. The remaining 11 stress periods were transient and were divided into 15 time steps that increased sequentially by a factor of 1.1 .
Water budgets at the end of selected stress periods for ground water and the unsaturated zone are summarized in $\underline{\text { tables } 7}$ and $\underline{8}$, respectively. The results indicate that changes in flow and storage in the unsaturated zone affect groundwater recharge and, when combined with stream interaction, ground-water ET, and ground-water pumping, the effect of the unsaturated zone can be important to the overall assessment of ground-water flow. The absolute mass-balance errors were less than 0.05 percent for both the unsaturatedzone and ground-water budgets, and the cumulative massbalance error was 0 percent for the unsaturated-zone budget and -0.01 percent for the ground-water budget. 
Table 5. Specified infiltration and pumping rates for the 12 stress periods used in test simulation 2.

[English units used for test simulation 2 are consistent with units of example problem as described by Prudic and others (2004) and were not changed to conform to the Standard International units used elsewhere in this document. Infiltration rate was multiplied by the area of each cell $\left(2.5 \times 10^{8}\right.$ square feet $)$ and by a factor that ranged from 1 to 8 . Pumping rate was assigned to 10 model cells (appendix 2). Abbreviations: $\mathrm{ft} / \mathrm{s}$, foot per second; $\mathrm{ft}^{3} / \mathrm{s}$, cubic foot per second]

\begin{tabular}{ccc}
\hline Stress period & $\begin{array}{c}\text { Infiltration rate } \\
(\mathbf{f t} / \mathbf{s})\end{array}$ & $\begin{array}{c}\text { Pumping rate } \\
\left(\mathbf{f t}^{\mathbf{3}} \mathbf{/ s}\right)\end{array}$ \\
\hline 1 & $1 \times 10^{-9}$ & -2 \\
2 & $8 \times 10^{-9}$ & -2 \\
3 & $1 \times 10^{-8}$ & -1 \\
4 & $2 \times 10^{-8}$ & -1 \\
5 & $5 \times 10^{-9}$ & -3 \\
6 & $1 \times 10^{-8}$ & 0 \\
7 & $3 \times 10^{-9}$ & -2 \\
8 & $5 \times 10^{-9}$ & 0 \\
9 & $3 \times 10^{-9}$ & -1 \\
10 & $2 \times 10^{-9}$ & 0 \\
11 & $1 \times 10^{-9}$ & -3 \\
12 & $1 \times 10^{-9}$ & 0 \\
\hline
\end{tabular}

Table 6. Hydraulic properties and other selected variables used in the Layer-Property Flow (LPF) and Unsaturated-Zone Flow (UZF1) Packages for test simulation 2.

[English units used for test simulation 2 are consistent with units of example problem as described by Prudic and others (2004) and were not changed to conform to the Standard International units used elsewhere in this document. Abbreviations: $\mathrm{ft} / \mathrm{s}$, foot per second; $\mathrm{ft}$, foot; $\mathrm{ft}^{3}$, cubic foot]

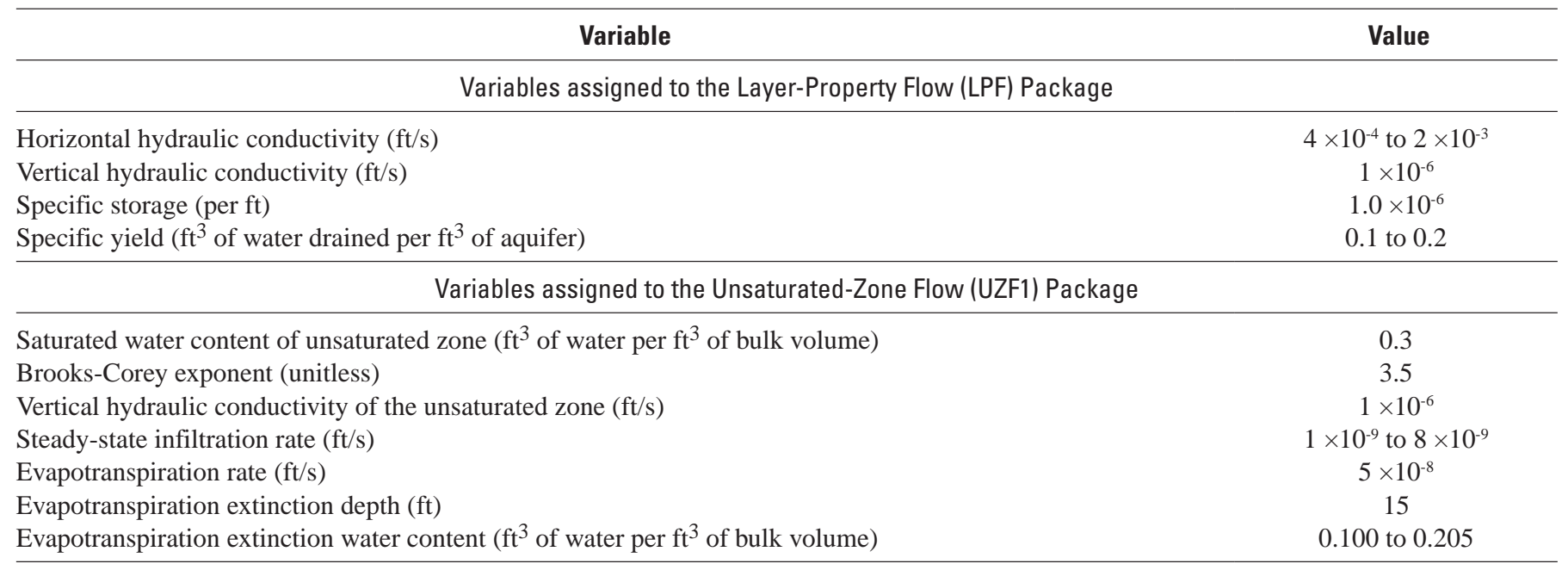


Table 7. Computed ground-water budget for test simulation 2 .

[English units used for test simulation 2 are consistent with units of example problem as described by Prudic and others (2004) and were not changed to conform to the Standard International units used elsewhere in this document. All units are in cubic foot per second, rounded to nearest tenth]

\begin{tabular}{|c|c|c|c|c|c|c|}
\hline & \multirow{2}{*}{$\begin{array}{c}\begin{array}{c}\text { Steady } \\
\text { state }\end{array} \\
\text { Period } 1\end{array}$} & \multicolumn{5}{|c|}{ End of stress } \\
\hline & & Period 3 & Period 5 & Period 7 & Period 9 & Period 12 \\
\hline \multicolumn{7}{|c|}{ Inflow } \\
\hline Leakage from streams & 43.7 & 42.8 & 42.0 & 42.4 & 42.7 & 42.9 \\
\hline Recharge & 8.5 & 16.0 & 8.3 & 9.3 & 11.4 & 11.3 \\
\hline Underflow beneath streams entering basin & .2 & .2 & .2 & .2 & .2 & .2 \\
\hline Total Inflow & 52.4 & 59.0 & 50.5 & 51.9 & 54.3 & 54.4 \\
\hline \multicolumn{7}{|c|}{ Outflow } \\
\hline Wells & 20.0 & 10.0 & 30.0 & 20.0 & 10.0 & 0.0 \\
\hline Evapotranspiration from ground water & 19.5 & 13.6 & 17.4 & 17.0 & 17.2 & 18.6 \\
\hline Leakage to streams & 12.6 & 14.1 & 14.2 & 13.9 & 13.9 & 13.6 \\
\hline Underflow beneath stream exiting basin & .3 & .3 & .3 & .3 & .3 & .3 \\
\hline Ground-water seepage to land surface & .0 & .0 & .0 & .0 & .0 & .0 \\
\hline Total outflow & 52.4 & 38.0 & 61.9 & 51.2 & 41.4 & 32.5 \\
\hline Removed from storage & .0 & .2 & 14.9 & 5.5 & .8 & .8 \\
\hline Added to storage & .0 & 21.1 & 3.6 & 6.3 & 13.8 & 22.8 \\
\hline
\end{tabular}

Table 8. Computed unsaturated-zone budget for test simulation 2 .

[English units used for test simulation 2 are consistent with units of example problem as described by Prudic and others (2004) and were not changed to conform to the Standard International units used elsewhere in this document. All units are in cubic foot per second, rounded to nearest tenth]

\begin{tabular}{|c|c|c|c|c|c|c|}
\hline & \multirow{2}{*}{$\begin{array}{c}\begin{array}{c}\text { Steady } \\
\text { state }\end{array} \\
\text { Period } 1\end{array}$} & \multicolumn{5}{|c|}{ End of stress } \\
\hline & & Period 3 & Period 5 & Period 7 & Period 9 & Period 12 \\
\hline \multicolumn{7}{|c|}{ Inflow } \\
\hline Infiltration & 8.5 & 84.8 & 42.4 & 25.4 & 25.4 & 8.5 \\
\hline \multicolumn{7}{|c|}{ Outflow } \\
\hline Unsaturated-zone evapotranspiration & - & 109.5 & 61.8 & 69.4 & 58.1 & 29.8 \\
\hline Ground-water recharge & 8.5 & 16.0 & 8.3 & 9.3 & 11.4 & 11.3 \\
\hline Storage change & 0.0 & -40.7 & -27.7 & -53.3 & -44.1 & -32.6 \\
\hline
\end{tabular}




\section{Implementation of UZF1 With MODFLOW-2005}

The UZF1 Package comprises 13 subroutines and one Fortran module that are used with the Ground-Water Flow (GWF) Process of MODFLOW-2005 (Harbaugh, 2005). Each subroutine or module incorporated in the main listing of MODFLOW-2005 is identified first by the Ground-Water Flow (GWF2) Process, followed by the UZF1 Package, and then followed by the division of procedures used in MODFLOW-2005. The Fortran module is used to share and store data. Memory allocation, reading input data and initialization of variables, formulating characteristic and finitedifference equations, and computing mass balances occur within GWF2UZF1AR, GWF2UZF1RP, GWF2UZF1FM, and GWF2UZF1BD subroutines, respectively. The subroutine GWF2UZF1VKS was added to define the saturated vertical hydraulic conductivity in the unsaturated zone, either as a variable read into the UZF1 Package in the GWF2UZF1RP subroutine or obtained from the LPF or Block-Centered Flow (BCF) Packages (Harbaugh, 2005). In addition to the subroutines called from the main program, several new subroutines were included in the UZF1 Package for routing kinematic waves through the unsaturated zone. These subroutines are UZF1FLOW2, LEADWAVE2, and TRAILWAVE2. The subroutine GWF2UZF1OLF was included to add ground-water discharge to land surface and overland flow to streams and lakes. The subroutine TRANSPIRATION was included to account for ET loss from the unsaturated zone. Finally, memory deallocation, setting pointer for all data for the package, and saving pointer locations occurs within GWF2UZF1DA, GWF2UZF1PNT, and GWF2UZF1PSV, respectively.

Additionally, the MAIN program of MODFLOW-2005 has been modified to designate "UZF" in position 56 in CUNIT. Whenever "UZF" is used at the beginning of a line in the NAME file, the program will use the specified unit number and file name to obtain information for the UZF1 Package. Output from the UZF1 Package can be printed to any or all of (1) the main listing file; (2) a separate listing file; (3) separate files for each specified cell that provides a time series of selected information; and (4) separate files for budget items summed for all model cells.

The UZF1 Package has been programmed to apply infiltration to a designated underlying cell. If the water level in the underlying cell becomes less than the bottom elevation of the cell, the cell becomes inactive. When this happens, unsaturated flow will be routed vertically to the uppermost active cell. However, the unsaturated zone hydraulic properties remain unchanged even if the properties change across model layers. If all cells in the vertical column are inactive, no interaction with ground water is allowed and water is not routed through the unsaturated zone and a warning is printed in the main output file.

\section{Summary}

The U.S. Geological Survey modular finite-difference ground-water flow model (MODFLOW-2005) has been used to model surface-water and ground-water interaction over a wide range of spatial scales. The capability to simulate vertical unsaturated flow was added to MODFLOW-2005 for the purpose of simulating the delay between infiltration at land surface and recharge at the water table. Unsaturated flow is simulated using a kinematic-wave approximation of Richards' equation and assuming one-dimensional gravity-driven vertical flow. The method of characteristics is used to solve the kinematic-wave approximation. The approach simulates flow and storage in the unsaturated zone and time-delayed recharge, while maintaining the applicability of MODFLOW-2005 to basin-scale problems.

Unsaturated flow is simulated independently of saturated flow within each model cell in which the water table is below land surface. The relation between the unsaturated hydraulic conductivity and water content in the unsaturated zone is defined on the basis of the Brooks-Corey function. Variables used to simulate unsaturated flow include saturated and initial water content, saturated vertical hydraulic conductivity, and the Brooks-Corey exponent. Additionally, the residual water content is approximated by the aquifer specific retention in the Brooks-Corey function. Specific retention is calculated as the porosity represented by the saturated water content minus specific yield. These variables can be different for each MODFLOW column of cells but cannot change between model layers.

The maximum infiltration rate (flow per unit area) across the land surface is limited to the vertical saturated hydraulic conductivity. Recharge is added to ground water only when water in the unsaturated zone drains to the water table. This differs from the standard Recharge Package, in which the recharge rate must be determined separately from MODFLOW. When the water table rises, the quantity of water stored in the unsaturated zone above the residual water content is added to recharge. Thus, the water table can rise rapidly when the amount of water stored in the unsaturated zone is at or near saturation. A water budget for the unsaturated zone is tracked independently of the ground-water budget in MODFLOW.

Evapotranspiration may be simulated over a specified depth in the unsaturated zone. The volumetric rate of evapotranspiration is dependent on the volume of water stored in the unsaturated zone above the specified extinction depth and extinction water content. Evapotranspiration also may be supplied by ground water when the water table is above the specified extinction depth. Variables that must be specified to simulate evapotranspiration include the evapotranspiration demand rate, the extinction depth, and the extinction water content. 
Ground water may discharge to the land surface when using the UZF1 Package. This water may be added to a specified stream segment in the Streamflow-Routing (SFR2) Package or to a specified lake in the Lake (LAK3) Package, provided the packages are being used in the simulation. Water discharging to land surface is added to stream segments or lakes without delay during each time step, regardless of the distance between the cell where ground water is discharged to the nearest stream segment or lake.

Results from the kinematic-wave approximation in the UZF1 Package were compared with results from U.S. Geological Survey's Variably-Saturated Two-Dimensional Flow and Transport (VS2DT) Model that solves Richards' equation. The test simulation demonstrates the capability of the UZF1 Package to simulate the advancement of a wetting front assuming three different rates of evapotranspiration. The simulation was in good agreement in the magnitude and downward progression of the wetting front with respect to the results from the VS2DT. An application to a $27 \mathrm{~km}^{2}$ watershed was used to demonstrate the capabilities of the UZF1 Package. A 1-year transient simulation in which infiltration and evapotranspiration demand changed daily demonstrated that simulating flow through the unsaturated zone is important for estimating recharge. Years in which infiltration rates exceed the mean annual ET rate may increase unsaturated-zone and ground-water storage, even in relatively poorly permeable rocks, and can result in increased discharge to streams that may extend well beyond the period of infiltration. A second and simpler problem is included to provide an example of the input-file structure and model output and to provide testing of the package after installation.

\section{References Cited}

Abbott, M.B., 1966, An introduction to the method of characteristics: New York, Elsevier Publishing Company, Inc., $243 \mathrm{p}$.

Brooks, R.H., and Corey, A.T., 1966, Properties of porous media affecting fluid flow: American Society of Civil Engineers, Journal of Irrigation and Drainage, v. 101, p. 85-92.

Charbeneau, R.J., 1984, Kinematic models for soil moisture and solute transport: Water Resources Research, v. 20, no. 6, p. 699-706.

Chen, ZhiQiang, Govindaraju, R.S., and Kavvas, M.L., 1994, Spatial averaging of unsaturated flow equations under infiltration conditions over areally heterogeneous fields-1. Development of models: Water Resources Research, v. 30, no. 2, p. 523-534.

Childs, E.C., and Bybordi, M., 1969, The vertical movement of water in stratified porous material, 1. Infiltration: Water Resources Research, v. 5, no. 2, p. 446-459.

Colbeck, S.C., 1972, A theory of water percolation in snow: Journal of Glaciology, v. 2, no. 63, p. 369-385.
Fenske, J.P., and Prudic, D.E., 1998, Development of HMS/ MODFLOW for simulation of surface and groundwater flow, in Poeter, Eileen, Zheng, Chunmiao, and Hill, Mary, eds., MODFLOW '98: Golden, Colo., Colorado School of Mines, October, 4-8, 1998, Proceedings, v. 1, p. 463-470.

Freeze, R.A., 1971, Three-dimensional, transient, saturatedunsaturated flow in a groundwater basin: Water Resources Research, v. 7, no. 5, p. 153-171.

Harbaugh, A.W., 2005, MODFLOW-2005, the U.S. Geological Survey modular ground-water model-the Ground-Water Flow Process: U.S. Geological Survey Techniques and Methods 6-A16, variously paginated.

Harbaugh, A.W., Banta, E.R., Hill, M.C., and McDonald, M.G., 2000, MODFLOW-2000, the U.S. Geological Survey modular ground-water model-modularization concepts and the ground-water flow process: U.S. Geological Survey Open-File Report 00-92, 121 p.

Healy, R.W., 1990, Simulation of solute transport in variably saturated porous media with supplemental information on modification of the U.S. Geological Survey's computer program VS2D: U.S. Geological Survey Water-Resources Investigations Report 90-4025, 125 p.

McDonald, M.G., and Harbaugh, A.W., 1988, A modular three-dimensional finite-difference ground-water flow model: U.S. Geological Survey Techniques of WaterResources Investigations, Book 6, Chapter A1, 586 p.

Mantoglou, Aristotelis, 1992, A theoretical approach for modeling unsaturated flow in spatially variable soilsEffective flow models in finite domains and nonstationarity: Water Resources Research, v. 28, no. 1, p. 251-267.

Mast, M.A., and Clow, D.W., 2000, Environmental characteristics and water quality of hydrologic benchmark network stations in the Western United States, 1963-95: U.S. Geological Survey Circular 1173-D, 114 p.

Mein, R.G., and Larson, C.L., 1973, Modeling infiltration during a steady rain: Water Resources Research, v. 9, no. 2, p. 384-394.

Meinzer, O.E., 1923, Outline of ground-water hydrology, with definitions: U.S. Geological Survey Water-Supply Paper 494, 71 p.

Merritt, M.L., and Konikow, L.F., 2000, Documentation of a computer program to simulate lake-aquifer interaction using the MODFLOW ground-water flow model and the MOC3D solute-transport model: U.S. Geological Survey WaterResources Investigations Report 00-4167, 146 p.

Niswonger, R.G., and Prudic, D.E., 2004, Modeling variably saturated flow using kinematic waves in MODFLOW, in Hogan, J.F., Phillips, F.M., and Scanlon, B.R., eds., Groundwater Recharge in a Desert Environment-The Southwestern United States: Washington, D.C., American Geophysical Union, Water Science and Application Series, v. 9, p. 101-112. 
Niswonger, R.G., and Prudic, D.E., 2006, Documentation of the Streamflow-Routing (SFR2) Package to include unsaturated flow beneath streams-A modification to SFR1: U.S. Geological Survey Techniques and Methods, Book 6, Chap. A13, 57 p.

Pikul, M.F., Street, R.L., and Remson, Irving, 1974, A numerical model based on coupled one-dimensional Richards and Boussinesq equations: Water Resources Research, v. 10, no. 2, p. 295-302.

Prudic, D.E., Konikow, L.F., and Banta, E.R., 2004, A new Streamflow-Routing (SFR1) Package to simulate streamaquifer interaction with MODFLOW-2000: U.S. Geological Survey Open-File Report 2004-1042, 95 p.

Refsgaard, J.C., and Storm, B., 1995, MIKE SHE, in Computer Models of Watershed Hydrology: Singh, V.P., ed., Highlands Ranch, Colo., Water Resources Publications, p. 809-846.
Smith, R.E., 1983, Approximate sediment water movement by kinematic characteristics: Soil Science Society of America Journal, v. 47, p. 3-8.

Smith, R.E., and Hebbert, R.H.B., 1983, Mathematical simulation of interdependent surface and subsurface hydrologic processes: Water Resources Research, v. 19, no. 4, p. 987-1001.

Smith, R.E., and Parlange, J.Y., 1978, A parameter-efficient hydrologic infiltration model: Water Resources Research, v. 14 , no. 3, p. 533-538.

Sophocleous, Marious, and Perkins, S.P., 2000, Methodology and application of combined watershed and groundwater model in Kansas: Journal of Hydrology, v. 236, p. 185-201. Thoms, R.B., Johnson, R.L., and Healy, R.W., 2006, User's Guide to the Variably Saturated Flow (VSF) Process for MODFLOW: U.S. Geological Survey Techniques and Methods Book 6, Chap. A18, 58 p. 


\section{Appendix 1: Data Input Instructions for the Unsaturated-Zone Flow (UZF1) Package}

\section{MODFLOW Name File}

Percolation of water through an unsaturated zone is activated by including a record in the MODFLOW name file using the file type (Ftype) "UZF" to indicate that relevant calculations are to be made in the model and to specify the related input data file. The UZF1 Package is compatible with MODFLOW-2005 (Harbaugh, 2005), but not with earlier versions of MODFLOW. The user can optionally specify unsaturated-zone water budgets and water content profiles for selected model cells by including a record in the MODFLOW name file using the file type (Ftype) "DATA" that specifies the relevant output data file name for each model cell. The row and column cell indices for each selected model cell are included in the UZF output file. Three types of information may be printed to the specified file for each model cell depending on the OUTTYPE option specified. The three OUTTYPE options are: option 1 prints volumes of water entering, leaving, and stored in the unsaturated zone; option 2 prints volumes and rates for water entering, leaving, and stored within the unsaturated zone; and option 3 prints the water content profile between land surface and the water table. Additionally, a time series of infiltration, unsaturated zone evapotranspiration, recharge, and ground-water discharge summed over the model domain may be printed to a specified file.

\section{Unsaturated-Zone Flow Package Input Data}

The UZF1 Package input file consists of items numbered from 0 through 16, each consisting of one or more records. These data are used to specify information about the hydraulic properties of the unsaturated zone, the infiltration rate, evapotranspiration, and certain output control options. All input variables are read using free format unless indicated otherwise. In free format, variables are separated by one or more spaces or by a comma and optionally one or more spaces. A blank field cannot be used to set a variable value to zero. Units of length $(\mathrm{L})$ and time $(\mathrm{T})$ are used to define the dimensions of each variable.

The UZF1 Package relies on the specific yield values as specified in the Layer-Property Flow (LPF) Package or the BlockCentered Flow (BCF) Package. Thus, the option for unsaturated flow is only available when either the LPF or BCF Package is used in the simulation. When the option to use vertical hydraulic conductivity in the LPF Package is specified, the layer(s) that contain cells where unsaturated flow will be simulated must be specified as convertible. That is, the variable LAYTYP specified in the LPF Package must not be equal to zero, otherwise the model will print an error and stop execution. The variable VKA in LPF may be specified as the ratio of horizontal to vertical hydraulic conductivity (LAYVKA is not zero) or as the vertical hydraulic conductivity (LAYVKA=0). When using the BCF Package, the right digit of LTYPE (LAYCON) must be greater or equal to one or the model will print an error and stop execution. Neither parameter estimation nor solute transport can be simulated with the UZF1 Package.

\section{For Each Simulation}

0. Data: [\#Text]

Text A character variable (up to 199 characters) that is printed when the file is read. The "\#”" character must be in column 1, and, accordingly, the variable starts in column 2. Any characters can be included in Text.

Note 1: Item 0 can be repeated multiple times.

1. Data: NUZtOP IUZFOPt IRUNFLG IETFLG IUZFCB1 IUZFCB2 NTRAIL2 NSETS2 NUZGAG SURFDEP

NUZTOP An integer value used to define which cell in a vertical column that recharge and discharge is simulated.

1 Recharge to and discharge from only the top model layer. This option assumes land surface is defined as top of layer 1.

2 Recharge to and discharge from the specified layer in variable IUZFBND. This option assumes land surface is defined as top of layer specified in IUZFBND.

3 Recharge to and discharge from the highest active cell in each vertical column. Land surface is determined as top of layer specified in IUZFBND. A constant head node intercepts any recharge and prevents deeper percolation. 
IUZFOPT An integer value equal to 0,1 , or 2 . A value of zero indicates that flow will not be routed through the unsaturated zone, rather infiltration will be applied directly to the saturated zone. A value of 1 indicates that the vertical hydraulic conductivity will be specified within the UZF1 Package input file using array VKS. A value of 2 indicates that the vertical hydraulic conductivity will be specified within either the BCF or LPF Package input file.

IRUNFLG An integer value that specifies whether ground water that discharges to land surface will be routed to stream segments or lakes as specified in the IRUNBND array (IRUNFLG not equal to zero) or if ground-water discharge is removed from the model simulation and accounted for in the ground-water budget as a loss of water (IRUNFLG=0). The Streamflow-Routing (SFR2) and(or) the Lake (LAK3) Packages must be active if IRUNFLG is not zero.

IETFLG An integer value that specifies whether or not evapotranspiration (ET) will be simulated. ET will not be simulated if IETFLG is zero, otherwise it will be simulated.

IUZFCB1 An integer value used as a flag for writing ground-water recharge, ET, and ground-water discharge to land surface rates to a separate unformatted file using subroutine UBUDSV. If IUZFCB1>0, it is the unit number to which the cell-by-cell rates will be written when "SAVE BUDGET" or a non-zero value for ICBCEL is specified in Output Control. If IUZFCB1 $\leq 0$, cell-by-cell rates will not be written to a file.

IUZFCB2 An integer value used as a flag for writing ground-water recharge, ET, and ground-water discharge to land surface rates to a separate unformatted file using module UBDSV3. If IUZFCB2>0, it is the unit number to which cell-by-cell rates will be written when "SAVE BUDGET" or a non-zero value for ICBCFL is specified in Output Control. If IUZFCB $\leq 0$, cell-by-cell rates will not be written to file.

NTRAIL2 An integer value equal to the number of trailing waves used to define the water-content profile following a decrease in the infiltration rate. The number of trailing waves varies depending on the problem, but a range between 10 and 20 is usually adequate. More trailing waves may decrease mass-balance error and will increase computational requirements and memory usage. This variable is not specified if IUZFOPT is zero or less.

NSETS2 An integer value equal to the number of wave sets used to simulate multiple infiltration periods. The number of wave sets should be set to 20 for most problems involving time varying infiltration. The total number of waves allowed within an unsaturated zone cell is equal to NTRAIL 2 *NSETS2. An error will occur if the number of waves in a cell exceeds this value. This variable is not specified if IUZFOPT is zero or less.

NUZGAG An integer value equal to the number of cells (one per vertical column) that will be specified for printing detailed information on the unsaturated zone water budget and water content. A gage also may be used to print the budget summed over all model cells.

SURFDEP A real value equal to the average undulation depth within a finite-difference cell.

Note 2: The variables NTRAIL2 and NSETS2 are used for dimensioning arrays.

2. Data: [IUZFBND (NCOL, NROW) ] -- U2DINT

IUZFBND An array of integer values used to define the aerial extent of the active model in which recharge and discharge will be simulated.

\section{If IRUNFLG > 0: Read item 3}

3. Data: [IRUNBND (NCOL, NROW) ] -- U2DINT

IRUNBND An array of integer values used to define the stream segments within the Streamflow-Routing (SFR2) Package or lake numbers in the Lake (LAK3) Package that overland runoff from excess infiltration and ground-water discharge to land surface will be added. A positive integer value identifies the stream segment and a negative integer value identifies the lake number. 


\section{IF IUZOPT = 1: Read item 4.}

4. Data: [VKS (NCOL, NROW) ] -- U2DREL

VKS An array of positive real values used to define the saturated vertical hydraulic conductivity of the unsaturated zone $\left(\mathrm{LT}^{-1}\right)$.

Note 3: Vertical hydraulic conductivity is optional when either the LPF or BCF Package is used to define vertical hydraulic conductivity of cells ( IUZFOPT=2).

5. Data: [EPS (NCOL, NROW)] -- U2DREL

EPS An array of positive real values for each model cell used to define the Brooks-Corey epsilon of the unsaturated zone. Epsilon is used in the relation of water content to hydraulic conductivity (Brooks and Corey, 1966). This variable is not specified if IUZFOPT is zero or less.

6. Data: [THTS (NCOL, NROW)]-- U2DREL

THTS An array of positive real values used to define the saturated water content of the unsaturated zone in units of volume of water to total volume $\left(\mathrm{L}^{3} \mathrm{~L}^{-3}\right)$. This variable is not specified if IUZFOPT is zero or less.

7. Data: [THTI (NCOL, NROW) ] -- U2DREL

THTI An array of positive real values used to define the initial water content for each vertical column of cells in units of volume of water at start of simulation to total volume $\left(\mathrm{L}^{3} \mathrm{~L}^{-3}\right)$. THT I should not be specified for steady-state simulations. This variable is not specified if IUZFOPT is zero or less.

\section{If NUZGAG>0: Item 8 is repeated NUZGAG times}

8. Data: $\{$ IUZROW $\}$ IIUZCOL $\}$ IFTUNIT $\{$ IUZOPT $\}$

IUZROW An integer value equal to the row number of the cell that unsaturated-zone information will be printed for each time step. The variable is not used when IFTUNIT is negative.

IUZCOL An integer value equal to the column number of the cell that unsaturated-zone information will be printed for each time step. The variable is not used when IFTUNIT is negative.

IFTUNIT An integer value equal to the unit number of the output file. A positive value is for output of individual cells whereas a negative value is for output that is summed over all model cells. The summed output includes applied infiltration, runoff, actual infiltration, ground-water discharge to land surface, ET from the unsaturated zone, ET from ground water, recharge, and change in unsaturated-zone storage.

IUZOPT An integer value that is a flag for the type of expanded listing desired in the output file. The variable is not used when IFTUNIT is negative.

1 Prints time, ground-water head, and thickness of unsaturated zone, and cumulative volumes of infiltration, recharge, storage, change in storage and ground-water discharge to land surface.

2 Same as option 1 except rates of infiltration, recharge, change in storage, and ground-water discharge also are printed.

3 Prints time, ground-water head, thickness of unsaturated zone, followed by a series of depths and water contents in the unsaturated zone. This option cannot be used when IUZFOPT is zero or less.

Note 4: Item 8 must include exactly NUZGAG lines (records) of data. If NUZGAG > 1, it is permissible to repeat the same cell if a summary of volumes and rates and water contents are desired for a given cell. The records within item 8 can be listed in any order.

Note 5: A unique unit number for IFTUNIT must be specified for each line or record in item 8 and each number must match that used in the MODFLOW name file as Ftype "DATA" file types and file names (see Harbaugh, 2005). 


\section{For Each Stress Period}

9. Data: NUZF1

NUZF1 An integer value for reusing or reading infiltration rates that can change each stress period. If NUZF $1 \geq 0$, then infiltration rates at land surface are specified. If NUZF $1<0$, then infiltration rates from the previous stress period are used.

\section{If NUZF1 > 0:}

10. Data: [FINF (NCOL, NROW)] - U2DREL

FINF An array of positive real values used to define the infiltration rates $\left(\mathrm{LT}^{-1}\right)$ at land surface for each vertical column of cells.

Note 6: If FINF is specified as being greater than the vertical hydraulic conductivity then FINF is set equal to the vertical unsaturated hydraulic conductivity. Excess water is routed to streams or lakes when IRUNF LG is not zero, and if SFR2 or LAK3 is active.

\section{If IETFLG > 0: Read Items 11 through 16}

11. Data: NUZF2

NUZF2 An integer value for reusing or reading ET demand rates that can change each stress period. If NUZF $2 \geq 0$, then ET demand rates are specified. If NUZF $2<0$, then ET demand rates from the previous stress period are used.

If NUZF2 > 0:

12. Data: [PET (NCOL, NROW)] - U2DREL

PET An array of positive real values used to define the ET demand rates $\left(\mathrm{L}^{1} \mathrm{~T}^{-1}\right)$ within the ET extinction depth interval for each vertical column of cells.

13. Data: NUZF3

NUZF 3 An integer value for reusing or reading ET extinction depths that can change each stress period. If NUZF $3 \geq 0$, then ET extinction depths are specified. If $\operatorname{NUZF} 3<0$, then depths from the previous stress period are used.

\section{If NUZF3 > 0:}

14. Data: [EXTDP (NCOL, NROW)] - U2DREL

EXTDP An array of positive real values used to define the ET extinction depths.

Note 7: The quantity of ET removed from a cell is limited by the volume of water stored in the unsaturated zone above the extinction depth. If ground water is within the ET extinction depth, then the rate removed is based on a linear decrease in the maximum rate at land surface and zero at the ET extinction depth. The linear decrease is the same method used in the Evapotranspiration Package (McDonald and Harbaugh, 1988, chap. 10).

15. Data: NUZF4

NUZF 4 An integer value for reusing or reading the extinction water content that can change each stress period. If NUZF $4 \geq 0$, then extinction water contents are specified. If $\operatorname{NUZF} 4<0$, then the extinction water contents from the previous stress period are used.

If NUZF $4>0$ :

16. Data: [EXTWC (NCOL, NROW) ] - U2DREL

EXTWC An array of positive real values used to define the extinction water content below which ET cannot be removed from the unsaturated zone. This variable is not specified if IUZFOPT is zero or less.

Note 8: EXTWC must have a value between (THTS-SY) and THTS, where Sy is the specific yield specified in either the LPF or BCF Package. 


\section{Appendix 2: Selected Input Datasets and Printed Results for Test Simulation 2}

Selected sections of several key input and output data files are shown below for test simulation 2-sometimes with annotations; gaps in the listings are indicated by an ellipsis. A complete set of the files is available for distribution over the Internet as discussed in the Preface. Contents of some files are enclosed in a border and explanations are noted outside of the border; for other files, explanations are sometimes included as comments following a semicolon on the line being explained. Some brief annotations were added to the selected output listings to help the reader understand the purpose of various sections of output. These annotations are written in bold italics. Font sizes in the following listings are sometimes reduced so that lines will fit within page margins. Information pertaining specifically to the UZF1 Package is highlighted by shading.

\section{Listing of Selected Input Data Sets for Test Simulation 2}

Following (enclosed in a border) are the contents of the MODFLOW name file for test simulation 2. Shading indicates input files in which values are used in the UZF1 Package and output files in which information from the UZF1 Package are printed or saved:

File name: UZFtest2.nam

\begin{tabular}{|c|c|c|c|}
\hline $\begin{array}{l}\text { LIST } \\
\text { BAS6 }\end{array}$ & $\begin{array}{r}9 \\
75\end{array}$ & $\begin{array}{l}\text { Out \UZFtest } 2 . \text { lst } \\
\text { Data\UZFtest } 2 . \text { ba } 6\end{array}$ & $\begin{array}{l}\leftarrow \text { Output file for MODFLOW } \\
\leftarrow \text { Input file for Basic Package }\end{array}$ \\
\hline LPF & 7 & Data\UZFtest2.lpf & $\leftarrow$ Input file for Layer-Property Flow Package \\
\hline DIS & 8 & Data \UZFtest2.dis & $\leftarrow$ Input file for Discretization file \\
\hline SIP & 13 & Data\UZFtest2.sip & $\leftarrow$ Input file for Strongly Implicit Procedure Package \\
\hline $\mathrm{OC}$ & 14 & Data\UZFtest $2.0 \mathrm{C}$ & $\leftarrow$ Input file for Output Control option \\
\hline SFR & 15 & Data\UZFtest2.sfr & $\leftarrow$ Input file for Streamflow-Routing Package \\
\hline WEL & 16 & Data\UZFtest2. wel & $\leftarrow$ Input file for Well Package \\
\hline GHB & 17 & Data\UZFtest2.ghb & $\leftarrow$ Input file for General-Head Boundary Package \\
\hline UZF & 19 & Data\UZFtest2.uzf & $\leftarrow$ Input file for Unsaturated-Zone Flow Package \\
\hline GAGE & 32 & Data\UZFtest2.gag & $\leftarrow$ Input file for Gage Package \\
\hline DATA & 58 & Out \UZFtest2hd. out & $\leftarrow$ output file for calculated heads \\
\hline DATA (BINARY) & 61 & Out \UZFtest2.uzfot & $\leftarrow$ Output file for recharge and ground-water discharge \\
\hline DATA & 65 & Out \UZFtest 2 .uzf1 & $\leftarrow$ Output file unsaturated zone cell 1 (row 3, column 6) \\
\hline DATA & 66 & Out \UZFtest 2 . uzf2 & $\leftarrow$ Output file unsaturated zone cell 2 (row 6, column 3 ) \\
\hline DATA & 67 & Out \UZFtest2.uzf3 & $\leftarrow$ Output file unsaturated zone cell 3 (row 10, column 5) \\
\hline DATA & 68 & Out \UzFtest $2 \cdot$ uzf 4 & $\leftarrow$ Output file of times series of unsaturated-zone water budgets \\
\hline DATA & 81 & Out \UZFtest2.flw & $\leftarrow$ Auxiliary output file for the Streamflow-Routing Package \\
\hline DATA & 83 & Out \UZFtest2.sg1 & $\leftarrow$ Output file for last reach in stream segment 1 \\
\hline DATA & 84 & Out \UZFtest $2 . \operatorname{sg} 2$ & $\leftarrow$ Output file for last reach in stream segment 2 \\
\hline DATA & 85 & Out \UZFtest2.sg3 & $\leftarrow$ Output file for last reach in stream segment 3 \\
\hline DATA & 86 & Out \UZFtest2.sg 4 & $\leftarrow$ Output file for last reach in stream segment 4 \\
\hline DATA & 87 & Out \UZFtest2.sg5 & $\leftarrow$ Output file for last reach in stream segment 5 \\
\hline DATA & 88 & Out \UZFtest2.sg6 & $\leftarrow$ Output file for last reach in stream segment 6 \\
\hline DATA & 89 & Out \UZFtest2.sg7 & $\leftarrow$ Output file for last reach in stream segment 7 \\
\hline DATA & 90 & Out \UZFtest2.sg8 & $\leftarrow$ Output file for last reach in stream segment 8 \\
\hline DATA & 91 & Out \UZFtest $2 \mathrm{dv} \cdot \mathrm{sg} 9$ & $\leftarrow$ Output file for first reach in stream segment 3 \\
\hline$\uparrow$ & $\uparrow$ & $\uparrow$ & \\
\hline 1 & 2 & 3 & \\
\hline \multicolumn{4}{|c|}{${ }^{1}$ Ftype (the type of file). } \\
\hline \multicolumn{4}{|c|}{${ }^{2}$ Unit number. } \\
\hline & & & \\
\hline
\end{tabular}


Following (enclosed in a border) are the contents of the Basic Package input file for test simulation 2; explanations are noted outside of border:

File name: UzFTest2.ba 6

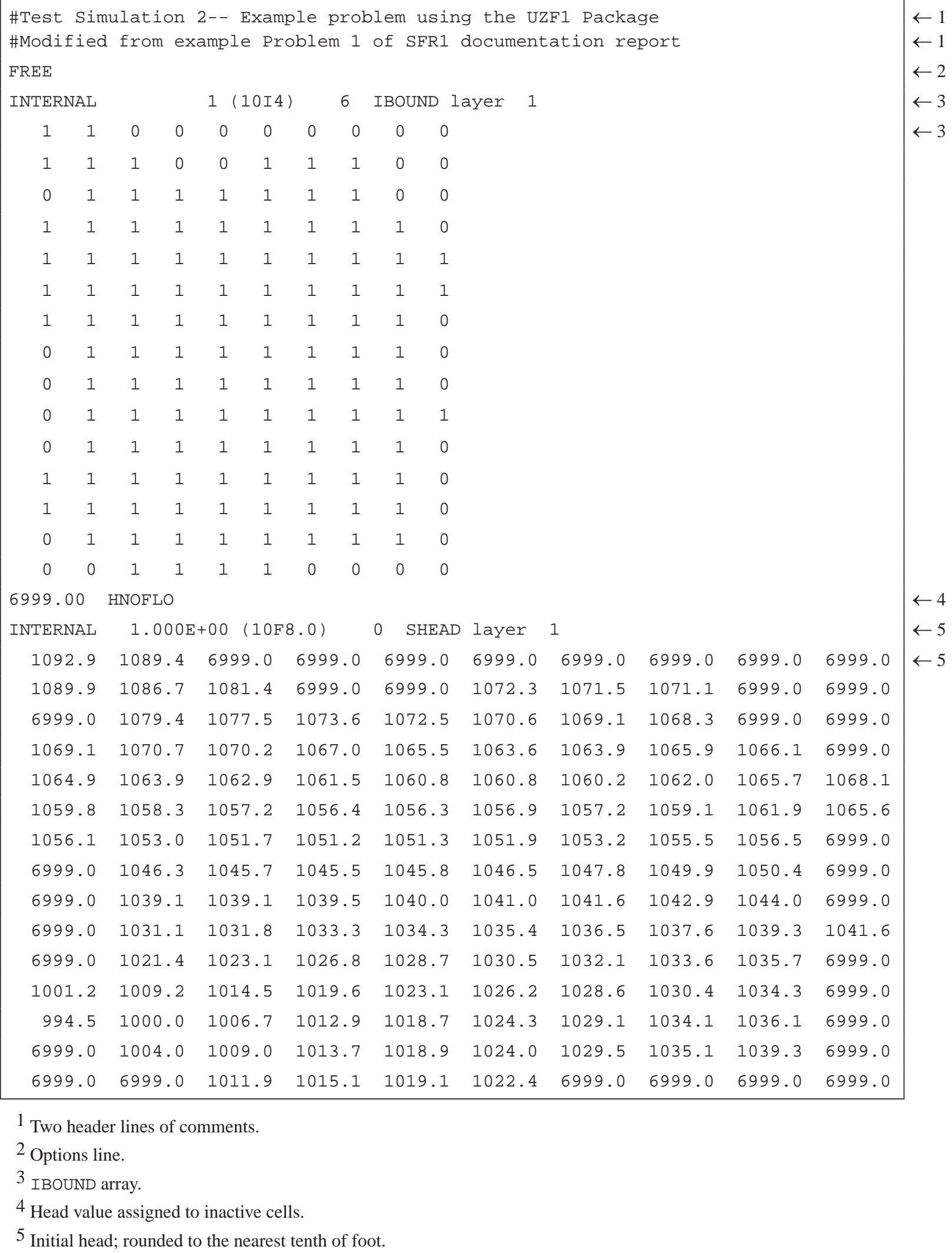

1 Two header lines of comments.

2 Options line.

3 IBOUND array.

${ }^{4}$ Head value assigned to inactive cells.

5 Initial head; rounded to the nearest tenth of foot. 
Following (enclosed in a border) are the contents of the Discretization input file for test simulation 2; explanations are noted outside of border:

File name: UZFtest2.dis

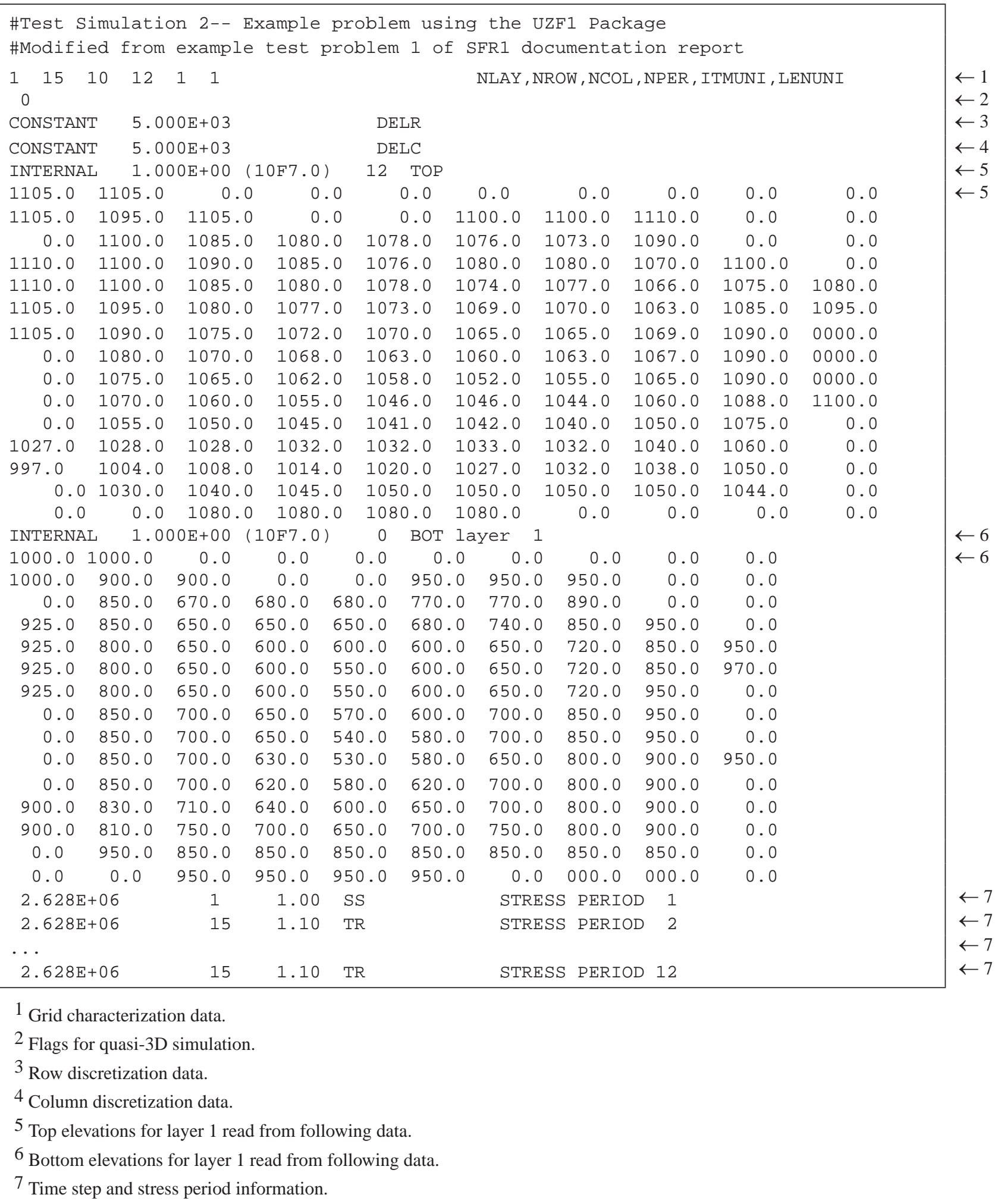


Following (enclosed in a border) are the contents of the Layer-Property Flow Package input file for test simulation 2; explanations are noted outside of border. Shading indicates that the specific yield specified within the Layer-Property Flow Package is used to calculate the residual water content in the UZF1 Package.

File name: UZFtest2.lpf

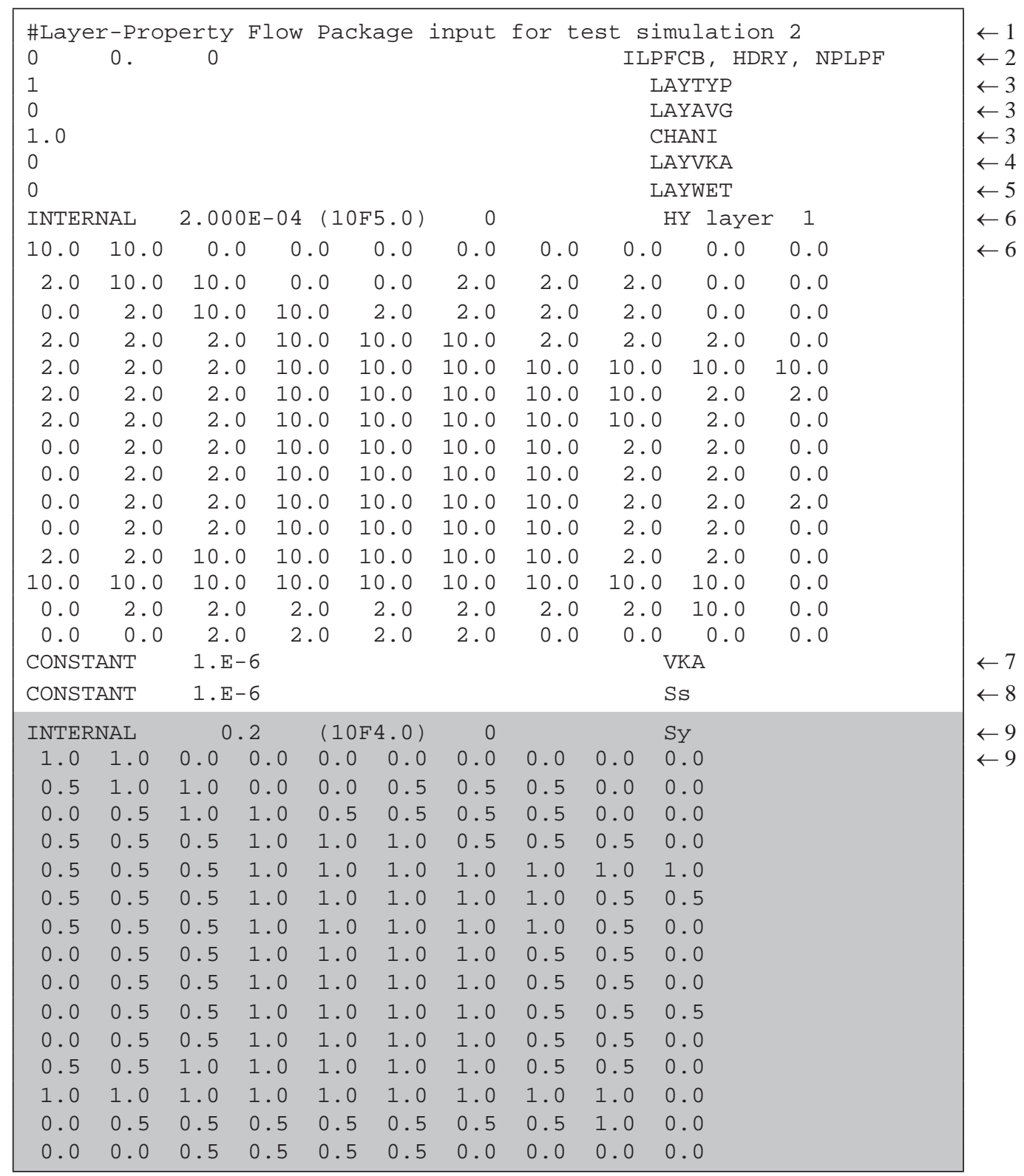

1 Comment lines.

2 Flag for cell-by-cell flow terms; head in cell for wet-dry simulations; and flag related to wet-dry simulations.

3 Layer type; method for computing transmissivity; and horizontal anisotropy.

${ }^{4}$ Flag to determine vertical hydraulic conductivity.

5 Flag to determine if rewetting is active.

6 Hydraulic conductivity data for layer 1 read from following data.

7 Ratio of vertical to horizontal hydraulic conductivity.

8 Specific storage for layer 1.

${ }^{9}$ Specific yield for layer 1 . 
Following (enclosed in a border) are the contents of the Unsaturated-Zone Flow Package input file for test simulation 2; explanations are noted outside of border:

File name: UzFtest2.uzf

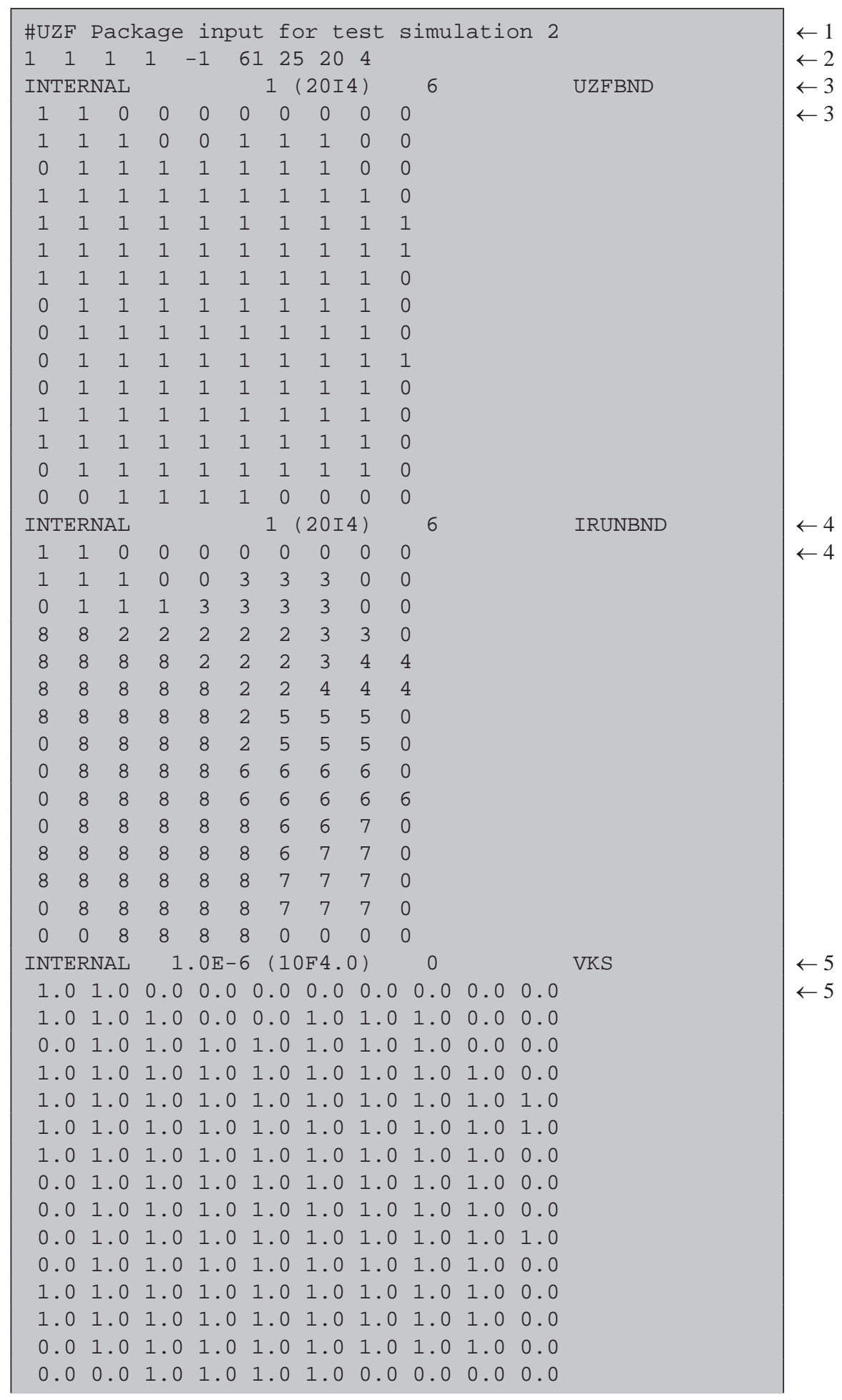


File name: UZFtest2.uzf (continued)

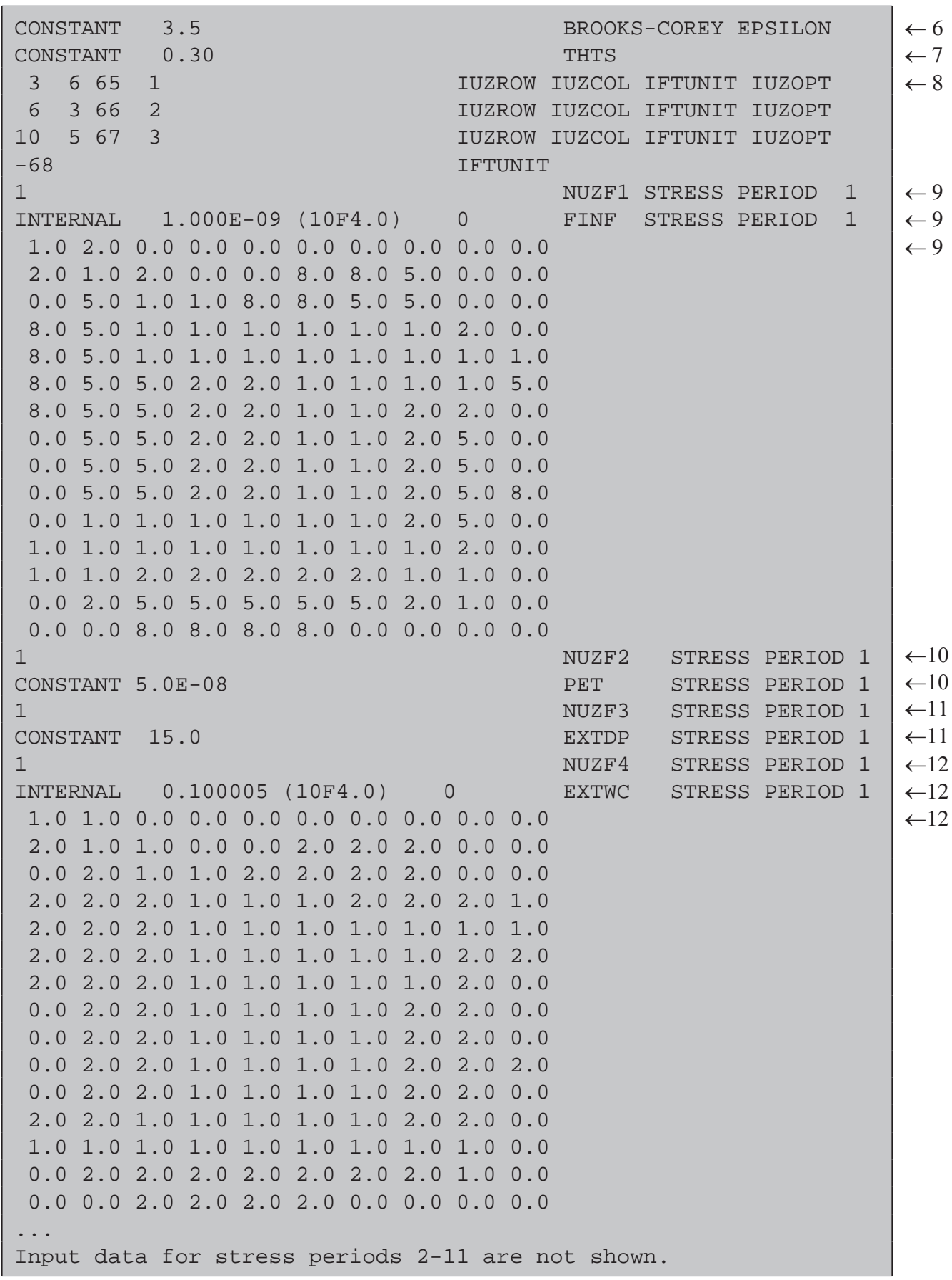


File name: UZFtest2.uzf (continued)

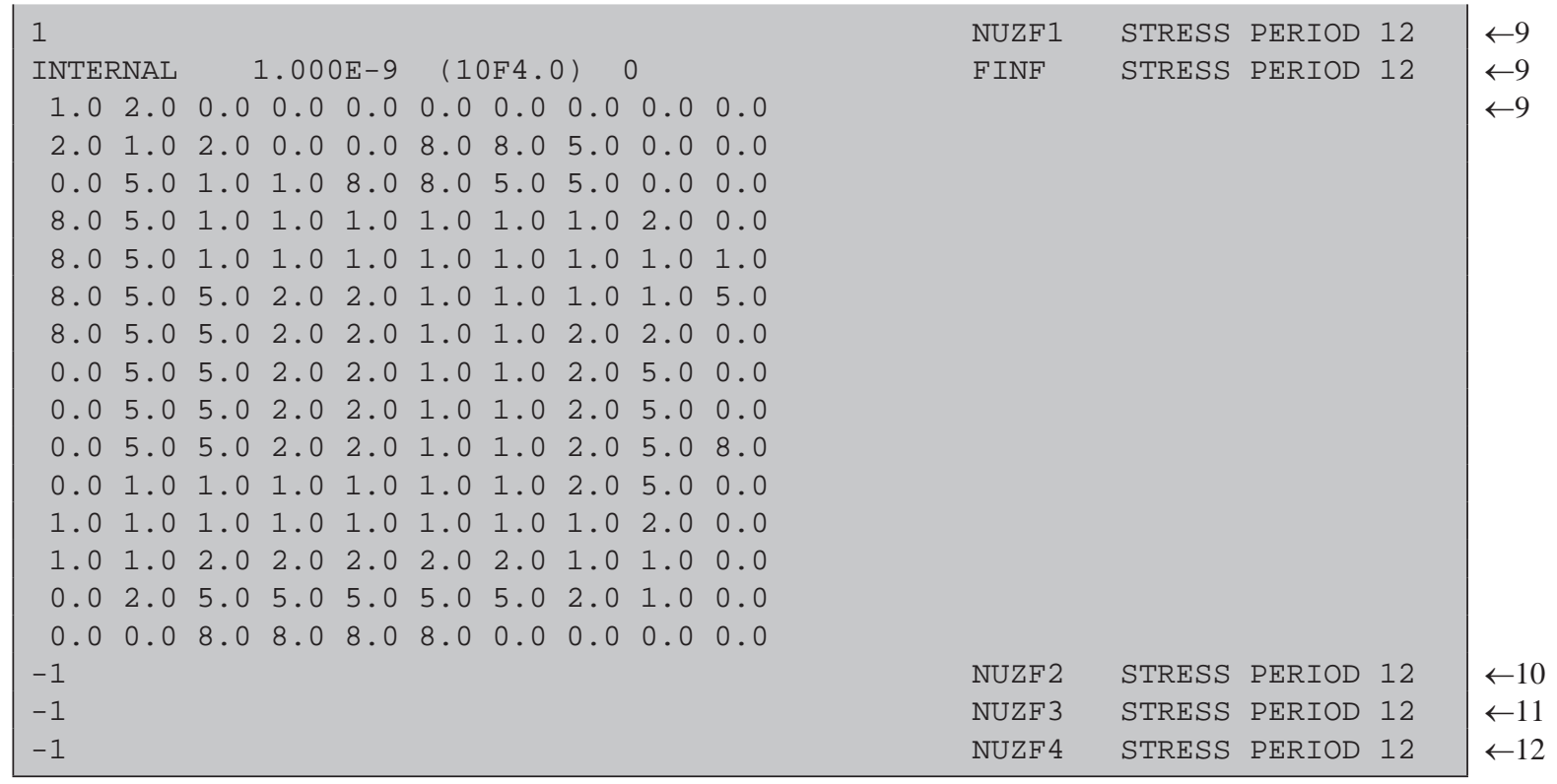

1 Comment lines.

2 Flags for unsaturated flow options; print options; number of trailing waves; trailing sets; and the number of unsaturated zone cells for printing time-series data.

3 Boundary array for unsaturated flow.

4 Array that specifies stream segments for adding ground-water discharge to streams.

5 Vertical hydraulic conductivity of the unsaturated zone.

6 Brooks-Corey exponent.

7 Saturated water content. Note-no THT I because the first stress period is steady state.

8 Row and column indices; file unit number; and gage option for printing unsaturated flow results.

9 Applied infiltration rate.

10 Evapotranspiration demand rate.

11 Evapotranspiration extinction depth.

12 Evapotranspiration extinction water content. 
Following (enclosed in a border) are the contents of the Well Package input file for test simulation 2; explanations are noted outside of border:

File name: UzFtest 2 .wel

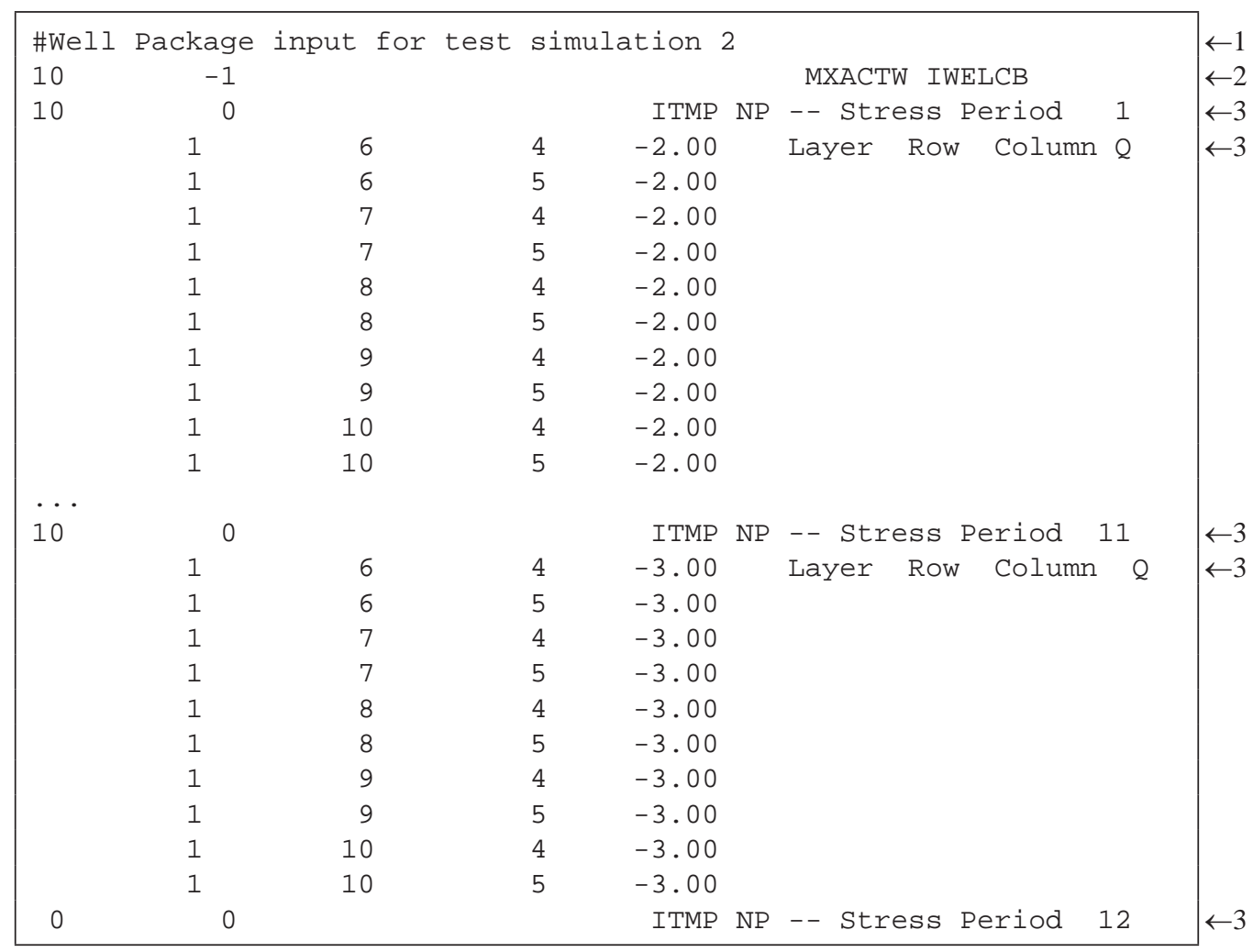

1 Comment lines.

2 Maximum number of wells used during stress period; and flag for printing.

3 Number of non-parameter wells read for current stress period; number of parameters used in the current stress period; and layer, row, and column for well and pumping rate.

Following (enclosed in a border) are the contents of the Strongly Implicit Procedure Package input file for test simulation 2; explanations are noted outside of border:

File name: UZFtest2.sip

\begin{tabular}{|rrrlll}
\hline 300 & 5 & & MXITER & NPARM \\
1.0 & $2.0 \mathrm{E}-04$ & 1 & 0.0 & 1 & $\leftarrow 1$ \\
\hline
\end{tabular}

1 Maximum iterations; and number of iteration parameters.

2 Acceleration parameter; head change criterion; flag for seed; seed; and printout interval for SIP. 
Following (enclosed in a border) are the contents of the General-Head Boundary Package input file for test simulation 2; explanations are noted outside of border:

File name: UzFtest2.ghb

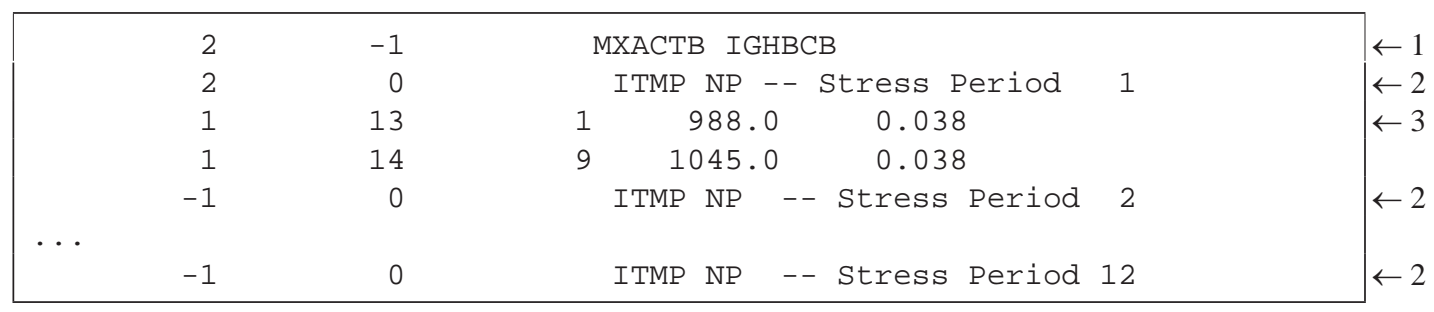

${ }^{1}$ Maximum number of general-head boundary cells; and unit number for storing cell-by-cell flow terms.

2 Read flags for stress period.

3 General-head boundary cells for stress period 1 .

Following (enclosed in a border) are the contents of the Streamflow-Routing Package input file for test simulation 2; explanations are noted outside of border:

File name: UZFtest2.sfr

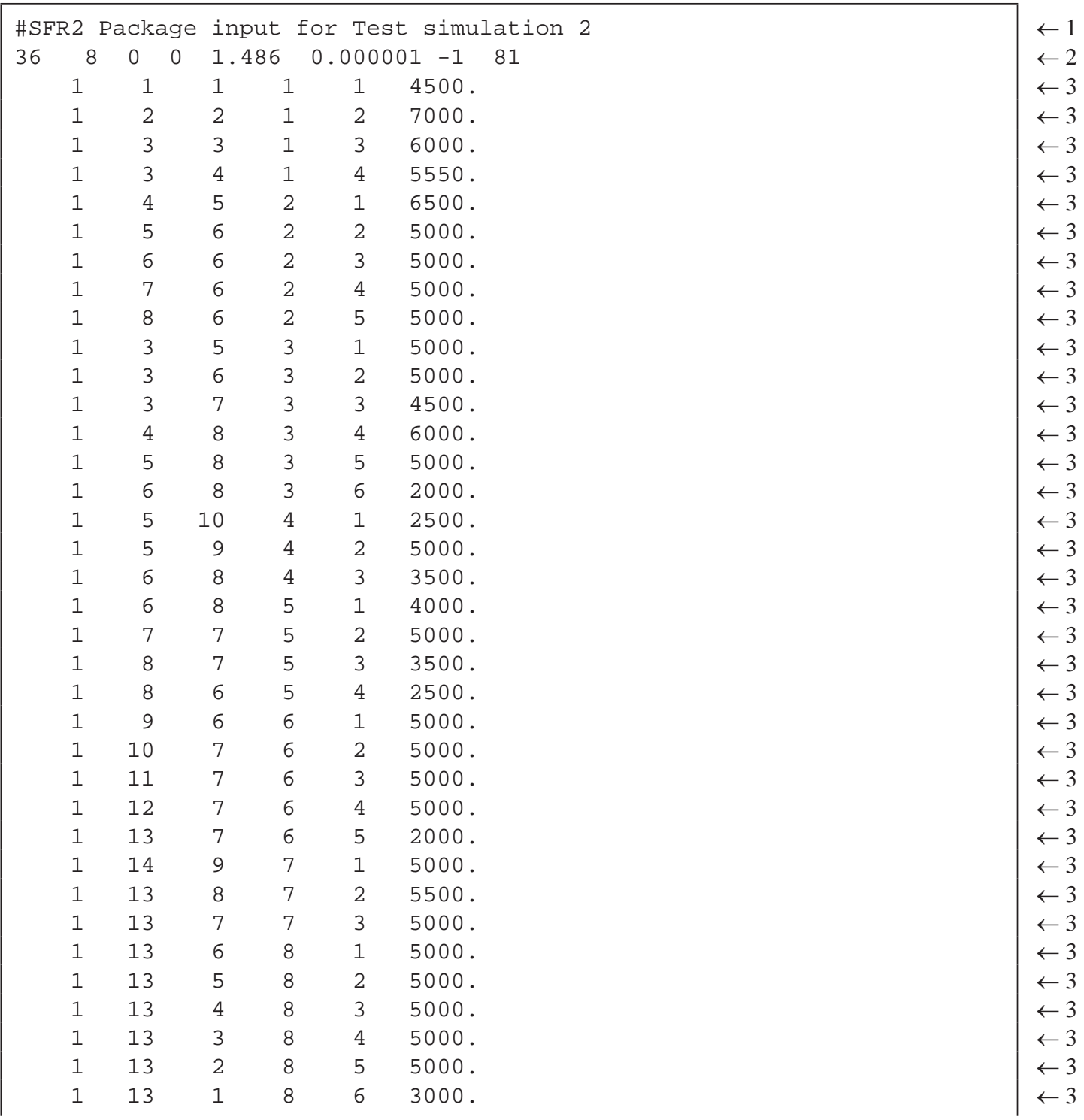


File name: UZFtest2.sfr (continued)

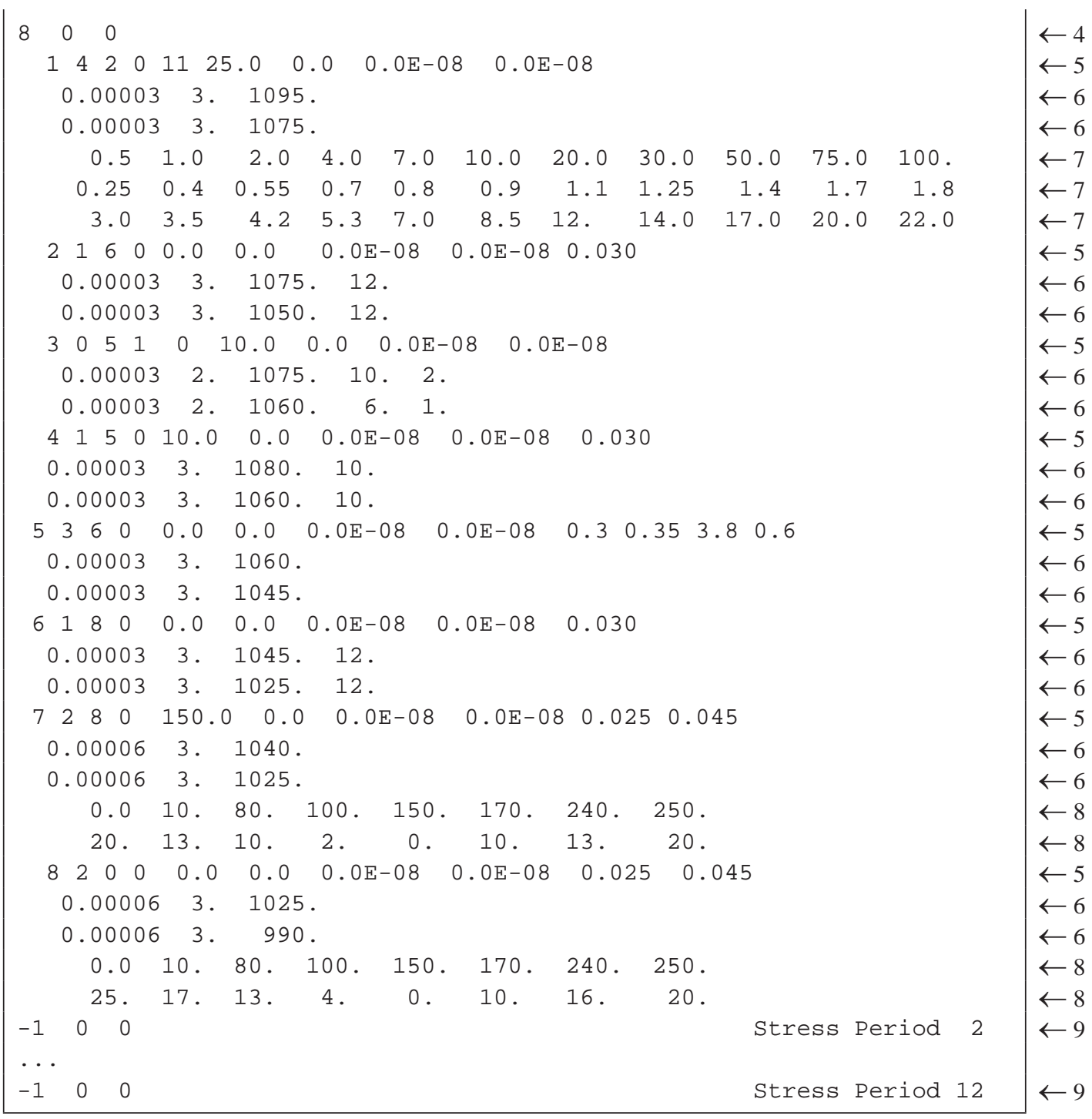

1 Optional text line for comments.

2 Basic stream network description.

3 Stream reach descriptions.

${ }^{4}$ Read and print flags for stress period.

5 General stream segment data.

6 Stream segment data for upstream and downstream ends.

7 Stream segment data when relation of flow to depth and width read from table.

8 Stream segment data for 8-point cross section.

${ }^{9}$ Read and print flags for stress periods $2-12$. 
Following (enclosed in a border) are the contents of the Gage package input file test simulation 2; explanations are noted as comments at the end of each record:

File name: UzFtest1.gag

\begin{tabular}{|llllllll}
\hline 9 & \multicolumn{7}{c|}{ NUMGAGE } \\
1 & 4 & 83 & 4 & Stream Segment \& Reach \#; Output file for Gage 1; Output option \\
2 & 3 & 84 & 1 & Stream Segment \& Reach \#; Output file for Gage 2; Output option \\
3 & 6 & 85 & 1 & Stream Segment \& Reach \#; Output file for Gage 3; Output option \\
4 & 3 & 86 & 1 & Stream Segment \& Reach \#; Output file for Gage 4; Output option \\
5 & 4 & 87 & 4 & Stream Segment \& Reach \#; Output file for Gage 5; Output option \\
6 & 5 & 88 & 1 & Stream Segment \& Reach \#; Output file for Gage 6; Output option \\
7 & 3 & 89 & 4 & Stream Segment \& Reach \#; Output file for Gage 7; Output option \\
8 & 6 & 90 & 4 & Stream Segment \& Reach \#; Output file for Gage 8; Output option \\
3 & 1 & 91 & 5 & Stream Segment \& Reach \#; Output file for Gage 9; Output option \\
\hline
\end{tabular}

Following (enclosed in a border) are the contents of the Output-Control Option input file for test simulation 2.

File name: UzFtest $2.0 \mathrm{c}$

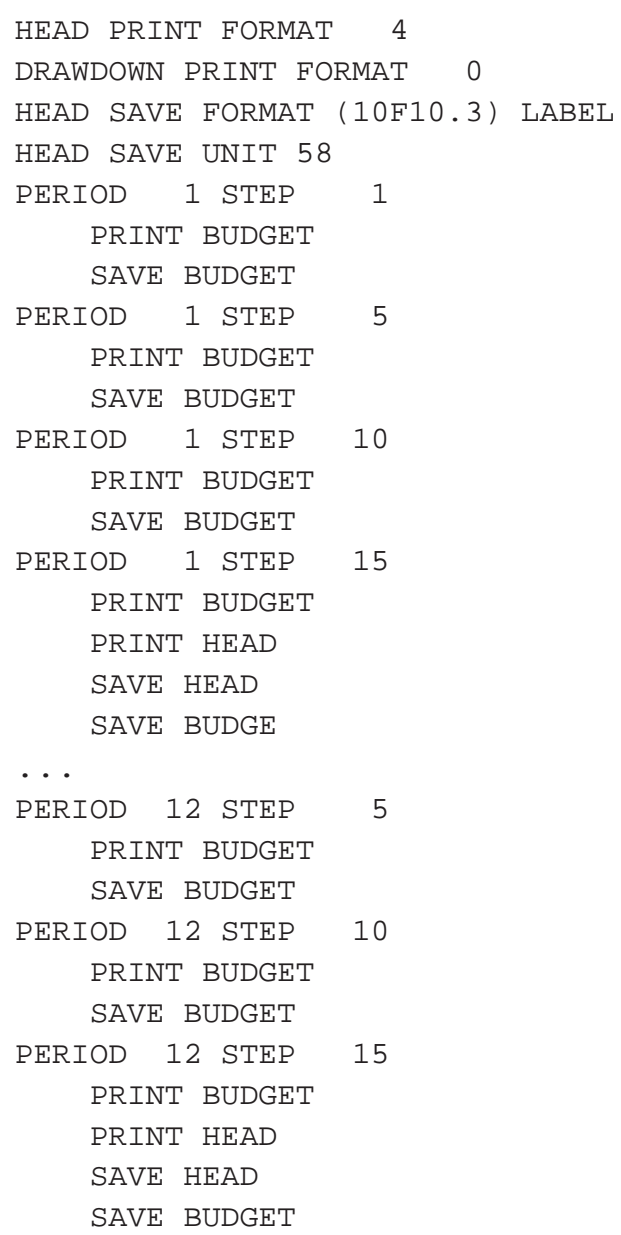




\section{Listing of Selected Output Files for Test Simulation 2}

Following are the contents of the main MODFLOW listing file for test simulation 1:

File name: UZFtest2. Ist

MODFLOW-2005

U.S. GEOLOGICAL SURVEY MODULAR FINITE-DIFFERENCE GROUND-WATER FLOW MODEL VERSION $1.0012 / 15 / 2005$

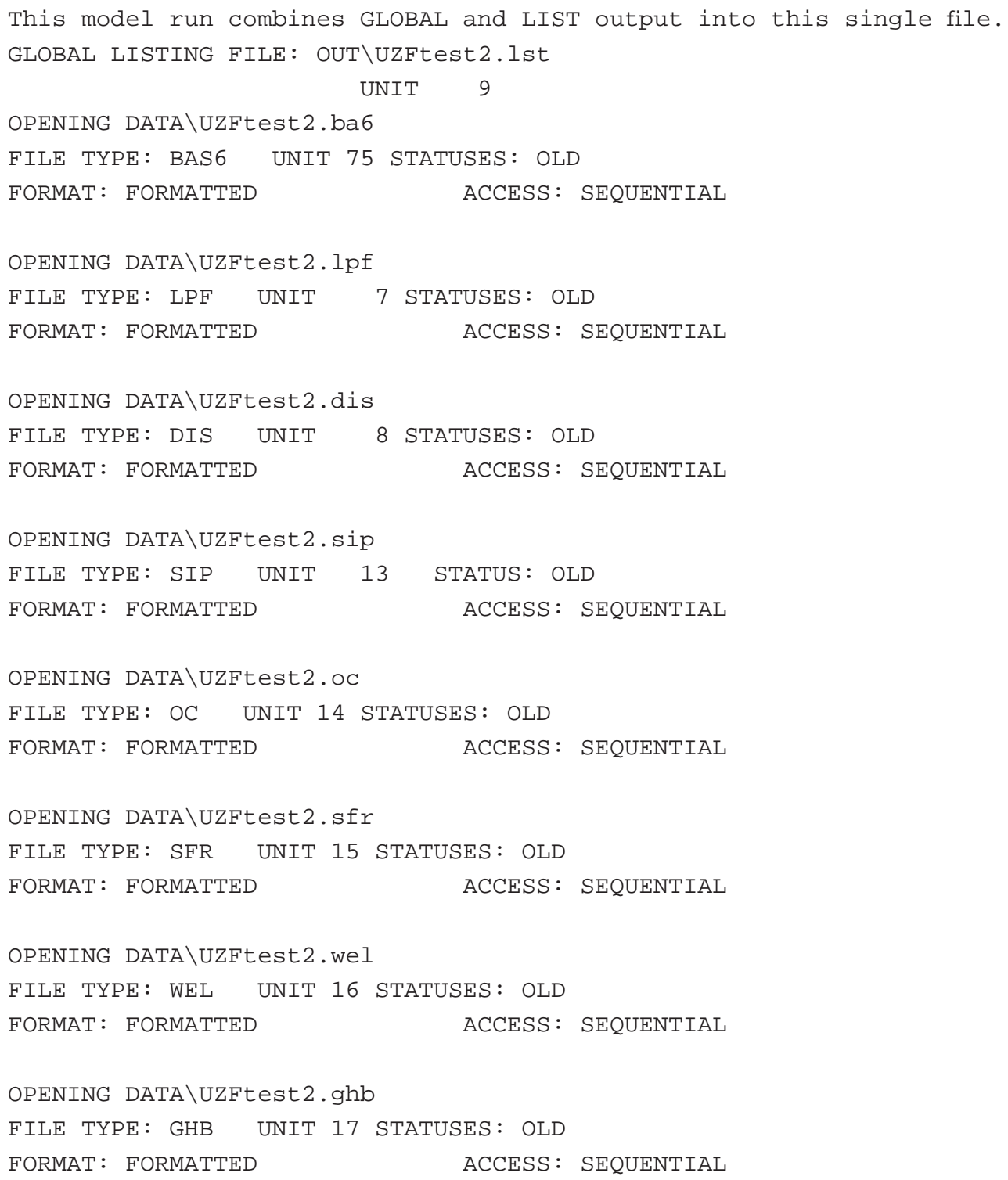


OPENING OUT \UZFtest2hd.out

FILE TYPE: DATA UNIT 58 STATUS: UNKNOWN

FORMAT:FORMATTED ACCESS :SEQUENTIAL

OPENING OUT \UZFtest2.uzfot

FILE TYPE:DATA (BINARY) UNIT 61 STATUS:UNKNOWN

FORMAT : BINARY ACCESS : SEQUENTIAL

OPENING OUT\UZFtest2.uzf1

FILE TYPE:DATA UNIT 65

FORMAT : FORMATTED ACCESS : SEQUENTIAL

OPENING OUT\UZFtest2.uzf2

FILE TYPE:DATA UNIT 66 STATUS:UNKNOWN

FORMAT : FORMATTED ACCESS : SEQUENTIAL

OPENING OUT\UZFtest2.uzf3

FILE TYPE:DATA UNIT 67 STATUS:UNKNOWN

FORMAT:FORMATTED ACCESS:SEQUENTIAL

OPENING OUT\UZFtest2.uzf4

FILE TYPE:DATA UNIT 68 STATUS:UNKNOWN

FORMAT :FORMATTED ACCESS : SEQUENTIAL

‥

DISCRETIZATION INPUT DATA READ FROM UNIT 8

\#Test problem 2-- Discretization input

\#Example problem using the UZF1 Package
1 LAYERS
15 ROWS
10 COLUMNS

12 STRESS PERIOD(S) IN SIMULATION

MODEL TIME UNIT IS SECONDS

MODEL LENGTH UNIT IS FEET

Confining bed flag for each layer:

0

DELR $=5000.00$
DELC $=5000.00$

$\cdots$ 
TOP ELEVATION OF LAYER 1

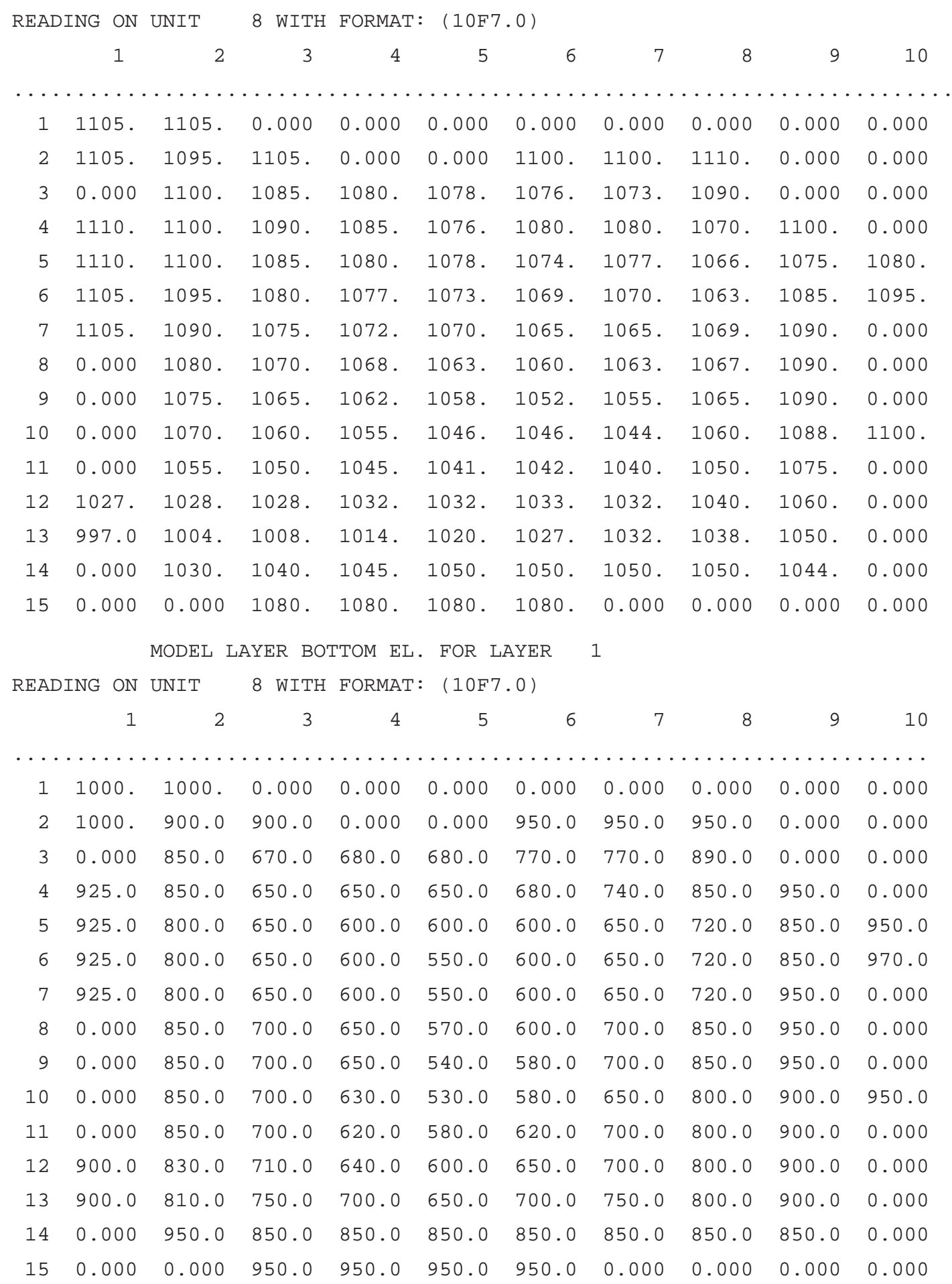




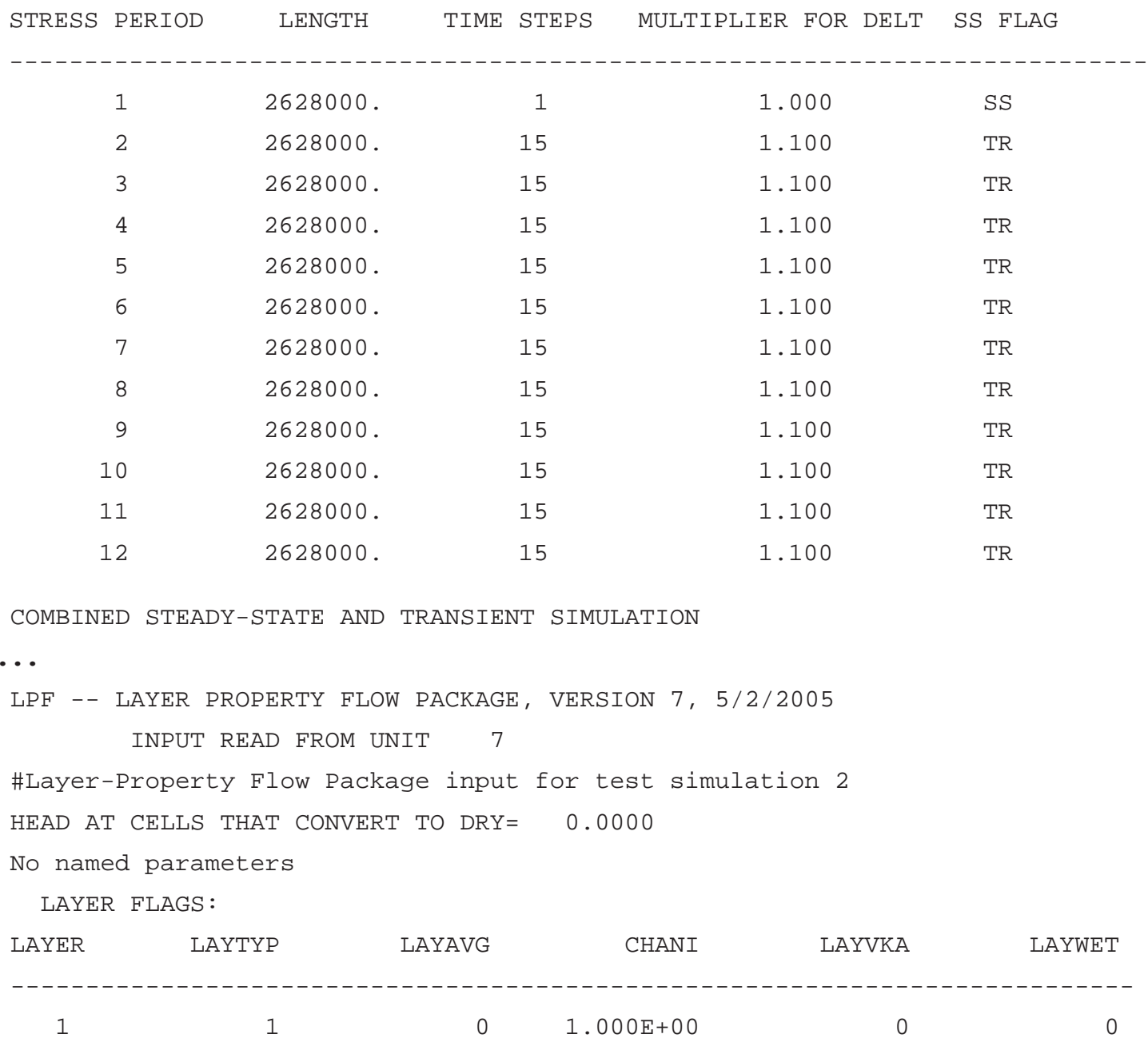

\begin{tabular}{lccccc}
\multicolumn{1}{c}{ INTERPRETATION OF } & LAYER FLAGS: \\
& INTERBLOCK & HORIZONTAL & DATA IN & \\
& LAYER TYPE & TRANSMISSIVITY & ANISOTROPY & ARRAY VKA & WETTABILITY \\
LAYER & (LAYTYP) & (LAYAVG) & (CHANI) & (LAYVKA) & (LAYWET)
\end{tabular}

1 CONVERTIBLE HARMONIC $1.000 \mathrm{E}+00$ VERTICAL K NON-WETTABLE




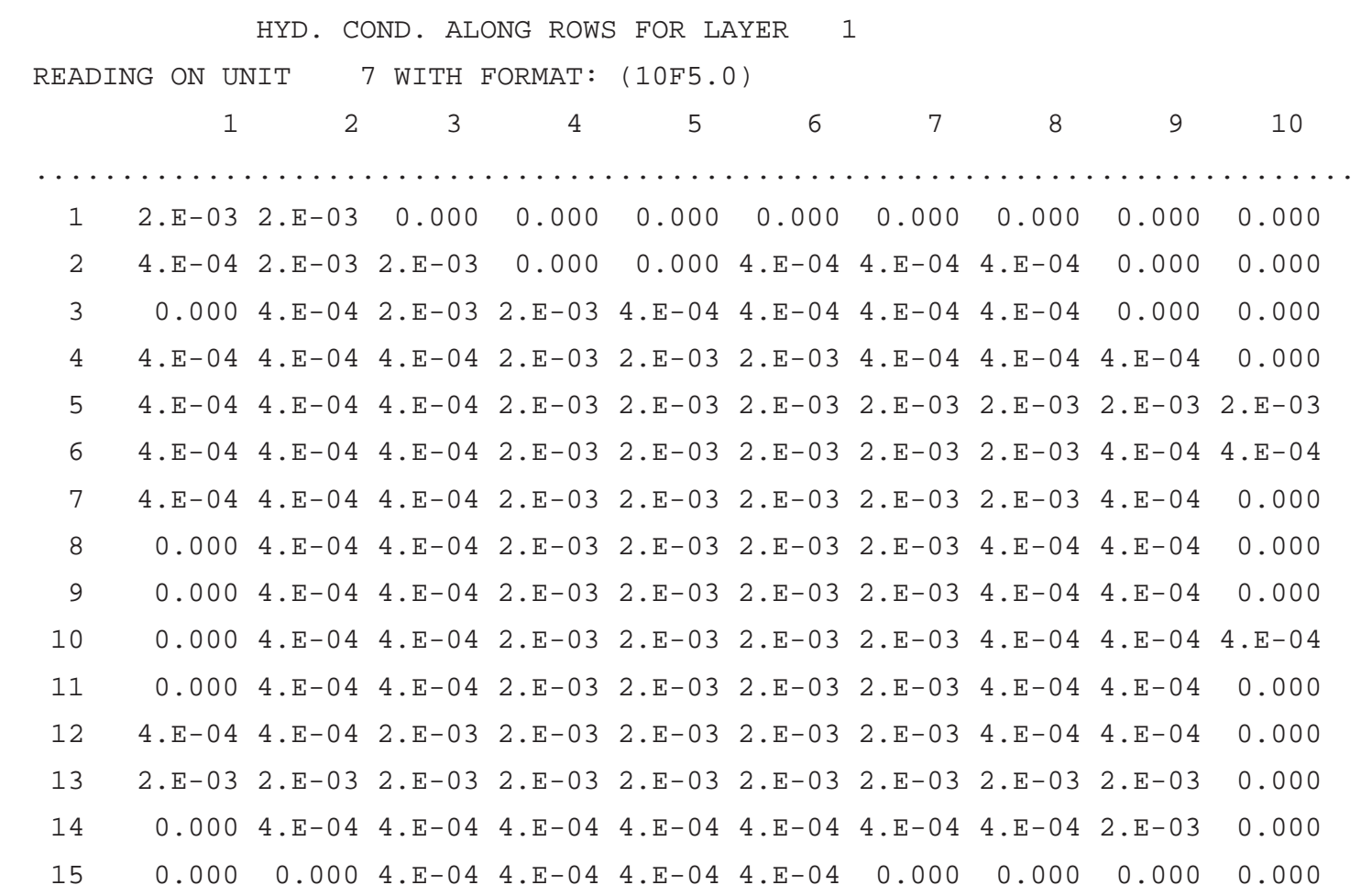

VERTICAL HYD. COND. $=1.000000 \mathrm{E}-06$ FOR LAYER 1

SPECIFIC STORAGE $=1.000000 \mathrm{E}-06$ FOR LAYER 1

\begin{tabular}{|c|c|c|c|c|c|c|c|c|c|c|}
\hline \multirow{2}{*}{\multicolumn{2}{|c|}{ READING ON }} & \multicolumn{5}{|c|}{ SPECIFIC YIELD FOR LAYER } & \multicolumn{4}{|l|}{1} \\
\hline & & UNIT & 7 WITH & FORMAT: & $: \quad(10 \mathrm{~F}$ & $.0)$ & & & & \\
\hline & 1 & 2 & 3 & 4 & 5 & 6 & 7 & 8 & 9 & 10 \\
\hline 1 & 0.200 & 0.200 & 0.000 & 0.000 & 0.000 & 0.000 & 0.000 & 0.000 & 0.000 & 0.000 \\
\hline 2 & 0.100 & 0.200 & 0.200 & 0.000 & 0.000 & 0.100 & 0.100 & 0.100 & 0.000 & 0.000 \\
\hline 3 & 0.000 & 0.100 & 0.200 & 0.200 & 0.100 & 0.100 & 0.100 & 0.100 & 0.000 & 0.000 \\
\hline 4 & 0.100 & 0.100 & 0.100 & 0.200 & 0.200 & 0.200 & 0.100 & 0.100 & 0.100 & 0.000 \\
\hline 5 & 0.100 & 0.100 & 0.100 & 0.200 & 0.200 & 0.200 & 0.200 & 0.200 & 0.200 & 0.200 \\
\hline 6 & 0.100 & 0.100 & 0.100 & 0.200 & 0.200 & 0.200 & 0.200 & 0.200 & 0.100 & 0.100 \\
\hline 7 & 0.100 & 0.100 & 0.100 & 0.200 & 0.200 & 0.200 & 0.200 & 0.200 & 0.100 & 0.000 \\
\hline 8 & 0.000 & 0.100 & 0.100 & 0.200 & 0.200 & 0.200 & 0.200 & 0.100 & 0.100 & 0.000 \\
\hline 9 & 0.000 & 0.100 & 0.100 & 0.200 & 0.200 & 0.200 & 0.200 & 0.100 & 0.100 & 0.000 \\
\hline 10 & 0.000 & 0.100 & 0.100 & 0.200 & 0.200 & 0.200 & 0.200 & 0.100 & 0.100 & 0.100 \\
\hline 11 & 0.000 & 0.100 & 0.100 & 0.200 & 0.200 & 0.200 & 0.200 & 0.100 & 0.100 & 0.000 \\
\hline 12 & 0.100 & 0.100 & 0.200 & 0.200 & 0.200 & 0.200 & 0.200 & 0.100 & 0.100 & 0.000 \\
\hline 13 & 0.200 & 0.200 & 0.200 & 0.200 & 0.200 & 0.200 & 0.200 & 0.200 & 0.200 & 0.000 \\
\hline 14 & 0.000 & 0.100 & 0.100 & 0.100 & 0.100 & 0.100 & 0.100 & 0.100 & 0.200 & 0.000 \\
\hline 15 & 0.000 & 0.000 & 0.100 & 0.100 & 0.100 & 0.100 & 0.000 & 0.000 & 0.000 & 0.000 \\
\hline
\end{tabular}

.. 
UZF1 -- UNSATURATED FLOW PACKAGE, VERSION 1.2, 1/14/2006

INPUT READ FROM UNIT 19

\#UZF Package input for test simulation 2

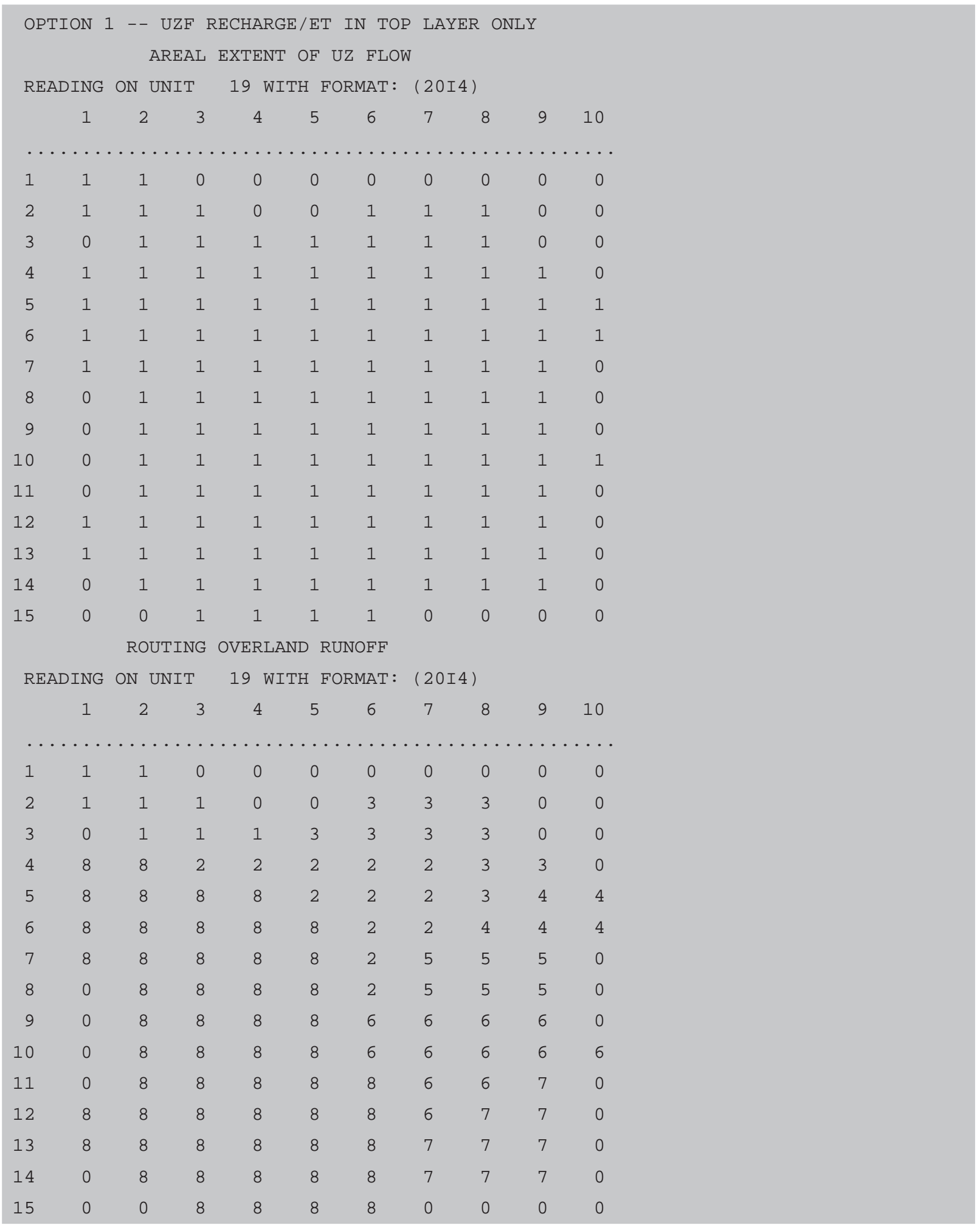




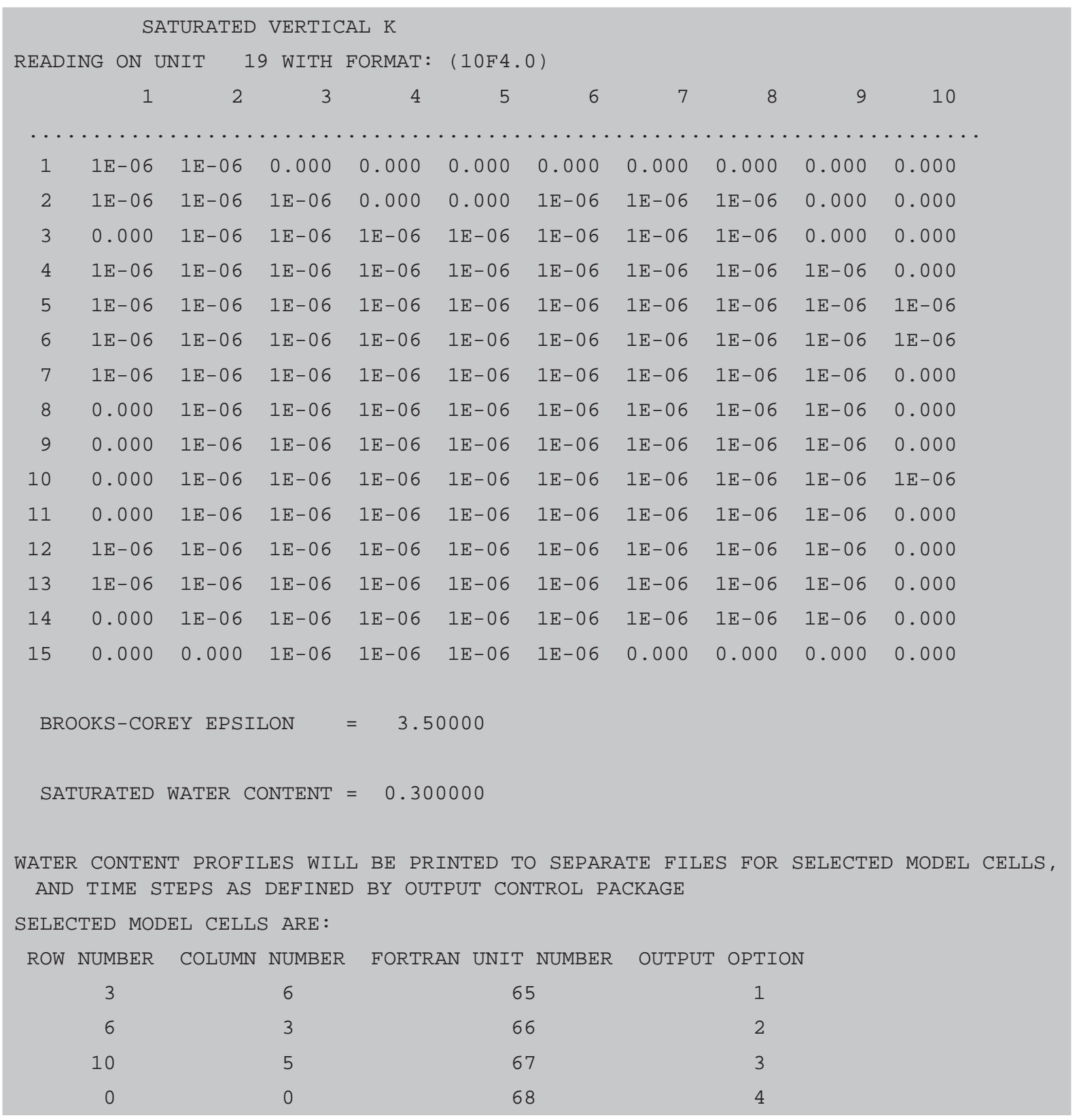

$\cdots$

SOLUTION BY THE STRONGLY IMPLICIT PROCEDURE

MAXIMUM ITERATIONS ALLOWED FOR CLOSURE =

ACCELERATION PARAMETER $=0.80000$

HEAD CHANGE CRITERION FOR CLOSURE $=0.20000 \mathrm{E}-03$

SIP HEAD CHANGE PRINTOUT INTERVAL $=1$

CALCULATE ITERATION PARAMETERS FROM MODEL CALCULATED WSEED

STRESS PERIOD NO. 1 , LENGTH $=2628000$.

$\begin{array}{rr}\text { NUMBER OF TIME STEPS }= & 1 \\ \text { MULTIPLIER FOR DELT }= & 1.000 \\ \text { INITIAL TIME STEP SIZE }= & 2628000 .\end{array}$


AREAL INFILTRATION RATE

READING ON UNIT 19 WITH FORMAT: (10F4.0)

$\begin{array}{llllllllll}1 & 2 & 3 & 4 & 5 & 6 & 7 & 8 & 9 & 10\end{array}$

$\begin{array}{ccccccccccc}1 & 1 \mathrm{E}-09 & 2 \mathrm{E}-09 & 0.000 & 0.000 & 0.000 & 0.000 & 0.000 & 0.000 & 0.000 & 0.000 \\ 2 & 2 \mathrm{E}-09 & 1 \mathrm{E}-09 & 2 \mathrm{E}-09 & 0.000 & 0.000 & 8 \mathrm{E}-09 & 8 \mathrm{E}-09 & 5 \mathrm{E}-09 & 0.000 & 0.000 \\ 3 & 0.000 & 5 \mathrm{E}-09 & 1 \mathrm{E}-09 & 1 \mathrm{E}-09 & 8 \mathrm{E}-09 & 8 \mathrm{E}-09 & 5 \mathrm{E}-09 & 5 \mathrm{E}-09 & 0.000 & 0.000 \\ 4 & 8 \mathrm{E}-09 & 5 \mathrm{E}-09 & 1 \mathrm{E}-09 & 1 \mathrm{E}-09 & 1 \mathrm{E}-09 & 1 \mathrm{E}-09 & 1 \mathrm{E}-09 & 1 \mathrm{E}-09 & 2 \mathrm{E}-09 & 0.000 \\ 5 & 8 \mathrm{E}-09 & 5 \mathrm{E}-09 & 1 \mathrm{E}-09 & 1 \mathrm{E}-09 & 1 \mathrm{E}-09 & 1 \mathrm{E}-09 & 1 \mathrm{E}-09 & 1 \mathrm{E}-09 & 1 \mathrm{E}-09 & 1 \mathrm{E}-09 \\ 6 & 8 \mathrm{E}-09 & 5 \mathrm{E}-09 & 5 \mathrm{E}-09 & 2 \mathrm{E}-09 & 2 \mathrm{E}-09 & 1 \mathrm{E}-09 & 1 \mathrm{E}-09 & 1 \mathrm{E}-09 & 1 \mathrm{E}-09 & 5 \mathrm{E}-09 \\ 7 & 8 \mathrm{E}-09 & 5 \mathrm{E}-09 & 5 \mathrm{E}-09 & 2 \mathrm{E}-09 & 2 \mathrm{E}-09 & 1 \mathrm{E}-09 & 1 \mathrm{E}-09 & 1 \mathrm{E}-09 & 2 \mathrm{E}-09 & 0.000 \\ 8 & 0.000 & 5 \mathrm{E}-09 & 5 \mathrm{E}-09 & 2 \mathrm{E}-09 & 2 \mathrm{E}-09 & 1 \mathrm{E}-09 & 1 \mathrm{E}-09 & 2 \mathrm{E}-09 & 5 \mathrm{E}-09 & 0.000 \\ 9 & 0.000 & 5 \mathrm{E}-09 & 5 \mathrm{E}-09 & 2 \mathrm{E}-09 & 2 \mathrm{E}-09 & 1 \mathrm{E}-09 & 1 \mathrm{E}-09 & 2 \mathrm{E}-09 & 5 \mathrm{E}-09 & 0.000 \\ 10 & 0.000 & 5 \mathrm{E}-09 & 5 \mathrm{E}-09 & 2 \mathrm{E}-09 & 2 \mathrm{E}-09 & 1 \mathrm{E}-09 & 1 \mathrm{E}-09 & 2 \mathrm{E}-09 & 5 \mathrm{E}-09 & 8 \mathrm{E}-09 \\ 11 & 0.000 & 1 \mathrm{E}-09 & 1 \mathrm{E}-09 & 1 \mathrm{E}-09 & 1 \mathrm{E}-09 & 1 \mathrm{E}-09 & 1 \mathrm{E}-09 & 2 \mathrm{E}-09 & 5 \mathrm{E}-09 & 0.000 \\ 12 & 1 \mathrm{E}-09 & 1 \mathrm{E}-09 & 1 \mathrm{E}-09 & 1 \mathrm{E}-09 & 1 \mathrm{E}-09 & 1 \mathrm{E}-09 & 1 \mathrm{E}-09 & 1 \mathrm{E}-09 & 2 \mathrm{E}-09 & 0.000 \\ 13 & 1 \mathrm{E}-09 & 1 \mathrm{E}-09 & 2 \mathrm{E}-09 & 2 \mathrm{E}-09 & 2 \mathrm{E}-09 & 2 \mathrm{E}-09 & 2 \mathrm{E}-09 & 1 \mathrm{E}-09 & 1 \mathrm{E}-09 & 0.000 \\ 14 & 0.000 & 2 \mathrm{E}-09 & 5 \mathrm{E}-09 & 5 \mathrm{E}-09 & 5 \mathrm{E}-09 & 5 \mathrm{E}-09 & 5 \mathrm{E}-09 & 2 \mathrm{E}-09 & 1 \mathrm{E}-09 & 0.000 \\ 15 & 0.000 & 0.000 & 8 \mathrm{E}-09 & 8 \mathrm{E}-09 & 8 \mathrm{E}-09 & 8 \mathrm{E}-09 & 0.000 & 0.000 & 0.000 & 0.000\end{array}$

ET DEMAND RATE $=5.000000 \mathrm{E}-08$

ET EXTINCTION DEPTH $=15.0000$

EXTINCTION WATER CONTENT

READING ON UNIT 19 WITH FORMAT: (10F4.0)

$\begin{array}{llllllllll}1 & 2 & 3 & 4 & 5 & 6 & 7 & 8 & 9 & 10\end{array}$

$\begin{array}{ccccccccccc}1 & 0.10 & 0.10 & 0.00 & 0.00 & 0.00 & 0.00 & 0.00 & 0.00 & 0.00 & 0.00 \\ 2 & 0.20 & 0.10 & 0.10 & 0.00 & 0.00 & 0.20 & 0.20 & 0.20 & 0.00 & 0.00 \\ 3 & 0.00 & 0.20 & 0.10 & 0.10 & 0.20 & 0.20 & 0.20 & 0.20 & 0.00 & 0.00 \\ 4 & 0.20 & 0.20 & 0.20 & 0.10 & 0.10 & 0.10 & 0.20 & 0.20 & 0.20 & 0.10 \\ 5 & 0.20 & 0.20 & 0.20 & 0.10 & 0.10 & 0.10 & 0.10 & 0.10 & 0.10 & 0.10 \\ 6 & 0.20 & 0.20 & 0.20 & 0.10 & 0.10 & 0.10 & 0.10 & 0.10 & 0.20 & 0.20 \\ 7 & 0.20 & 0.20 & 0.20 & 0.10 & 0.10 & 0.10 & 0.10 & 0.10 & 0.20 & 0.00 \\ 8 & 0.00 & 0.20 & 0.20 & 0.10 & 0.10 & 0.10 & 0.10 & 0.20 & 0.20 & 0.00 \\ 9 & 0.00 & 0.20 & 0.20 & 0.10 & 0.10 & 0.10 & 0.10 & 0.20 & 0.20 & 0.00 \\ 10 & 0.00 & 0.20 & 0.20 & 0.10 & 0.10 & 0.10 & 0.10 & 0.20 & 0.20 & 0.20 \\ 11 & 0.00 & 0.20 & 0.20 & 0.10 & 0.10 & 0.10 & 0.10 & 0.20 & 0.20 & 0.00 \\ 12 & 0.20 & 0.20 & 0.10 & 0.10 & 0.10 & 0.10 & 0.10 & 0.20 & 0.20 & 0.00 \\ 13 & 0.10 & 0.10 & 0.10 & 0.10 & 0.10 & 0.10 & 0.10 & 0.10 & 0.10 & 0.00 \\ 14 & 0.00 & 0.20 & 0.20 & 0.20 & 0.20 & 0.20 & 0.20 & 0.20 & 0.10 & 0.00 \\ 15 & 0.00 & 0.00 & 0.20 & 0.20 & 0.20 & 0.20 & 0.00 & 0.00 & 0.00 & 0.00\end{array}$




\section{Documentation of the Unsaturated-Zone Flow Package}

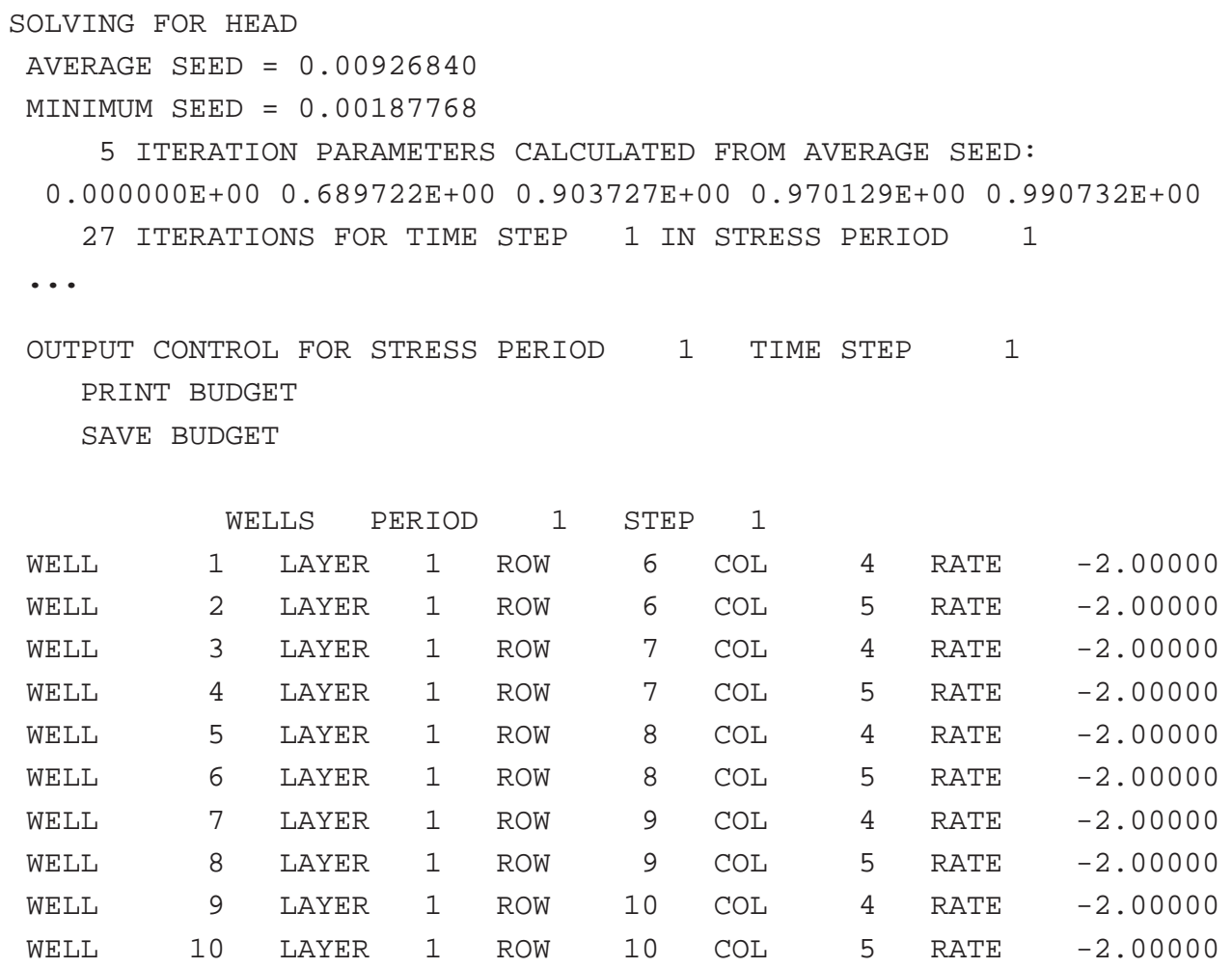

\begin{tabular}{ccccccccccr} 
HEAD DEP & BOUNDS & PERIOD & \multicolumn{1}{c}{ STEP } & 1 & & & & \\
BOUNDARY & 1 & LAYER & 1 & ROW & 13 & COL & 1 & RATE & -0.262024 \\
BOUNDARY & 2 & LAYER & 1 & ROW & 14 & COL & 9 & RATE & 0.209432
\end{tabular}

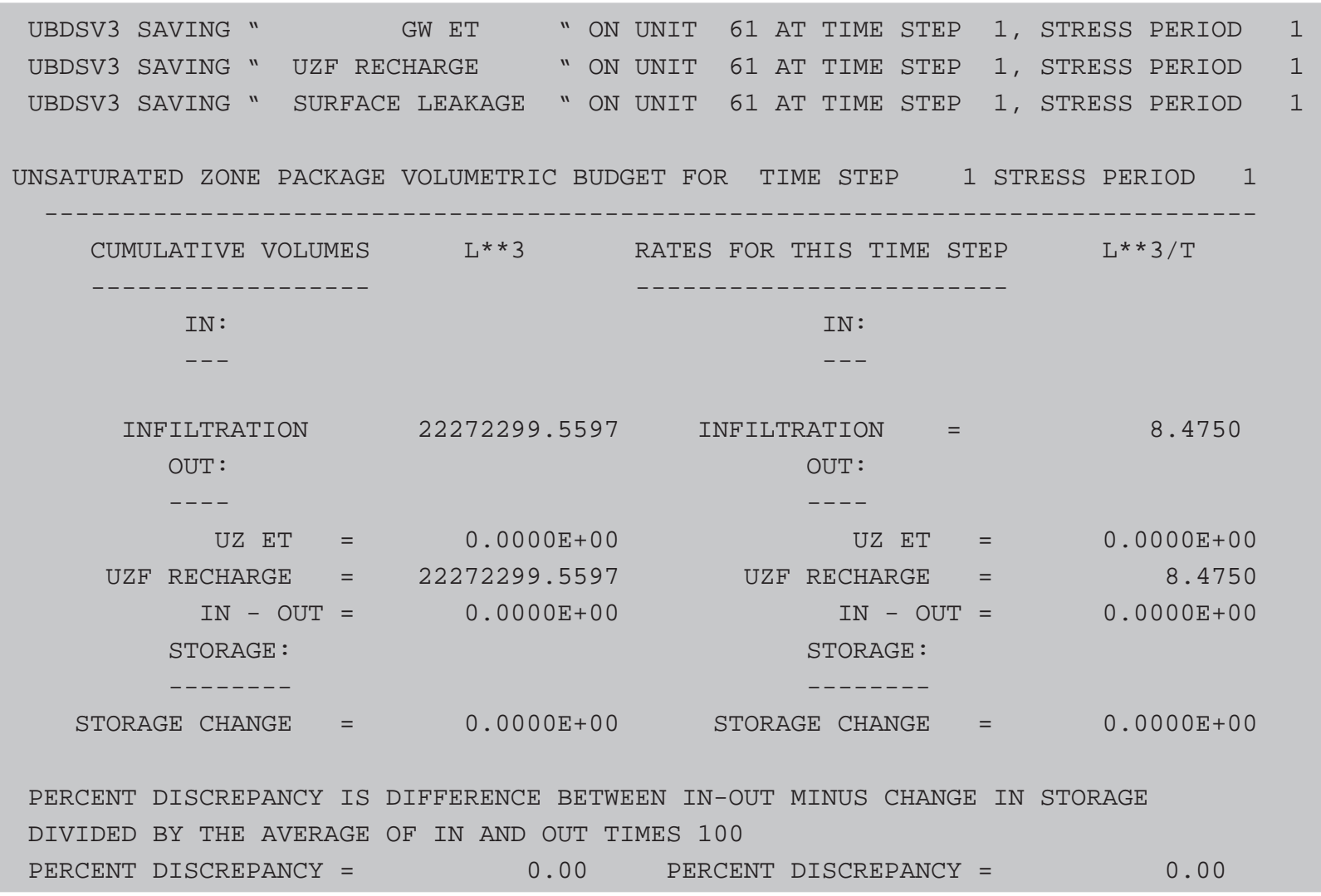


..

VOLUMETRIC BUDGET FOR ENTIRE MODEL AT END OF TIME STEP 1 IN STRESS PERIOD 1

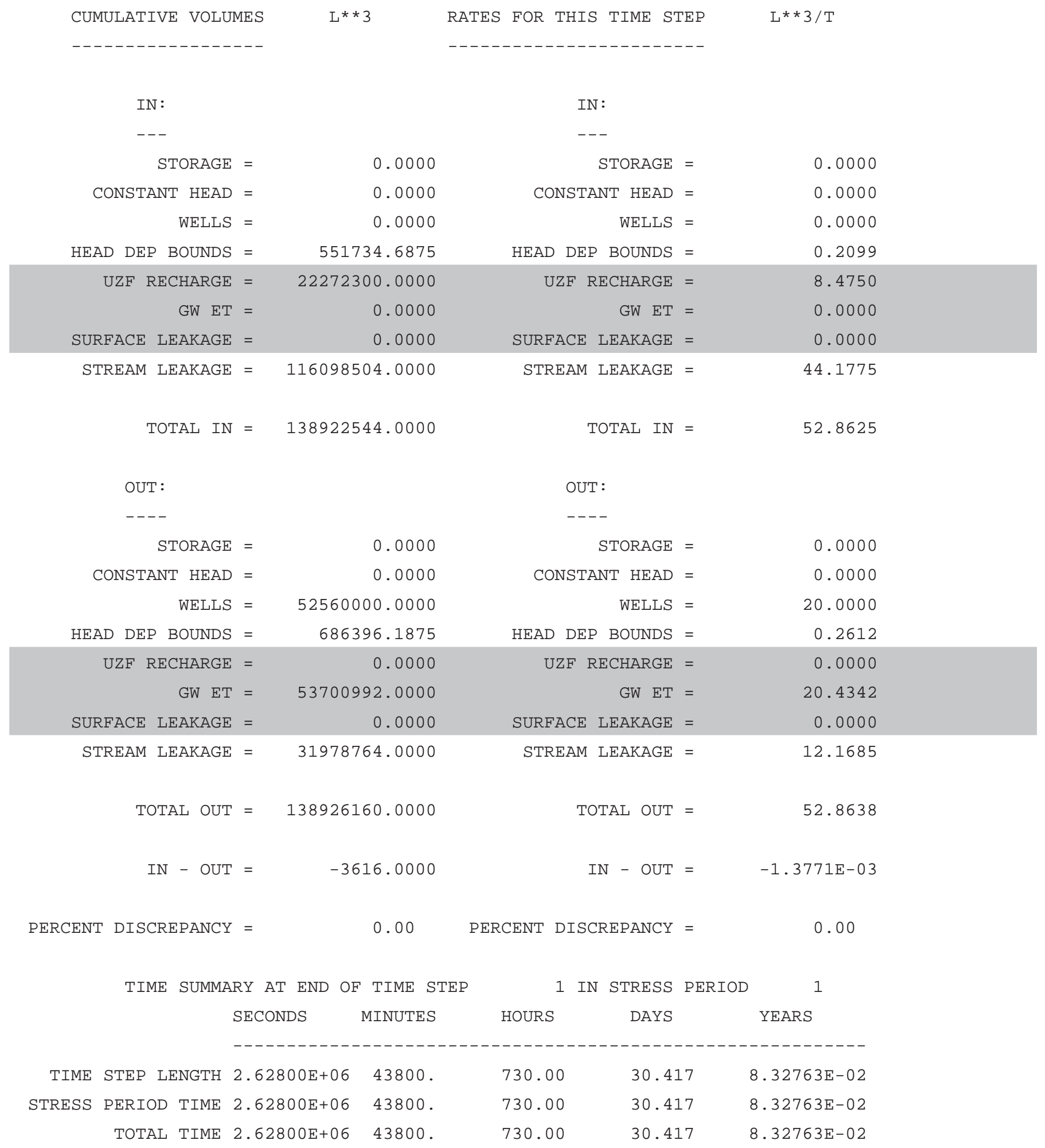




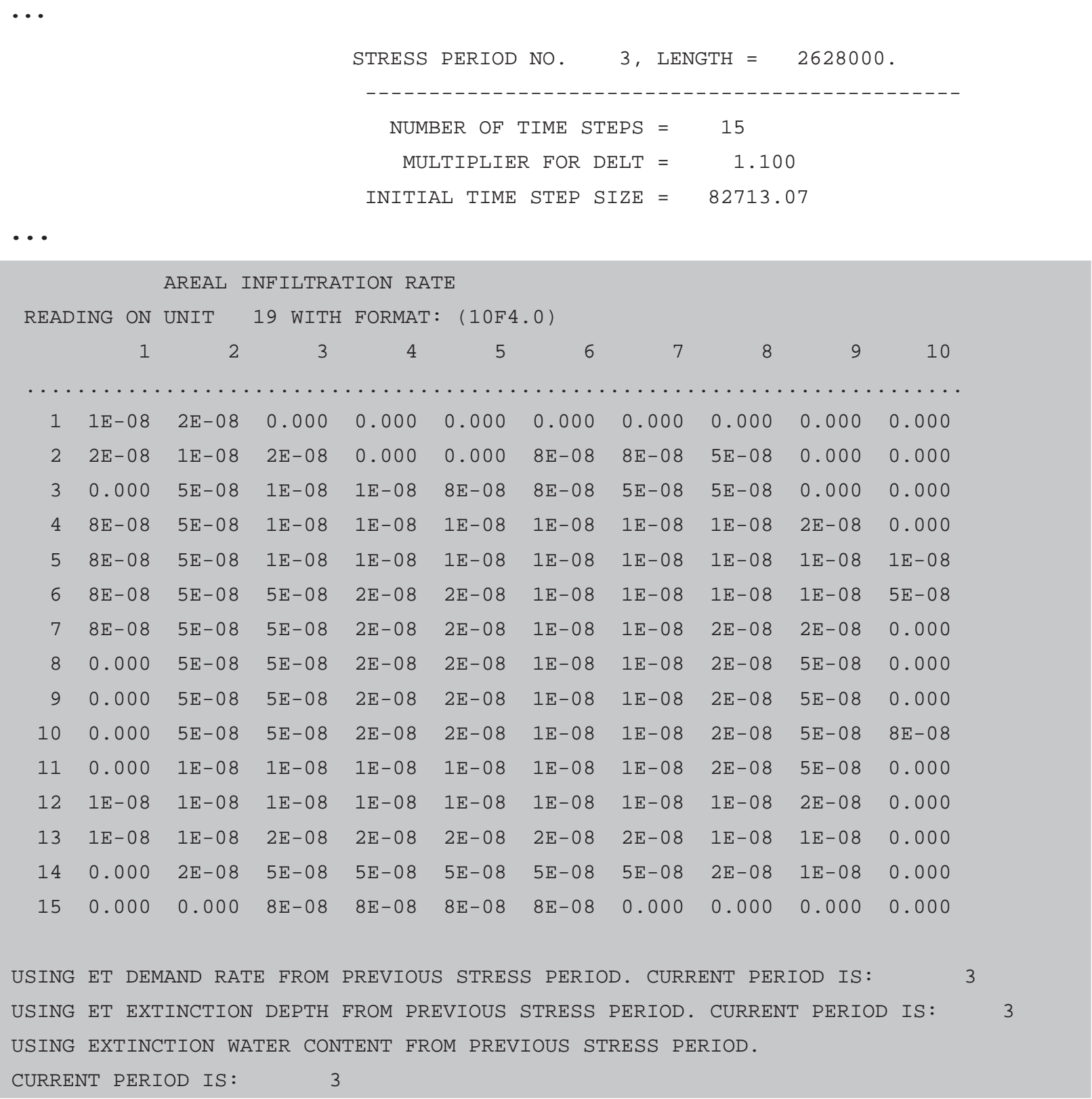




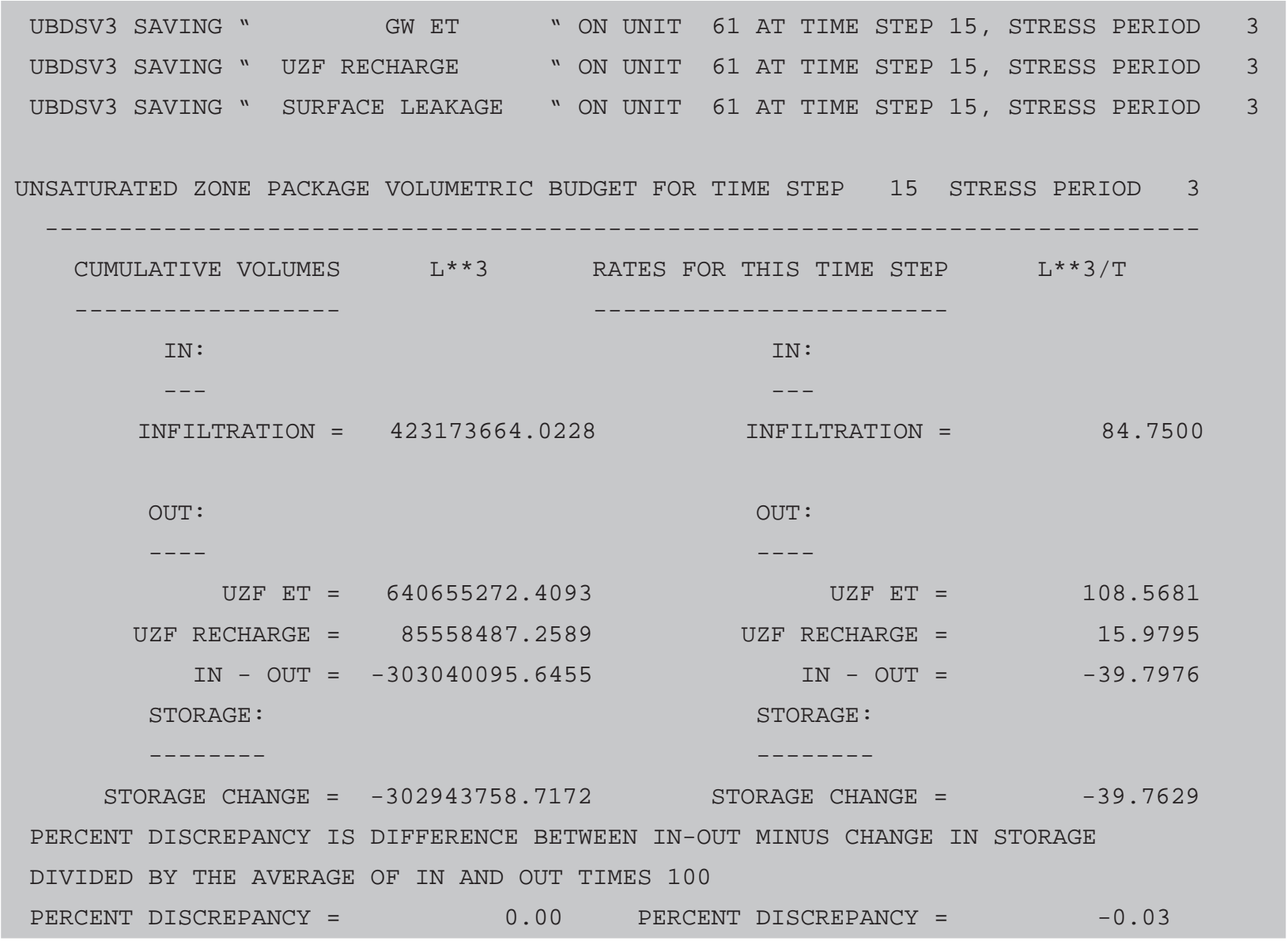


VOLUMETRIC BUDGET FOR ENTIRE MODEL AT END OF TIME STEP 15 IN STRESS PERIOD 3

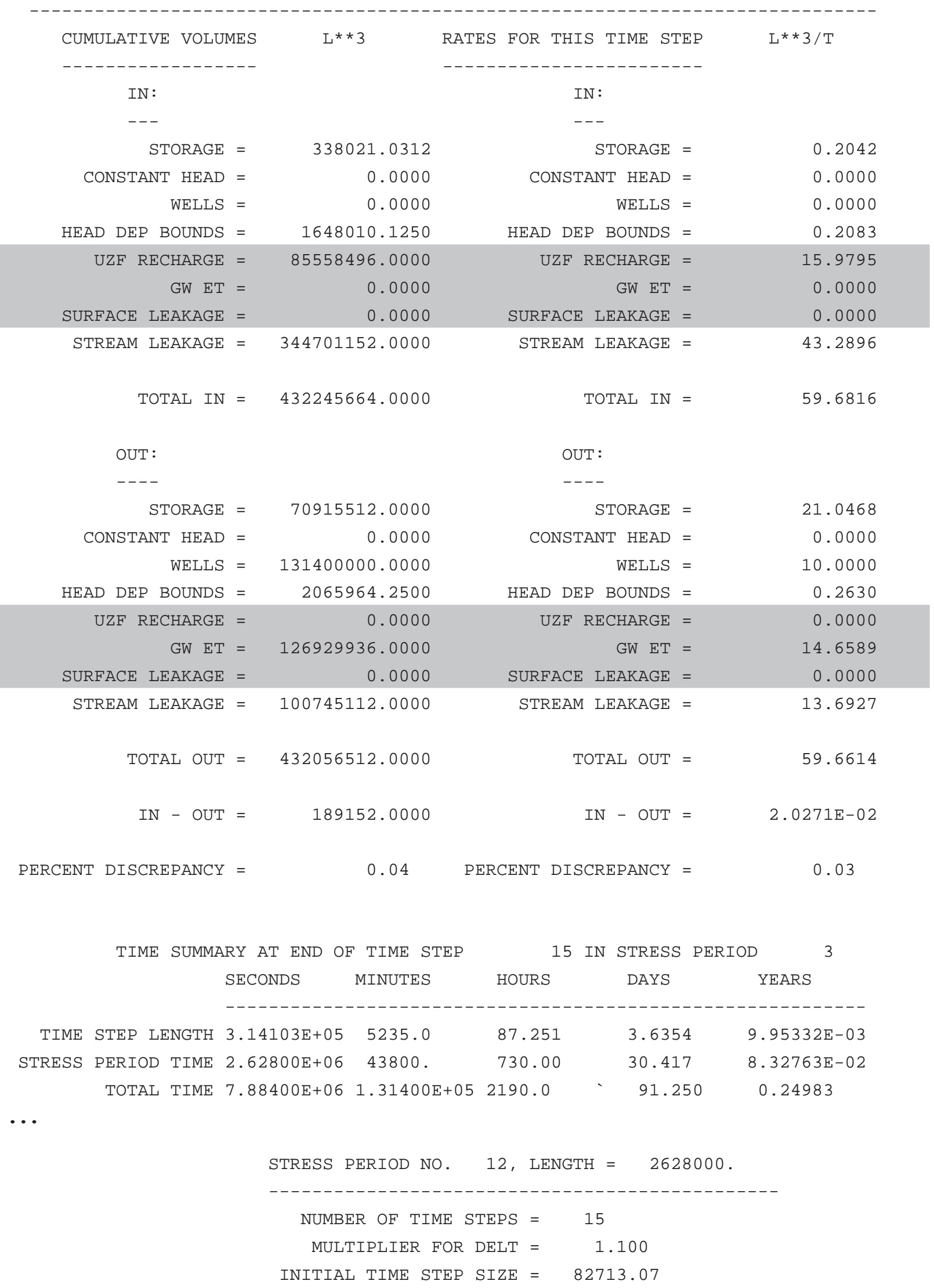


AREAL INFILTRATION RATE

READING ON UNIT 19 WITH FORMAT: (10F4.0)

$\begin{array}{llllllllll}1 & 2 & 3 & 4 & 5 & 6 & 7 & 8 & 9 & 10\end{array}$

$\begin{array}{cccccccccccc}1 & 1 \mathrm{E}-09 & 2 \mathrm{E}-09 & 0.000 & 0.000 & 0.000 & 0.000 & 0.000 & 0.000 & 0.000 & 0.000 \\ 2 & 2 \mathrm{E}-09 & 1 \mathrm{E}-09 & 2 \mathrm{E}-09 & 0.000 & 0.000 & 8 \mathrm{E}-09 & 8 \mathrm{E}-09 & 5 \mathrm{E}-09 & 0.000 & 0.000 \\ 3 & 0.000 & 5 \mathrm{E}-09 & 1 \mathrm{E}-09 & 1 \mathrm{E}-09 & 8 \mathrm{E}-09 & 8 \mathrm{E}-09 & 5 \mathrm{E}-09 & 5 \mathrm{E}-09 & 0.000 & 0.000 \\ 4 & 8 \mathrm{E}-09 & 5 \mathrm{E}-09 & 1 \mathrm{E}-09 & 1 \mathrm{E}-09 & 1 \mathrm{E}-09 & 1 \mathrm{E}-09 & 1 \mathrm{E}-09 & 1 \mathrm{E}-09 & 2 \mathrm{E}-09 & 0.000 \\ 5 & 8 \mathrm{E}-09 & 5 \mathrm{E}-09 & 1 \mathrm{E}-09 & 1 \mathrm{E}-09 & 1 \mathrm{E}-09 & 1 \mathrm{E}-09 & 1 \mathrm{E}-09 & 1 \mathrm{E}-09 & 1 \mathrm{E}-09 & 1 \mathrm{E}-09 \\ 6 & 8 \mathrm{E}-09 & 5 \mathrm{E}-09 & 5 \mathrm{E}-09 & 2 \mathrm{E}-09 & 2 \mathrm{E}-09 & 1 \mathrm{E}-09 & 1 \mathrm{E}-09 & 1 \mathrm{E}-09 & 1 \mathrm{E}-09 & 5 \mathrm{E}-09 \\ 7 & 8 \mathrm{E}-09 & 5 \mathrm{E}-09 & 5 \mathrm{E}-09 & 2 \mathrm{E}-09 & 2 \mathrm{E}-09 & 1 \mathrm{E}-09 & 1 \mathrm{E}-09 & 2 \mathrm{E}-09 & 2 \mathrm{E}-09 & 0.000 \\ 8 & 0.000 & 5 \mathrm{E}-09 & 5 \mathrm{E}-09 & 2 \mathrm{E}-09 & 2 \mathrm{E}-09 & 1 \mathrm{E}-09 & 1 \mathrm{E}-09 & 2 \mathrm{E}-09 & 5 \mathrm{E}-09 & 0.000 \\ 9 & 0.000 & 5 \mathrm{E}-09 & 5 \mathrm{E}-09 & 2 \mathrm{E}-09 & 2 \mathrm{E}-09 & 1 \mathrm{E}-09 & 1 \mathrm{E}-09 & 2 \mathrm{E}-09 & 5 \mathrm{E}-09 & 0.000 \\ 10 & 0.000 & 5 \mathrm{E}-09 & 5 \mathrm{E}-09 & 2 \mathrm{E}-09 & 2 \mathrm{E}-09 & 1 \mathrm{E}-09 & 1 \mathrm{E}-09 & 2 \mathrm{E}-09 & 5 \mathrm{E}-09 & 8 \mathrm{E}-09 \\ 11 & 0.000 & 1 \mathrm{E}-09 & 1 \mathrm{E}-09 & 1 \mathrm{E}-09 & 1 \mathrm{E}-09 & 1 \mathrm{E}-09 & 1 \mathrm{E}-09 & 2 \mathrm{E}-09 & 5 \mathrm{E}-09 & 0.000 \\ 12 & 1 \mathrm{E}-09 & 1 \mathrm{E}-09 & 1 \mathrm{E}-09 & 1 \mathrm{E}-09 & 1 \mathrm{E}-09 & 1 \mathrm{E}-09 & 1 \mathrm{E}-09 & 1 \mathrm{E}-09 & 2 \mathrm{E}-09 & 0.000 \\ 13 & 1 \mathrm{E}-09 & 1 \mathrm{E}-09 & 2 \mathrm{E}-09 & 2 \mathrm{E}-09 & 2 \mathrm{E}-09 & 2 \mathrm{E}-09 & 2 \mathrm{E}-09 & 1 \mathrm{E}-09 & 1 \mathrm{E}-09 & 0.000 \\ 14 & 0.000 & 2 \mathrm{E}-09 & 5 \mathrm{E}-09 & 5 \mathrm{E}-09 & 5 \mathrm{E}-09 & 5 \mathrm{E}-09 & 5 \mathrm{E}-09 & 2 \mathrm{E}-09 & 1 \mathrm{E}-09 & 0.000 \\ 15 & 0.000 & 0.000 & 8 \mathrm{E}-09 & 8 \mathrm{E}-09 & 8 \mathrm{E}-09 & 8 \mathrm{E}-09 & 0.000 & 0.000 & 0.000 & 0.000\end{array}$

USING ET DEMAND RATE FROM PREVIOUS STRESS PERIOD. CURRENT PERIOD IS: 12

USING ET EXTINCTION DEPTH FROM PREVIOUS STRESS PERIOD. CURRENT PERIOD IS: 12

USING EXTINCTION WATER CONTENT FROM PREVIOUS STRESS PERIOD. CURRENT PERIOD IS: 12

SOLVING FOR HEAD

7 ITERATIONS FOR TIME STEP 1 IN STRESS PERIOD 12 $\cdots$

OUTPUT CONTROL FOR STRESS PERIOD 12 TIME STEP 15

PRINT BUDGET

PRINT HEAD FOR ALL LAYERS

SAVE HEAD FOR ALL LAYERS

SAVE BUDGET 


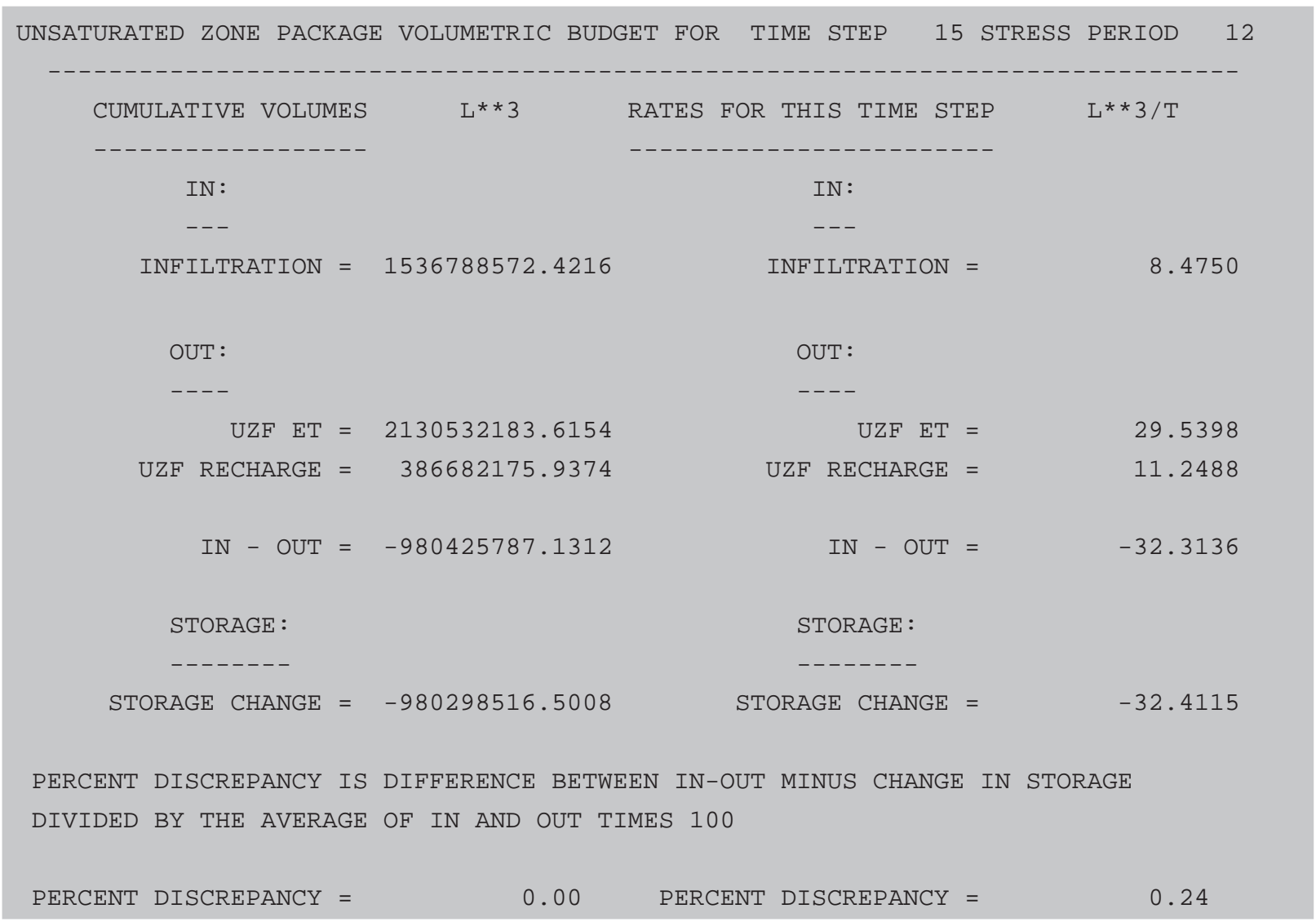

...

HEAD IN LAYER 1 AT END OF TIME STEP 15 IN STRESS PERIOD 12

\begin{tabular}{|c|c|c|c|c|c|c|c|c|c|c|}
\hline & 1 & 2 & 3 & 4 & 5 & 6 & 7 & 8 & 9 & 10 \\
\hline 1 & 1092.37 & 1088.61 & 6999.00 & 6999.00 & 6999.00 & 6999.00 & 6999.00 & 6999.00 & 6999.00 & 6999.00 \\
\hline 2 & 1089.01 & 1085.68 & 1079.29 & 6999.00 & 6999.00 & 1073.62 & 1072.54 & 1070.97 & 6999.00 & 6999.00 \\
\hline 3 & 6999.00 & 1077.38 & 1074.52 & 1070.40 & 1070.89 & 1069.73 & 1068.19 & 1067.88 & 6999.00 & 6999.00 \\
\hline 4 & 1069.50 & 1068.75 & 1067.10 & 1063.67 & 1062.51 & 1061.22 & 1061.78 & 1064.46 & 1063.91 & 6999.00 \\
\hline 5 & 1065.39 & 1061.87 & 1059.39 & 1057.54 & 1057.25 & 1057.77 & 1057.60 & 1059.59 & 1063.01 & 1065.39 \\
\hline 6 & 1060.65 & 1056.02 & 1053.11 & 1051.72 & 1052.00 & 1053.31 & 1054.52 & 1056.79 & 1059.55 & 1063.65 \\
\hline 7 & 1056.94 & 1050.38 & 1047.40 & 1046.23 & 1046.83 & 1048.45 & 1050.78 & 1053.10 & 1054.36 & 6999.00 \\
\hline 8 & 6999.00 & 1042.92 & 1041.40 & 1040.73 & 1041.58 & 1043.41 & 1045.19 & 1047.53 & 1049.31 & 6999.00 \\
\hline 9 & 6999.00 & 1035.92 & 1035.34 & 1035.29 & 1036.46 & 1038.47 & 1039.35 & 1041.08 & 1043.88 & 6999.00 \\
\hline 10 & 6999.00 & 1028.78 & 1029.18 & 1030.18 & 1031.62 & 1033.35 & 1034.61 & 1036.48 & 1040.18 & 1045.29 \\
\hline 11 & 6999.00 & 1019.85 & 1021.63 & 1025.14 & 1027.16 & 1029.21 & 1030.68 & 1032.95 & 1036.39 & 6999.00 \\
\hline 12 & 1001.20 & 1008.88 & 1014.17 & 1019.07 & 1022.71 & 1025.93 & 1028.31 & 1031.01 & 1034.88 & 6999.00 \\
\hline 13 & 994.91 & 1000.19 & 1006.90 & 1013.08 & 1018.90 & 1024.47 & 1029.24 & 1034.27 & 1036.38 & 6999.00 \\
\hline 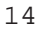 & 6999.00 & 1005.79 & 1011.36 & 1016.09 & 1021.14 & 1025.87 & 1030.11 & 1035.21 & 1039.48 & 6999.00 \\
\hline 5 & 6999.00 & 6999.00 & 1018.95 & 1022.40 & 1026.57 & 1029.77 & 6999.00 & 6999.00 & 6999.00 & 6999.00 \\
\hline
\end{tabular}

HEAD WILL BE SAVED ON UNIT 58 AT END OF TIME STEP 15, STRESS PERIOD 12 


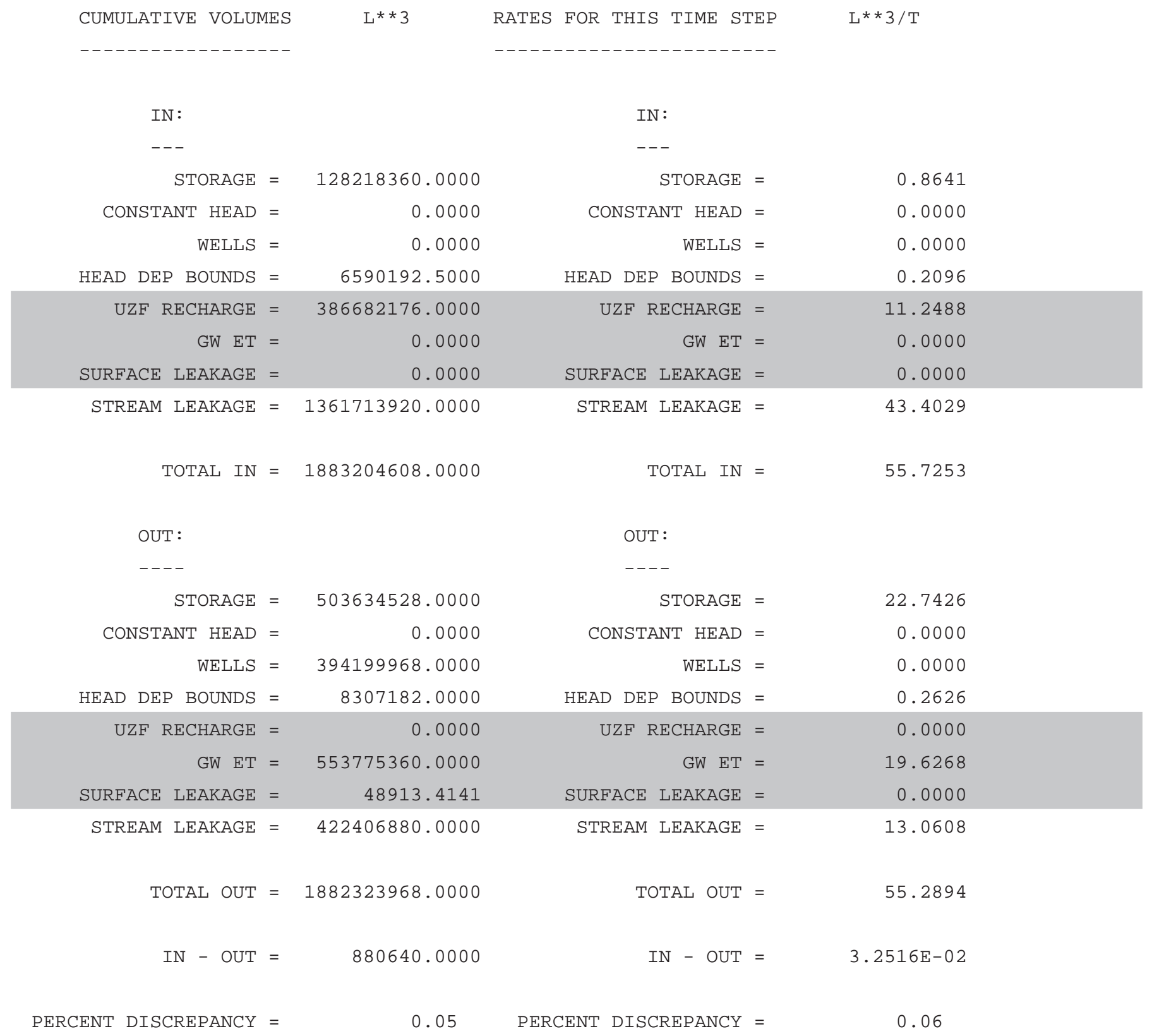

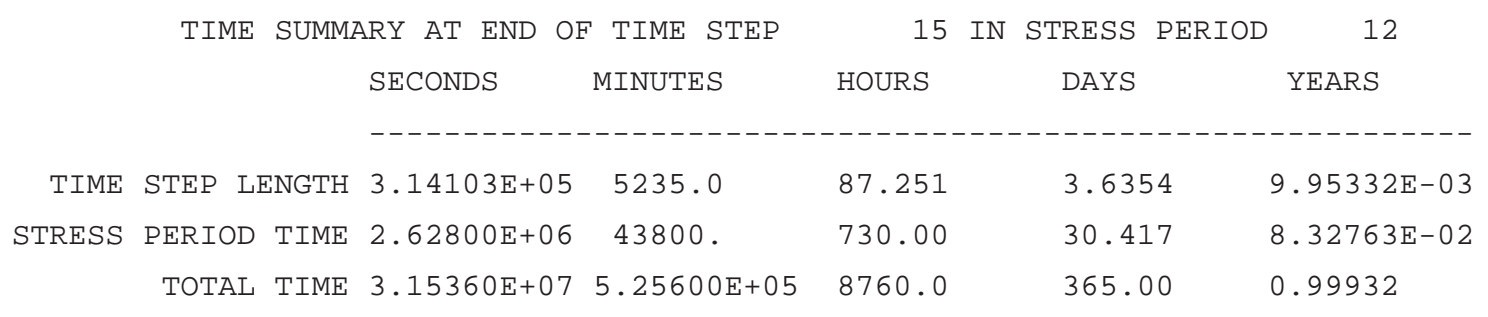


Following are the abridged contents of the UZFtest2.uzf1 output file for test simulation 2.

LOCATION OF SPECIFIED CELL FOR PRINTING VOLUMES IN UNSATURATED ZONE:

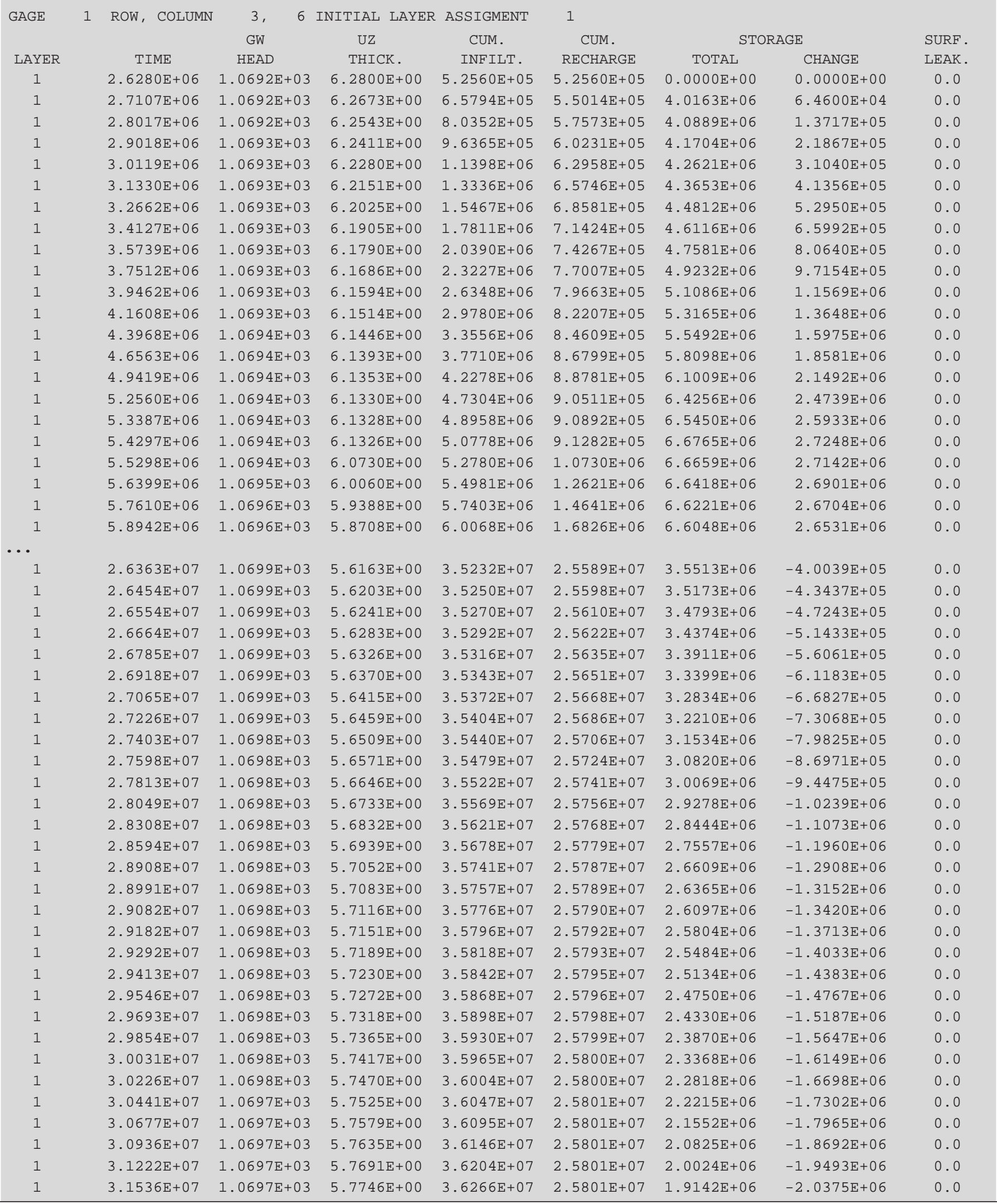




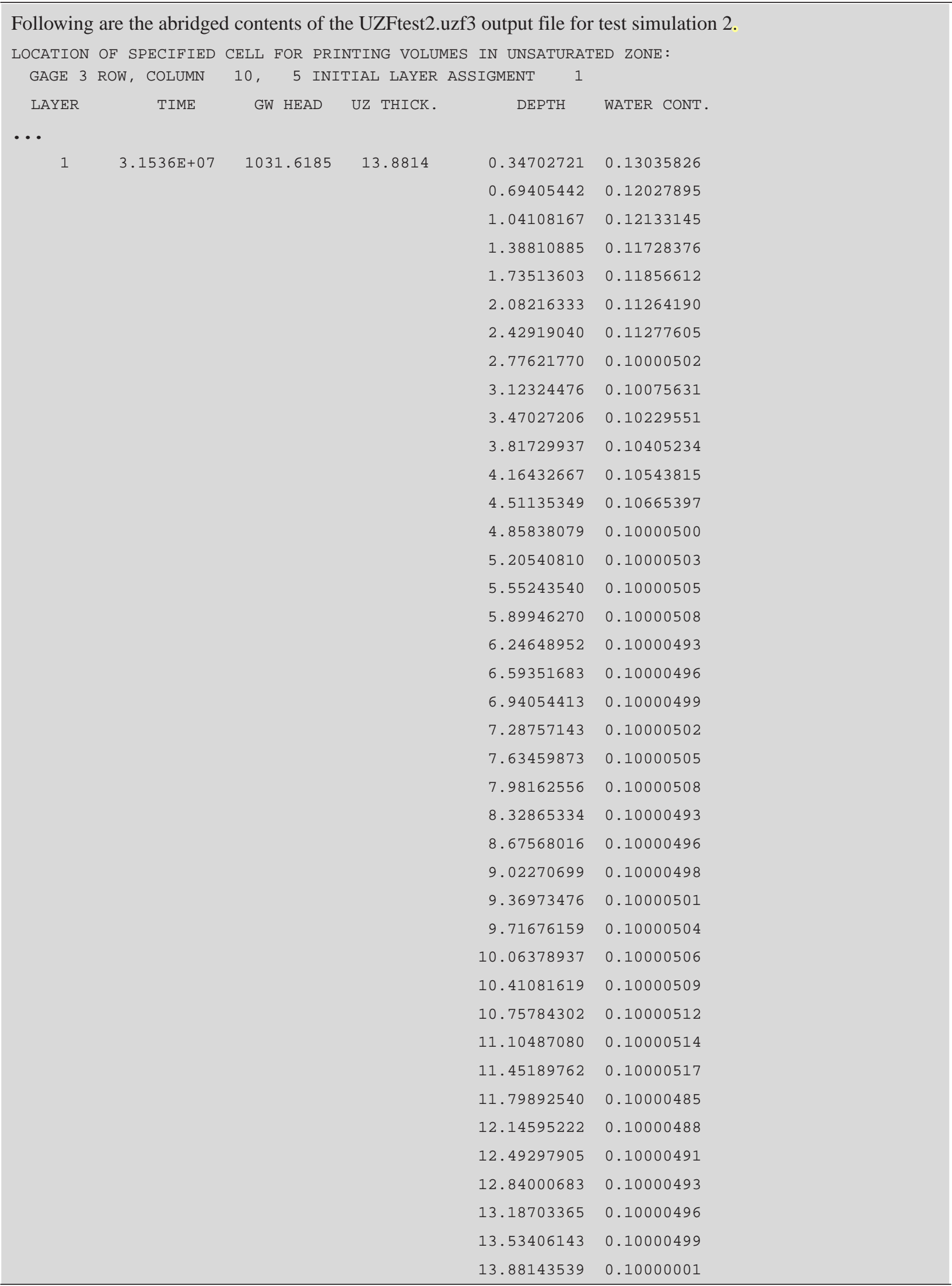




\begin{tabular}{|c|c|c|c|c|c|c|c|c|}
\hline \multirow[t]{2}{*}{ UNSATURATEI } & \multicolumn{8}{|c|}{ D MASS BALANCE COMPONENTS FOR ENTIRE MODEL } \\
\hline & \multicolumn{2}{|c|}{ APPLIED } & \multirow{2}{*}{$\begin{array}{l}\text { ACTUAL } \\
\text { INFILT. }\end{array}$} & \multicolumn{2}{|l|}{ SURFACE } & ET & \multicolumn{2}{|l|}{ UZ STORAGE } \\
\hline TIME & INFILT. & RUNOFF & & LEAKAGE & $\mathrm{UZ}$ & GW & CHANGE & RECHARGE \\
\hline $2.62 \mathrm{E}+06$ & $8.47 \mathrm{E}+00$ & 0.0 & $8.47 \mathrm{E}+00$ & 0.0 & $0.00 \mathrm{E}+00$ & $2.04 \mathrm{E}+01$ & $0.00 \mathrm{E}+00$ & $8.47 \mathrm{E}+00$ \\
\hline $2.71 \mathrm{E}+06$ & $6.78 \mathrm{E}+01$ & 0.0 & $6.78 \mathrm{E}+01$ & 0.0 & $1.24 \mathrm{E}+02$ & $1.35 \mathrm{E}+01$ & $-6.64 \mathrm{E}+01$ & $9.70 \mathrm{E}+00$ \\
\hline $2.80 \mathrm{E}+06$ & $6.78 \mathrm{E}+01$ & 0.0 & $6.78 \mathrm{E}+01$ & 0.0 & $1.24 \mathrm{E}+02$ & $1.35 \mathrm{E}+01$ & $-6.63 \mathrm{E}+01$ & $9.61 \mathrm{E}+00$ \\
\hline \multicolumn{9}{|l|}{$\ldots$} \\
\hline $5.25 \mathrm{E}+06$ & $6.78 \mathrm{E}+01$ & 0.0 & $6.78 \mathrm{E}+01$ & 0.0 & $1.24 \mathrm{E}+02$ & $1.37 \mathrm{E}+01$ & $-6.55 \mathrm{E}+01$ & $9.04 \mathrm{E}+00$ \\
\hline $5.33 E+06$ & $8.47 E+01$ & 0.0 & $8.47 E+01$ & 0.0 & $1.24 \mathrm{E}+02$ & $1.38 \mathrm{E}+01$ & $-5.04 \mathrm{E}+01$ & $1.09 \mathrm{E}+01$ \\
\hline $5.42 E+06$ & $8.47 E+01$ & 0.0 & $8.47 E+01$ & 0.0 & $1.24 \mathrm{E}+02$ & $1.38 \mathrm{E}+01$ & $-5.04 \mathrm{E}+01$ & $1.09 \mathrm{E}+01$ \\
\hline \multicolumn{9}{|l|}{$\ldots$} \\
\hline $7.88 \mathrm{E}+06$ & $8.47 E+01$ & 0.0 & $8.47 E+01$ & 0.0 & $1.08 \mathrm{E}+02$ & $1.46 \mathrm{E}+01$ & $-3.97 E+01$ & $1.59 \mathrm{E}+01$ \\
\hline $7.96 \mathrm{E}+06$ & $1.69 \mathrm{E}+02$ & 0.0 & $1.69 \mathrm{E}+02$ & 0.0 & $1.04 \mathrm{E}+02$ & $1.47 \mathrm{E}+01$ & $4.93 E+01$ & $1.58 \mathrm{E}+01$ \\
\hline $8.05 E+06$ & $1.69 E+02$ & 0.0 & $1.69 \mathrm{E}+02$ & 0.0 & $1.04 \mathrm{E}+02$ & $1.47 \mathrm{E}+01$ & $4.93 E+01$ & $1.58 \mathrm{E}+01$ \\
\hline \multicolumn{9}{|l|}{$\cdots$} \\
\hline $1.05 E+07$ & $1.69 \mathrm{E}+02$ & 0.0 & $1.69 \mathrm{E}+02$ & 0.0 & $9.15 \mathrm{E}+01$ & $1.54 \mathrm{E}+01$ & $5.22 \mathrm{E}+01$ & $2.57 \mathrm{E}+01$ \\
\hline $1.05 E+07$ & $4.23 E+01$ & 0.0 & $4.23 E+01$ & 0.0 & $9.25 \mathrm{E}+01$ & $1.55 \mathrm{E}+01$ & $-7.44 \mathrm{E}+01$ & $2.43 E+01$ \\
\hline $1.06 \mathrm{E}+07$ & $4.23 E+01$ & 0.0 & $4.23 E+01$ & 0.0 & $9.30 \mathrm{E}+01$ & $1.55 \mathrm{E}+01$ & $-7.47 \mathrm{E}+01$ & $2.40 \mathrm{E}+01$ \\
\hline \multicolumn{9}{|l|}{$\cdots$} \\
\hline $1.31 \mathrm{E}+07$ & $4.23 E+01$ & 0.0 & $4.23 E+01$ & 0.0 & $6.10 \mathrm{E}+01$ & $1.84 \mathrm{E}+01$ & $-2.66 \mathrm{E}+01$ & $7.97 \mathrm{E}+00$ \\
\hline $1.32 \mathrm{E}+07$ & $8.47 E+01$ & 0.0 & $8.47 E+01$ & 0.0 & $6.18 \mathrm{E}+01$ & $1.83 E+01$ & $1.49 \mathrm{E}+01$ & $8.04 E+00$ \\
\hline $1.33 E+07$ & $8.47 E+01$ & 0.0 & $8.47 E+01$ & 0.0 & $6.21 \mathrm{E}+01$ & $1.83 E+01$ & $1.44 \mathrm{E}+01$ & $8.13 E+00$ \\
\hline \multicolumn{9}{|l|}{$\ldots$} \\
\hline $1.57 \mathrm{E}+07$ & $8.47 E+01$ & 0.0 & $8.47 E+01$ & 0.0 & $6.76 \mathrm{E}+01$ & $1.81 \mathrm{E}+01$ & $-1.65 \mathrm{E}+00$ & $1.88 \mathrm{E}+01$ \\
\hline $1.58 \mathrm{E}+07$ & $2.54 \mathrm{E}+01$ & 0.0 & $2.54 \mathrm{E}+01$ & 0.0 & $6.78 \mathrm{E}+01$ & $1.81 \mathrm{E}+01$ & $-6.00 \mathrm{E}+01$ & $1.76 \mathrm{E}+01$ \\
\hline $1.59 \mathrm{E}+07$ & $2.54 \mathrm{E}+01$ & 0.0 & $2.54 \mathrm{E}+01$ & 0.0 & $6.79 \mathrm{E}+01$ & $1.81 \mathrm{E}+01$ & $-6.01 \mathrm{E}+01$ & $1.75 \mathrm{E}+01$ \\
\hline \multicolumn{9}{|l|}{$\cdots$} \\
\hline $1.83 E+07$ & $2.54 \mathrm{E}+01$ & 0.0 & $2.54 \mathrm{E}+01$ & 0.0 & $6.91 \mathrm{E}+01$ & $1.80 \mathrm{E}+01$ & $-5.28 \mathrm{E}+01$ & $9.20 \mathrm{E}+00$ \\
\hline $1.84 \mathrm{E}+07$ & $4.23 E+01$ & 0.0 & $4.23 E+01$ & 0.0 & $6.89 \mathrm{E}+01$ & $1.80 \mathrm{E}+01$ & $-3.53 E+01$ & $8.83 E+00$ \\
\hline $1.85 \mathrm{E}+07$ & $4.23 E+01$ & 0.0 & $4.23 E+01$ & 0.0 & $6.89 \mathrm{E}+01$ & $1.80 \mathrm{E}+01$ & $-3.57 \mathrm{E}+01$ & $9.19 \mathrm{E}+00$ \\
\hline \multicolumn{9}{|l|}{$\ldots$} \\
\hline $2.10 \mathrm{E}+07$ & $4.23 \mathrm{E}+01$ & 0.0 & $4.23 E+01$ & 0.0 & $6.67 \mathrm{E}+01$ & $1.80 \mathrm{E}+01$ & $-3.53 E+01$ & $1.09 \mathrm{E}+01$ \\
\hline $2.11 \mathrm{E}+07$ & $2.54 \mathrm{E}+01$ & 0.0 & $2.54 \mathrm{E}+01$ & 0.0 & $6.67 \mathrm{E}+01$ & $1.80 \mathrm{E}+01$ & $-5.07 \mathrm{E}+01$ & $9.37 \mathrm{E}+00$ \\
\hline $2.11 \mathrm{E}+07$ & $2.54 \mathrm{E}+01$ & 0.0 & $2.54 \mathrm{E}+01$ & 0.0 & $6.67 \mathrm{E}+01$ & $1.80 \mathrm{E}+01$ & $-5.06 \mathrm{E}+01$ & $9.31 \mathrm{E}+00$ \\
\hline \multicolumn{9}{|l|}{$\ldots$} \\
\hline $2.36 \mathrm{E}+07$ & $2.54 \mathrm{E}+01$ & 0.0 & $2.54 \mathrm{E}+01$ & 0.0 & $5.77 \mathrm{E}+01$ & $1.82 \mathrm{E}+01$ & $-4.34 \mathrm{E}+01$ & $1.11 \mathrm{E}+01$ \\
\hline $2.37 E+07$ & $1.69 \mathrm{E}+01$ & 0.0 & $1.69 \mathrm{E}+01$ & 0.0 & $5.76 \mathrm{E}+01$ & $1.82 \mathrm{E}+01$ & $-5.36 \mathrm{E}+01$ & $1.29 \mathrm{E}+01$ \\
\hline $2.38 \mathrm{E}+07$ & $1.69 \mathrm{E}+01$ & 0.0 & $1.69 \mathrm{E}+01$ & 0.0 & $5.75 \mathrm{E}+01$ & $1.82 E+01$ & $-5.34 \mathrm{E}+01$ & $1.28 \mathrm{E}+01$ \\
\hline \multicolumn{9}{|l|}{$\cdots$} \\
\hline $2.62 E+07$ & $1.69 \mathrm{E}+01$ & 0.0 & $1.69 \mathrm{E}+01$ & 0.0 & $5.20 \mathrm{E}+01$ & $1.86 \mathrm{E}+01$ & $-4.71 \mathrm{E}+01$ & $1.21 \mathrm{E}+01$ \\
\hline $2.63 E+07$ & $8.47 E+00$ & 0.0 & $8.47 E+00$ & 0.0 & $5.07 \mathrm{E}+01$ & $1.86 \mathrm{E}+01$ & $-5.21 \mathrm{E}+01$ & $9.86 \mathrm{E}+00$ \\
\hline $2.64 \mathrm{E}+07$ & $8.47 \mathrm{E}+00$ & 0.0 & $8.47 \mathrm{E}+00$ & 0.0 & $5.04 \mathrm{E}+01$ & $1.87 \mathrm{E}+01$ & $-5.17 \mathrm{E}+01$ & $9.77 \mathrm{E}+00$ \\
\hline \multicolumn{9}{|l|}{$\ldots$} \\
\hline $3.09 \mathrm{E}+07$ & $8.47 \mathrm{E}+00$ & 0.0 & $8.47 \mathrm{E}+00$ & 0.0 & $3.03 E+01$ & $1.95 \mathrm{E}+01$ & $-3.09 \mathrm{E}+01$ & $9.03 E+00$ \\
\hline $3.12 \mathrm{E}+07$ & $8.47 E+00$ & 0.0 & $8.47 \mathrm{E}+00$ & 0.0 & $2.99 \mathrm{E}+01$ & $1.96 \mathrm{E}+01$ & $-3.15 \mathrm{E}+01$ & $9.82 \mathrm{E}+00$ \\
\hline $3.15 \mathrm{E}+07$ & $8.47 \mathrm{E}+00$ & 0.0 & $8.47 E+00$ & 0.0 & $2.95 \mathrm{E}+01$ & $1.96 \mathrm{E}+01$ & $-3.24 \mathrm{E}+01$ & $1.12 \mathrm{E}+01$ \\
\hline
\end{tabular}


Manuscript approved for publication, January 6, 2006

Prepared by the U.S. Geological Survey Publishing Staff, Publishing Service Center, Tacoma, WA

Linda Rogers

Sharon Wahlstrom

Bobbie Jo Richey

Publishing Service Center, Salt Lake City, UT

Angelia M. Thacker

For more information concerning the research in this report, contact the

Director, Nevada Water Science Center

U.S. Geological Survey

2730 North Deer Run Road

Carson City, NV 89701

http://nv.water.usgs.gov 
